4 norden 



\section{Risk assessment and risk management of novel plant foods}

Concepts and principles

Ib Knudsen, Inge Søborg, Folmer Eriksen, Kirsten Pilegaard and Jan Pedersen.

TemaNord 2005:588 
Risk assessment and risk management of novel plant foods

Concepts and principles

TemaNord 2005:588

(C) Nordic Council of Ministers, Copenhagen 2005

ISBN 92-893-1251-3

Print: Ekspressen Tryk \& Kopicenter

Cover photo: Dr. Michael Hermann

Copies: 400

Printed on environmentally friendly paper

This publication can be ordered on www.norden.org/order. Other Nordic publications are available at www.norden.org/publications

Printed in Denmark

Nordic Council of Ministers

Store Strandstræde 18

DK-1255 Copenhagen K

Phone (+45) 33960200

Fax (+45) 33960202

www.norden.org

\section{Nordic Council}

Store Strandstræde 18

DK-1255 Copenhagen K

Phone (+45) 33960400

Fax (+45) 33111870

\section{Det nordiske levnedsmiddelsamarbejde}

Nordisk Embedsmandskomité for Levnedsmiddelspørgsmål (EK-LIVS) arbejder med principielle levnedsmiddelpolitiske spørgsmål vedrørende kost og ernæring, levnedsmiddeltoksikologi og mikrobiologi bl.a. i relation til risikovurdering, levnedsmiddelkontrol og -lovgivning. Samarbejdet sigter på beskyttelse af forbrugernes sundhed, fælles udnyttelse af faglige og administrative ressourcer samt nordisk og international udvikling af fagområderne.

\section{Nordic co-operation}

Nordic co-operation, one of the oldest and most wide-ranging regional partnerships in the world, involves Denmark, Finland, Iceland, Norway, Sweden, the Faroe Islands, Greenland and Åland. Cooperation reinforces the sense of Nordic community while respecting national differences and similarities, makes it possible to uphold Nordic interests in the world at large and promotes positive relations between neighbouring peoples.

Co-operation was formalised in 1952 when the Nordic Council was set up as a forum for parliamentarians and governments. The Helsinki Treaty of 1962 has formed the framework for Nordic partnership ever since. The Nordic Council of Ministers was set up in 1971 as the formal forum for co-operation between the governments of the Nordic countries and the political leadership of the autonomous areas, i.e. the Faroe Islands, Greenland and Åland. 


\section{Contents}

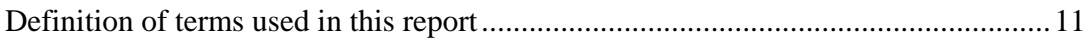

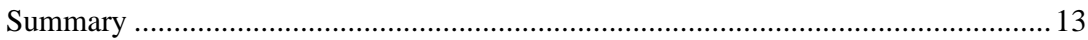

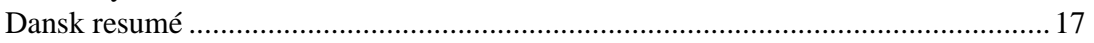

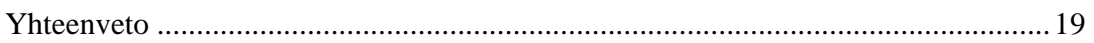

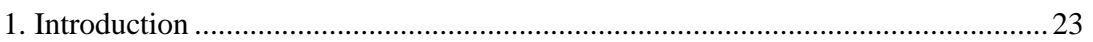

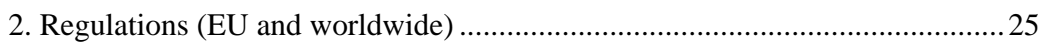

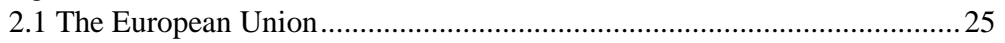

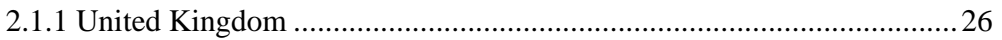

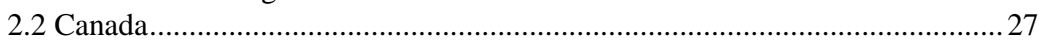

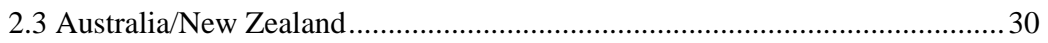

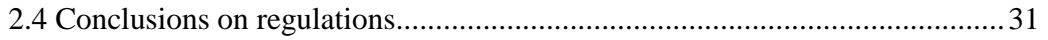

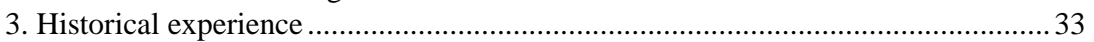

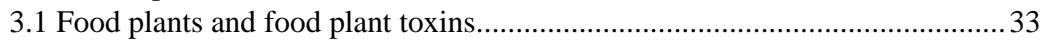

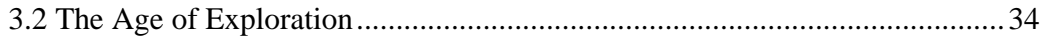

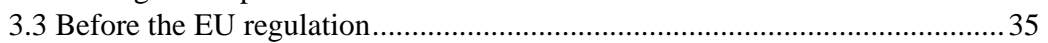

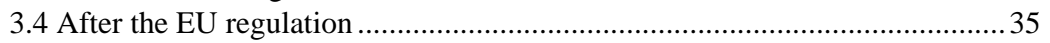

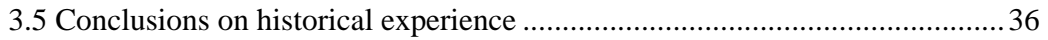

4. Examples - past and present............................................................................. 37

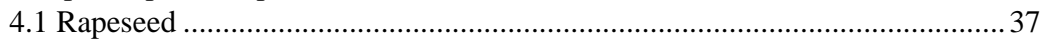

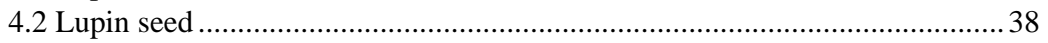

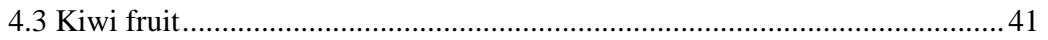

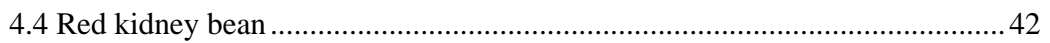

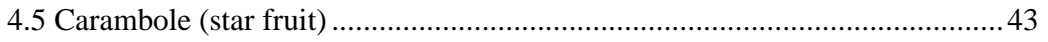

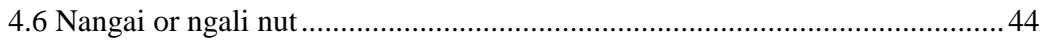

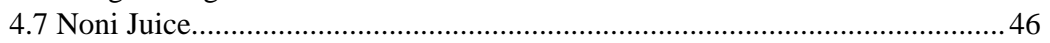

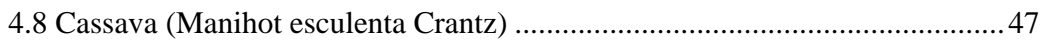

4.9 Conclusions on experiences from past and present cases ..................................48

5. Potential for new, novel plant foods to be introduced on the EU market.................51

5.1 Conclusions on the potential for novel plant foods to be introduced in

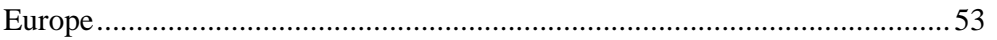

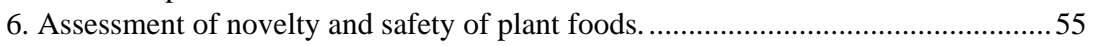

6.1 Determination of novelty of the plant food as part of the establishment

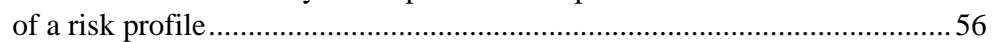

6.2 Establishment of a risk assessment policy for conduct of the scientific risk

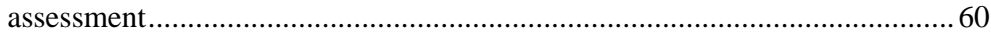

6.3 Conclusions on the assessment of novelty and safety.....................................64

7. Different tools applicable for premarket analysis .....................................................65

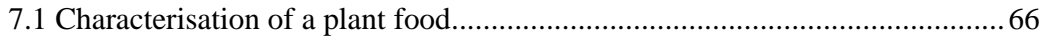

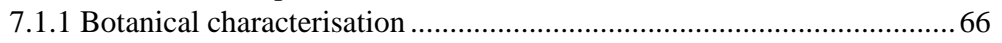

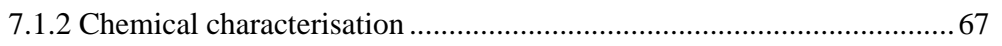

7.2 History of use as food................................................................................ 70

7.3 Animal studies in the safety testing of novel plant foods ............................... 73

7.4 Testing of novel foods in in vitro tests for toxicity and mutagenicity ............. 75

7.5 Test of novel foods for allergenicity .............................................................. 76

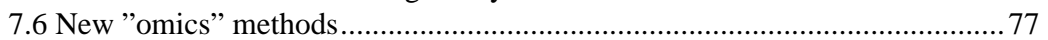

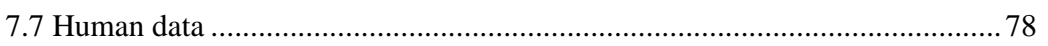

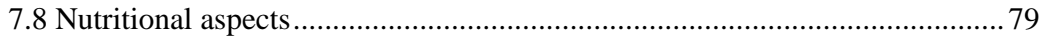

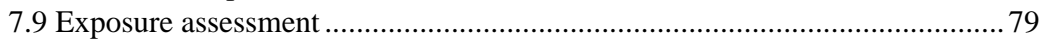

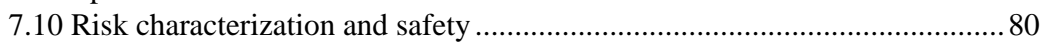

7.11Conclusions on tools applicable for premarket analysis ................................ 81 
8. A plea for a continued interactive exchange of concepts and ideas between management and science in this field

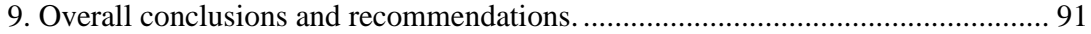

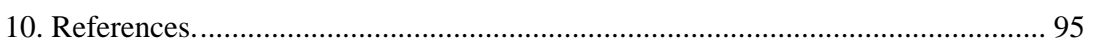

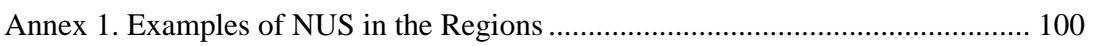

Annex 2. Draft global list based on the FAO-list of global plant food production... 103

Annex 3. Draft regional plant list based on the NETTOX food plant list. ......

106 


\section{Preface}

The Nordic Committee of Senior Officials for Food Issues is a body under the Nordic Council of Ministers co-ordinating Nordic work in the field of foods. The Nordic Working Group on Food Toxicology and Risk Evaluation (NNT) has been given the responsibility by the Committee to promote co-operation and co-ordination among Nordic countries in matters relating to food toxicology and risk assessment.

Under this working group a project group was funded and established with the aim to discuss different aspects of defining, regulating and evaluating whole foods derived from plants with no or limited documented history of safe consumption and to propose a strategy for the safety assessment of these foods. This work was originally proposed to be part of the OECD Task Force Group for the Safety of Novel Foods and Feeds, with the Nordic project group as the leading "country". The OECD Task Force Group decided not to take this work into its work programme for the moment but use the final Nordic report for its decision on future activities in this area in the Task Force Group.

The project group consisted of the following members:

\begin{tabular}{|c|c|c|}
\hline Jan Pedersen & Danish Institute for Food and & Denmark \\
\hline Ib Knudsen & $\begin{array}{l}\text { Danish Institute for Food and } \\
\text { Veterinary Research }\end{array}$ & Denmark \\
\hline Folmer D. Eriksen & $\begin{array}{l}\text { Danish Institute for Food and } \\
\text { Veterinary Research }\end{array}$ & Denmark \\
\hline Inge Søborg & $\begin{array}{l}\text { Danish Institute for Food and } \\
\text { Veterinary Research }\end{array}$ & Denmark \\
\hline Leena Mannonen & Ministry of Trade and Industry & Finland \\
\hline Christer Andersson & National Food Administration & Sweden \\
\hline Arne Mikalsen & $\begin{array}{l}\text { Norwegian Scientific } \\
\text { Committee for Food Safety }\end{array}$ & Norway \\
\hline
\end{tabular}

The report has been compiled and prepared by Ib Knudsen, Inge Søborg, Folmer Eriksen, Kirsten Pilegaard and Jan Pedersen.

In order to bring in a worldwide perspective on the subject an international workshop was arranged to discuss a draft report. This Workshop was held in Copenhagen 18-19 May 2005. The participants in the workshop were all invited to present their background and personal view on 
the situation and bring useful information and new ideas to the Nordic project group.

Invited persons for the workshop:

Nora Lee

Leanne Laajoki

Marten Sørensen

Kirsten Pilegaard

Jørn Gry

Morten Poulsen

Heddie Mejborn

Hanne Boskov

Hansen

Jiri Ruprich

Michael Hermann

Mar Gonzalez

Päivi Mannerkorpi

DG SANCO

Health

Directorate
Canada

Australia New Zealand (FSANZ)

The Royal Veterinary and

Denmark Agricultural University

Institute for Food and

Denmark

Veterinary Research

Institute for Food and

Veterinary Research

Institute for Food and

Denmark

Veterinary Research

Institute for Food and

Denmark

Veterinary Research

Danish Veterinary and Food

Denmark

Administration

National Institute of Public

Czech Republic

IPGRI-Colombia

Colombia

OECD, Environment

France

Belgium

Karl-Heinz Engel $\quad$ EFSA

Italy 
Samuel W. Page WHO Switzerland

NNT is responsible for the text of the report and its conclusions and recommendations.

The report has been reviewed and accepted by NNT in September 2005 . 



\section{Definition of terms used in this report}

- Foods: Foods and food ingredients.

- Plants: Conventional plants meaning cultivated plants without use of gene technology, and plants from wild sources.

- Plant foods: Products used as food with a plurality of chemical constituents in a complex, holistic interplay ranging from intact fruits and vegetables, over complex botanical products like flour and botanical extracts to oils, fibres and proteins. Distinct from pure chemicals with only one chemical entity as the building block.

- Traditional foods: Foods with a history of significant human consumption by the broad community for several generations as part of the ordinary diet and thereby generally recognised as safe at the global, regional or local level or by an ethnic group.

- Non-traditional foods: Foods with no history of significant human consumption by the broad community for several generations as part of the ordinary diet.

- Novel foods: Non-traditional foods for which there is insufficient knowledge in the broad community to ensure safe use, or which have characteristics that raise safety concerns due to composition, levels of undesirable substances, potential for adverse effects, traditional preparation and cooking, and patterns and levels of consumption.

- Global list of traditional food plants: A list of plants, identifiable by name and delivering specified plant material used for traditional foods at the global level.

- Regional lists of traditional food plants: A set of lists with plants delivering plant material used for traditional foods at the regional level covered by the individual list. "The Region" may be defined on the basis of the five regional dietary patterns described by WHO/FAO in GEMS (WHO, 2003): Middle Eastern, Far Eastern, African, Latin American and European (incl. Australia, Canada and the USA), or as economical or regulatory entities like EU or Australia/New Zealand. When finalised the lists should cover all geographical regions of the world, thereby supplementing each other.

- Local lists of traditional food plants: Lists with plants delivering plant material used for traditional foods at the local level. A "Local lists" could cover EU, or individual nations like Denmark and China, or an area with a human population of mixed ethnic origin within a region or nation. 
- Ethnobotanical lists of traditional food plants: Individual lists with plants delivering plant material used for traditional foods by individual ethnical groups. "Ethnobotanical lists" are lists developed to cover well established plant food eating habits of a defined ethnic entity, e.g. aboriginals in Australia.

- History of use: Relevant data for history of use is characterisation of the plant species and composition of the food item, collection of information regarding historical evidence for food use, possible adverse effects as well as other characteristic effects in humans, cultivation/harvesting, processing and preparation methods, amount to be eaten.

- History of safe use for a food: Term used for the qualified presumption of safety making the food generally recognised as safe in the community. The evidence for safety of the food derives from compositional data and from experience since the food has been an ongoing part of the diet for a number of generations in a large, genetically diverse population in that community. This presumption is for a certain context of use (conditions of use, defined part of the plant used and required processing) and allows for minor population predispositions such as intolerance and allergenicity. 


\section{Summary}

Around 30 food plants deliver 95\% of human daily intake of plant food calories on a worldwide basis. In Europe the last 5 percentages of the daily plant food calory intake, herbs, etc. is delivered by roughly 300 other plant species. Both the 30 and the 300 plants have the potential to deliver novel food items from plant parts which not hitherto have been used in the human food supply but the major potential source for novel plant foods is the nearly 7000 other plant species traditionally used in the human food supply in other parts of the world. This report focuses on the situation when novel food items from these 7000 plants are to enter the European market.

The historical experience as well as experiences from past and present introductions of new plant foods in Europe like rapeseed, lupin seed, kiwi fruit, red kidney bean, carambole, nangai nut, noni juice and cassava are analysed with the conclusion that some novel plant foods, like cassava, may need special attention when introduced in countries and regions, where there is no tradition for their use.

The report takes its starting point in the novel food regulation already in force in the European Communities, Australia/New Zealand and Canada. The legislation in all three places distinguishes between the traditional plant foods on one side and the novel plant foods on the other side because the novel plant foods need to go through a premarket assessment procedure. Since this regulation is pretty new, the EU legislation from 1997, the managerial and scientific instruments for the enforcement of this regulation are still under development.

On this background the present report has developed a proposal for a set of definitions and criteria for determining if a plant food is traditional or novel and a proposal for an approach for the safety assessment of such plant foods with no or limited documented history of safe consumption.

The Nordic Working Group recommends to introduce:

- The use of a 2-step management procedure, first to establish the novelty and secondly to define and commit resources for the safety assessment, and

- The use of a worldwide net of global, regional, local and ethnobotanical positive lists for food plants to guide the decision on novelty at the first step and to enable the safety assessment at the second step. 
At the first step of the 2-step management procedure the management should establish a risk profile with the input from stakeholders, scientists in the field and consumer representatives taking into account the product itself, information on expected intake, history of use, values at risk, e.g. human health, economy, other potential consequences, consumer perception of risks and benefits, and societal distribution of risks and benefits. The plant lists discussed below are an integrated element of the history of use. The discussions at this step should lead to the conclusion whether the plant food under consideration is traditional at the regional level or local level or a traditional ethnic food in the area, or actually a novel plant food, which needs a safety assessment according to the regulation.

At the second step of the 2-step management procedure the management decides on a general risk assessment policy for all plant foods defined as novel foods at the first step. The risk assessment policy defines the extent and sequence of the scientific data, which should be made available for the scientific risk assessors for the premarket assessment.

For a smooth introduction of the so-called exotic fruits and vegetables from one region to another the NNT recommends to use the "history of use"-concept as the core ingredient of the premarket submission. To the extent that the data submitted by the applicant can support the claim that a product has a history of safe use, the submission can be approved.

To support and ease the availability of a high quality "history of use" data set for the premarket submissions the NNT recommends the development of a worldwide net of positive lists of food plants recognizing the plants as sources of foods either at the global level, at different regional levels or local levels or known as ethnobotanical foods in different places. The individual lists should reflect the use of plant foods in the region, at the local level or the ethnobotanical setting, where they are developed. When all of them are available, they should create a complete worldwide picture of the use of plant foods. The expectation of the NNT is that the combined use of data from all these lists will facilitate the mutual acceptance of safety and benefits of plant foods and plant food ingredients across political, economical and cultural borders. The NNT recommends that all lists should be developed after the internationally agreed principles and build on the internationally agreed criteria to become mutually acceptable, e.g. in WTO, and stresses that all the lists should be based upon reliable, high quality information and proper reference sources in order to meet the acceptance of critical scientific assessors.

The report gives recommendations in an area of the food safety arena, where there is still very little scientific experience. All concepts are very new, and the principles are not fixed by regulatory traditions yet. Therefore the NNT strongly recommends continued interactive exchanges of concepts and ideas between management and science in this field both 
horizontally and vertically to ensure that the best legal and scientific instruments for the work will be chosen. 



\section{Dansk resumé}

Omkring 30 fødevareplanter bidrager med ca. 95\% af det daglige kalorie indtag fra planter på verdens basis. I Europa kommer de sidste 5\% af kalorie indtaget rundt regnet fra 300 andre planter. Både de 30 og de 300 planter har potentialet til at levere nye fødevarer fra plantedele der ikke hidtil har været anvendt til fødevarer, men det største potentiale, som kilde til nye fødevareplanter, er de omkring 7000 andre plantearter der anvendes andre steder i verden som fødevarer. Denne rapport fokuserer på den situation hvor nye fødevareprodukter fra disse ca. 7000 plantearter er på vej til det Europæiske marked.

Den historiske og nuværende erfaring med introduktion af nye plantefødevarer i Europa som f.eks. raps, lupinfrø, kiwi, rød have-bønne, stjernefrugt, nangai nød, noni juice og cassava bliver analyseret med den konklusion at nogle nye plantefødevarer som f.eks. cassava (maniok) bør have speciel opmærksomhed når de introduceres i lande eller regioner hvor der ikke er tradition for deres anvendelse.

Rapporten tager udgangspunkt i de reguleringer af nye fødevarer som findes i EU, Australien/New Zealand og Canada. Lovgivningerne skelner alle tre steder mellem traditionelle fødevarer på den ene side og nye fødevarer på den anden side, hvor de nye fødevarer skal gennemgå en vurdering før de kan markedsføres. Fordi disse reguleringer er forholdsvise nye (EU reguleringen er fra 1997) er både de administrative og videnskabelige redskaber stadig under udvikling.

På denne baggrund leverer denne rapport forslag til definitioner og kriterier for bestemmelse om en fødevareplante er traditionel eller ny og foreslår en arbejdsmetode for den faglige risikovurdering af nye plantefødevarer hvor der er begrænsede eller ingen erfaring med deres anvendelse som fødevare.

Den Nordiske Arbejdsgruppe anbefaler at introducere:

- En 2 trins håndteringsprocedure, hvor der først tages stilling til om produktet et nyt eller traditionelt og derefter definerer behovet og omfanget af den faglige risikovurdering.

- Brugen af et verdensomspændende net af globale, regionale, lokale og etnobotaniske positiv lister med fødevareplanter til brug for beslutningen i første trin om et produkt er nyt og til at fastlægge behovet for og hjælpe til den faglige risikovurdering i andet trin.

I det første trin af 2-trins håndteringsproceduren bør der etableres en risiko profil med input fra interessenter, fagfolk på området og forbruger repræsentanter med hensyntagen til selve produktet, forventet størrelse af 
indtag, history of use (erfaringer med anvendelsen), værdier på spil f.eks. sundhed, økonomi og andre potentielle konsekvenser, forbrugernes opfattelse af risiko og fordele samt den sociale fordeling af risiko og fordele. De plantelister der diskuteres nedenfor er en integreret del af history of use. På dette trin bør diskussionen føre til en konklusion om planteproduktet skal betragtes som traditionelt på regionalt eller lokalt niveau eller betragtes som en etnisk fødevare eller som en ny fødevare hvor der kræves en risikovurdering ifølge reguleringen.

For alle planteprodukter der defineres som nye på første trin tages beslutning på 2. trin om den generelle risikovurderings procedure. Den generelle risikovurderings procedure skal således definere omfanget og følgen af de videnskabelige data som skal være til rådighed for den faglige risikovurdering af produktet.

For at gøre det lettere at introducere de såkaldte eksotiske frugter og grønt fra en region til en anden, anbefaler NNT at bruge konceptet history of use som en vigtig del af ansøgningen om markedsføring. I det omfang en ansøger kan fremvise data som støtter at et produkt har en history of safe use (historisk sikker anvendelse) kan godkendelse gives.

For at støtte og lette tilgængeligheden af en høj kvalitet af "history of use” data til en ansøgning om markedsføring foreslår NNT udvikling af et verdensomspændende net af positive lister for planter som er kilde til fødevarer på enten globalt niveau, på forskelligt regionalt eller lokalt niveau eller kendt som etnisk fødevare forskellige steder. De individuelle lister skal reflektere anvendelsen af fødevareplanter i regionen, lokalt eller de etnobotaniske områder planterne stammer fra.

Når alle lister er tilgængelige vil de give et samlet billed af verdens anvendte fødevareplanter. Forventningen hos NNT er at denne samlede datamængde fra disse lister vil gøre det lettere gensidigt at acceptere sikkerheden og fordelene af disse fødevareplanter på tværs af politiske, økonomiske og kulturelle grænser. NNT anbefaler at alle listerne udvikles efter internationale anerkendte principper og bygger på internationale anerkendte kriterier for at blive gensidigt accepterede, f.eks. i WTO regi, og fremhæver at listerne baseres på information fra kilder som er troværdige og passende og i høj kvalitet således, at det kan blive accepteret ved en kritisk videnskabelig vurdering.

Rapporten giver anbefalinger indenfor fødevaresikkerheds området, hvor der stadig er begrænset videnskabelig viden. Alle koncepterne er relativt nye og principperne er endnu ikke fikseret af regulatoriske traditioner. Derfor anbefaler NNT stærkt at fortsætte den interaktive udveksling af koncepter og ideer imellem aktører indenfor administration og videnskab i dette felt både horisontalt og vertikalt til at sikre, at de bedste regulerings og videnskabelige instrumenter vil blive anvendt. 


\section{Yhteenveto}

Maailmanlaajuisesti ihmisten päivittäinen energiasaanti kasveista tulee 95 prosenttisesti noin 30 elintarvikekasvista. Euroopassa loput 5\% päivittäisestä kasviperäisestä energiasta saadaan noin 300 kasvilajista mm. yrteistä. Sekä edellä mainitut merkitykselliset 30 että vähemmän merkitykselliset 300 kasvia voivat tarjota uusia elintarvikeaineksia kasvinosista, joita ei aiemmin ole käytetty elintarvikeketjussa. Merkittävin uusien elintarvikeainesten lähde on kuitenkin ne 7000 muuta kasvilajia, joita käytetään perinteisesti ihmisravintona muualla maailmassa. Tässä raportissa tarkastellaan tilannetta, jossa Euroopan markkinoille tarjotaan elintarvikkeita näistä 7000 kasvista.

Raportissa tarkastellaan sekä historiallista kokemusta elintarvikekasveista että kokemuksia ruokavalioomme tulleista aikaisemmista ja tuoreemmista uutuuksista kuten rapsi, lupiinin siemenet, kiwi hedelmä, punainen tarhapapu, karambola, nangai pähkinä, noni mehu ja kassava. Johtopäätöksenä todetaan, että joitakin uusia kasvipohjaisia elintarvikkeita, esimerkiksi kassavaa, tulisi tarkastella lähemmin silloin, kun niitä saatetaan markkinoille maissa tai alueilla, joissa puutuu perinteinen käyttökokemus.

Raportissa lähdetään Euroopan yhteisössä, Australiassa/UudessaSeelannissa ja Kanadassa voimassa olevista uuselintarvikeasetuksista. Kaikissa kolmessa tapauksessa lainsäädäntö erottelee perinteiset kasviperäiset elintarvikkeet uusista, sillä uusien on läpäistävä markkinointilupaa edeltävä turvallisuusarvio. Koska lainsäädäntö on uutta, EU:ssa vasta vuodesta 1997 alkaen, sekä säädöksen toimintamuodot että tieteelliset periaatteet ovat vielä kehittymässä.

Tätä taustaa vasten raportissa on esitetty ehdotus kasvipohjaisten elintarvikkeiden uutuuden tai perinteisyyden määritelmistä ja määritelmien perusteista. Raportissa on myös esitetty ehdotus tavasta, jolla sellaisten kasviperäisten elintarvikkeiden turvallisuus voitaisiin arvioida, joista ei löydy kirjattua kokemusta turvallisesta elintarvikekäytöstä.

Pohjoismainen työryhmä suosittaa käyttöön:

Kaksivaiheista toimintamallia, jossa ensivaiheessa todennetaan uutuus ja toisessa vaiheessa määritellään turvallisuusarviotarve ja varataan siihen resurssit.

Hyödynnettäväksi maailmanlaajuista verkkoa maailmanlaajuisista, alueellisista, paikallisista ja kansantieteellis-kasvitieellisistä luetteloista koskien elintarvikekasveista. Tämä tieto auttaisi tehtäessä päätöksiä uutuudesta ja toisaalta se olisi apuna turvallisuusarviossa. 
Kaksivaiheisen toimintamallin ensimmäisessä vaiheessa riskinhallinnasta vastaavien tulisi muodostaa riski profiili (risk profile) yhteistyössä sidosryhmien, alan tiedemiesten ja kuluttajien edustajien kanssa. Työssä tulisi huomioida itse tuote, tieto arvioidusta käytöstä, aiempi käyttökokemus (history of use), asiaan liittyvä arvomaailma kuten ihmisten terveys, taloudelliset ja muut mahdolliset vaikutukset, kuluttajien hyväksyttävissä olevat riskit ja hyödyt sekä sosiaalinen riskien ja hyötyjen jakautuminen. Jäljempänä käsiteltävät kasviluettelot ovat oleellinen osa arvioitaessa aiempaa käyttökokemusta. Tässä käsittelyvaiheessa tulisi selvitetyksi onko kasviperäinen elintarvike perinteinen alueellisesti tai paikallisesti, onko se tietyllä alueella käytetty perinteinen etninen elintarvike vai onko se sellainen uusi kasviperäinen elintarvike, jolta edellytetään säädösten mukaista turvallisuuden arvioimista.

Kaksivaiheisen mallin toisessa vaiheessa riskinhallinnasta vastaavat päättävät yleisestä riskinarviossa omaksuttavasta asenteesta (risk assessment policy) kaikille ensi vaiheessa uusiksi määritellyille kasviperäisille elintarvikkeilla. Riskinarviossa omaksuttava asenne määrittelee sen tieteellisen aineiston laajuuden ja aineiston esittämisjärjestyksen, joka tulee saattaa tieteellistä riskinarviota suorittavien saataville markkinoille saattamista edeltävän arvioinnin suorittamiseksi.

Uutuuksien mahdollisimman sujuvan markkinoille saattamisen mahdollistamiseksi NNT suosittaa vierailta alueilta tulevien ns. eksoottisten hedelmien ja kasviksien lupahakemuksien perustaksi käsitettä "aiempi käyttökokemus". Tuote voidaan hyväksyä saatettavaksi markkinoille, mikäli hakemuksen tueksi jätetty aineisto vahvistaa tuotteen aiemman turvallisen käytön.

Jotta hakemusten tueksi olisi käytettävissä mahdollisimman helposti korkealuokkaista "aiempaa käyttökokemusta” tukevaa aineistoa suosittaa NNT kehitettäväksi maailmanlaajuista verkkoa elintarvikekasvien luetteloista. Luetteloihin kerättäisiin hyväksyttävää aineistoa kasveista valmistettujen elintarvikkeiden käytöstä maailmalaajuisesti, alueellisesti, paikallisesti tai kansantieteellisiin ja kasvitieteellisiin tietoihin pohjautuen. Yksittäisten luetteloiden tulisi kuvata kasviperäisen elintarvikkeen käyttöä sellaisilla alueilla tai paikoilla, joissa tuote on kehitetty elintarvikekäyttöön tai pohjaten kyseisten elintarvikekasvien kansantieteellisiin ja kasvitieteellisiin taustoihin. Kun kaikki luettelot on luotu, antaisivat ne maailmanlaajuisen näkemyksen kasviperäisten elintarvikkeiden käytöstä. NNT odottaa, että kaikista näistä luetteloista saatava tieto edesauttaisi yhteisymmärrystä turvallisuudesta ja kasviperäisten elintarvikkeiden tai elintarvikeainesten eduista yli poliittisten, taloudellisten tai kulttuuristen rajojen. NNT suosittaa, että nämä luettelot laadittaisiin kansainvälisesti sovittujen periaatteiden mukaisesti ja ne pohjautuisivat kansainvälisesti hyväksyttyihin periaatteisiin, jotta ne voitaisiin yhteisesti hyväksyä esimerkiksi WTO:ssa. NNT painottaa, että kaikkien luetteloiden tulisi perustua luotettavaan ja korkeatasoiseen tietoon ja hyväksyttäviin referenssiaineistoi- 
hin, jotta luettelot olisivat tieteellistä arviota tekevien asiantuntijoiden hyväksyttävissä.

Raportti antaa suosituksensa sellaisella elintarviketurvallisuuden osaalueella, jossa toistaiseksi on vielä hyvin vähän tieteellistä kokemusta. Kaikki esitetyt konseptit ovat hyvin uusia, eikä periaatteita ole sovittu säädöksin. Siksi NNT suosittaa vakavasti jatkuvaa vuorovaikutteista konseptien esittämistä ja ajatusten vaihtoa riskinhallinnasta vastaavien ja tieteen edustajien välillä, jotta voitaisiin varmistaa parhaan mahdollisen lainsäädännöllisen ja tieteellisen työkalun valinta. 



\section{Introduction}

This report deals with a segment of the novel foods, namely novel plant foods and novel plant food ingredients (hereinafter just named: novel plant foods), with the main focus on novel foods derived from plants not known in the country or region. The report does not deal with foods derived from genetically modified plants, but only foods derived from cultivated plants that may be developed through conventional breeding or plants from wild sources.

The aim is to develop a guide to the safety assessment of whole foods derived from plants with no or limited documented history of safe consumption in a country or region. For nearly all plant foods it is very difficult to obtain scientific data, which documents their history of safe consumption even if they have been eaten for several hundreds of years. Nevertheless according to the regulation of some countries there is a need to establish the safety of novel plant foods in order to accept their introduction in the market place.

The scope of this report is therefore to discuss principles and concepts for a safety assessment of novel plant foods, with a main focus on new exotic fruits and vegetables with no history of safe consumption, with the final aim to propose a procedure for safety assessment based upon up-todate scientific knowledge.

While there are well established ideas on how to address the safety assessments of isolated and extracted plant products, like sugars, fats and other defined chemical entities, there are no common international approaches to assess the safety of complex foods such as fruits, vegetables and other plant parts derived from novel sources.

During the last two decades a lot of attention has been paid to the safety assessment of genetically modified organisms (GMO) used as food. Several international reports have indicated that the safety assessment strategy recommended for genetically modified foods to a large extent also could be used for other kinds of novel foods. Another conclusion from many of these reports is that very little is known about the potential long-term health effects of any traditional food (e.g. FAO/WHO 2000). Nonetheless, most traditional foods are treated as being safe because no widespread occurrence of acute severe adverse effects is reported after their consumption. Their safety have, however, rarely, if ever, been established. One example could be coffee. A large fraction of the population is able to identify at least some acute adverse effects but most people handle coffee as being safe to consume. Another conclusion from the experience with genetically modified plants is that such plants have been thoroughly assessed for their safety prior to marketing, which 
is not the case for many other new whole foods. While it has been commonly accepted that for example food additives and pesticides should be thoroughly tested prior to being used or allowed in food production to secure that their level in the final food product would not constitute a health risk, foods from new plant lines or new exotic fruits and vegetables have not been evaluated to the same extent for potential adverse effects on health although there are several examples of risks connected to such foods (see chapter 4 ).

Considering fruits and vegetables with no history of safe use there is a need for identifying potential safety issues. It is also important to identify the type of information which would be useful for a safety assessment of such foods, and which type of analysis or tests, if any, that might be required to obtain the information before marketing.

Today countries such as Canada and Australia/New Zealand as well as the European Union (EU) have regulations for novel foods. The definition of what constitutes a novel food varies, but in common these regulations requires a pre-market safety assessment of such foods. However, the scientific guidelines for performing risk assessments of novel foods are in general poorly harmonised and are still developing as more and more attention is paid to these foods and more experience about testing methodology are obtained. Therefore, it would be very helpful to develop a common understanding of how such a safety assessment could be carried out based on present day knowledge. Our previous experience from traditional breeding of food plants, as well as experience with introduction of new foods from exotic plants, and more recently the pre-market approval of novel foods, will also feed into this process of developing guidance for safety assessment of novel food plants.

Tightly connected to this issue is of course the definition of novel foods. The prerequisite for doing a safety assessment is the recognition of the food item as being novel within a regulatory framework. The definition of what constitutes a novel food is basically a management decision. This report will give some suggestions for an approach that might be useful for a management decision, which also illustrate the different roles of management and science in the process and underlines the need for keeping the two different sets of arguments apart.

The overall aim of this report is thus to facilitate the introduction of novel plant foods into the market place through a clear definition of the roles of risk management and risk assessment in the process by explaining what each part should do, and thereby bringing the harmonization process of safety assessments of exotic fruits and vegetables an important step further. 


\section{Regulations (EU and worldwide)}

The novel food regulations in the EU, Canada and Australia/New Zealand discussed below have been chosen as examples of regulations. UK is presented separately from EU due to its experience in safety assessments of a wide variety of novel foods prior to the introduction of the EU regulation. It is not expected that prolonging the presentation of regulations with those of other countries will add to a great extent to the perspectives in the assessment and management of novel plant foods.

\subsection{The European Union}

The EU Novel Food Regulation was enacted January 1997 and came into force on 15 May 1997 with the principal objectives to protect the functioning of the internal market within the Community, and to protect public health.

The first article of the EU-regulation: (EC) No 258/97 of the European Parliament and of the Council of 27 January 1997 defines novel food as foods and food ingredients which have not hitherto been used for human consumption to a significant degree within the Community and which fall under the following categories:

a. foods and food ingredients containing or consisting of genetically modified organisms within the meaning of Directive 90/220/EEC;

b. foods and food ingredients produced from, but not containing, genetically modified organisms;

c. foods and food ingredients with a new or intentionally modified primary molecular structure;

d. foods and food ingredients consisting of or isolated from microorganisms, fungi or algae;

e. foods and food ingredients consisting of or isolated from plants and food ingredients isolated from animals, except for foods and food ingredients obtained by traditional propagating or breeding practices and having a history of safe food use;

f. foods and food ingredients to which has been applied a production process not currently used, where that process gives rise to significant changes in the composition or structure of the foods or food ingredients which affect their nutritional value, metabolism or level of undesirable substances.

The original European Novel Food legislation focused mainly on genetically modified organisms (a and b above) but this part has now been detached from the Novel Food Regulation and included in the new EC regulation, No. 1829/2003, on genetically modified food and feed. The remaining part of the Novel Food Regulation (No. 258/97) will soon be 
revised. This report addresses only the plant part of category (e) of the remaining Novel Food Regulation.

The European Novel Food Regulation establishes a system for premarket approval of novel foods, which thus have to be subjected to a safety assessment before they are placed on the market in the Community. The legislation aims at providing the public with an assurance of the safety of novel foods. Before the Novel Food Regulation was put in place, such products did not have to go through a pre-marketing approval before being introduced on the market. Now applicants interested in placing a novel food on the European market have to submit an application to the competent authority of the member state where the product is first to be placed on the market, and send a copy of the request to the Commission. That competent authority is then responsible for performing a primary safety assessment.

When the Novel Food Regulation with its many different types of novel foods was in place, the scientific community was given the difficult task of addressing how the required safety assessment of these products should be performed. This question was addressed in a Commission Recommendation of July 1997 (97/618/EC) concerning the scientific aspects and the presentation of information necessary to support applications for the placing on the market of novel foods and novel food ingredients and the preparation of initial assessment reports under regulation EC No 258/97 of the European Parliament and of the Council (European Commission, 1997). It seems clear that these guidelines have been developed with special emphasis on novel foods produced by GMO or novel processes (categories a, b, and $f$ above) and less so with regard to novel foods resulting from traditional breeding or import of products from countries outside the EU.

\subsubsection{United Kingdom}

The national initiative about assessment of novel food in the United Kingdom is now subordinate to the regulations of the European Union but was initiated long before the introduction of European regulations in the novel food area in 1997.

In October 1988, the ministers of the Ministry of Health and the Ministry of Agriculture, Fisheries and Foods (MAFF) announced that the Advisory Committee on Irradiated and Novel Foods would be reconstituted as the Advisory Committee on Novel Foods and Processes (ACNFP) to reflect more accurately the rapidly developing area of food biotechnology. The Committee was established as an independent body of experts whose remit has been only slightly changed over the period 1988 to 2003 and which today is "to advise the central authorities responsible, in England, Scotland, Wales and Northern Ireland, respectively, on any matters relating to novel foods and novel food processes, including 
food irradiation, having regard where appropriate to the views of relevant expert bodies” (ACNFP, 2004).

The experience of ACNFP in making risk assessments of various types of novel foods such as quorn, lupins, quinoa and passion fruit seed oil can give valuable contributions to the discussion in this report. Examples of novel food risk assessments undertaken by the ACNFP can be found in their annual reports (ACNFP 1989-2004).

\subsection{Canada}

In Canada, novel foods must undergo a pre-market safety assessment. The regulation is part of the Food and Drug Regulations and was promulgated in November 1999. A guideline for safety assessment of novel foods was produced in 1994, i.e. prior to the regulations coming into force. This guideline is in the process of being revised and updated to reflect both the more recent regulations, international agreement reached on the conduct of food safety assessment of foods derived from recombinantDNA plants and microorganisms through Codex Alimentarius and advancements in knowledge and experience in the safety assessment of novel foods derived from plants and microorganisms. A draft that was issued for consultation may be consulted on the Health Canada website at www.novelfoods.gc.ca. The definition of novel food given in the 1994 guideline is superseded by that found in the regulation.

The Canadian Food and Drug Regulations (Health Canada 1999) states that "novel food means

a. a substance, including a microorganism, that does not have a history of safe use as a food;

b. a food that has been manufactured, prepared, preserved or packaged by a process that has not been previously applied to that food, and causes the food to undergo a major change; and

c. a food that is derived from a plant, animal or microorganism that has been genetically modified such that

- the plant, animal or microorganism exhibits characteristics that were not previously observed in that plant, animal or microorganism,

- the plant, animal or microorganism no longer exhibits characteristics that were previously observed in that plant, animal or microorganism, or

- one or more characteristics of the plant, animal or microorganism no longer fall within the anticipated range for that plant, animal or microorganism.” 
Also, "genetically modify" means, "to change the heritable traits of a plant, animal or microorganism by means of intentional manipulation". Therefore, traditional breeding, for example, could result in a novel food if it produced a plant modified as described in part (c) above.

The Canadian regulations require a pre-market notification of novel foods to Health Canada, the federal health department. The determination that something is novel is the first step and considered distinct from the safety assessment, which is second. The notification must contain a description of the novel food together with information respecting its development, details of the major change, if any, details of the method by which it is manufactured, prepared, preserved, packaged and stored, information respecting its intended use and directions for its preparation, information respecting its history of use as a food in a country other than Canada, if applicable, information relied on to establish that the novel food is safe for consumption and information respecting the estimated levels of consumption by consumers of the novel food. The pre-market notification application should also include the text of all labels to be used in connection with marketing of the novel food. Based on the premarket notification, the Director within 45 days after receiving the notification decides whether the information is sufficient to establish that the food is safe for consumption or if additional information of a scientific nature is necessary in order to assess the safety of the novel food. The Director has to assess the product within 90 days after receiving the additional information requested, and, if the novel food is established as safe for consumption, notify the manufacturer or importer in writing that the information is sufficient.

The Guidelines for the safety assessment of novel foods that were published in Canada in 1994 (Health Canada 1994) were developed largely to address the safety of GMO and novel processing technology. The revised guidelines will be much more comprehensive and provide guidance on the data that may be needed to support the safety of all types of novel foods derived from plants and microorganisms.

These guidelines take into consideration that a food, such as an exotic fruit or vegetable, that has not previously been sold to any significant extent in Canada may have a history of safe use elsewhere. It may suffice to demonstrate this history. The revised guidelines include a definition of history of safe use. This is as follows:

"A substance may be considered to have a history of safe use as a food if it has been an ongoing part of the diet for a number of generations in a large, genetically diverse human population where it has been used in ways and at levels that are similar to those expected or intended in Canada”. The fact that a product has had a history of use according to the above definition in a jurisdiction with a similar food safety system would increase the level of confidence in the evidence presented. The following 
information would be needed to support a claim that a product has a history of safe use:

- Historical evidence indicating ongoing, frequent consumption by a cross-section of the population where it has been used over several generations (i.e. 100 years). This evidence may be derived from various sources including, but not limited to, scientific publications and patents, non-scientific publications and books, cookbooks, books on the history of food culture, and/or affidavits from two or more independent, reputable authorities that include well-documented accounts of the way the food is used and how they know it has the history it does. Limited usage or short-term exposure would not be adequate to demonstrate a history of safe use.

- A declaration of any possible adverse effects linked to the food documented in its country of origin and/or a country where there is a high degree of consumption.

- A description of the standard methods of commercial and/or domestic processing and preparation for consumption.

- A description of how the food is cultivated or (if from wild sources) harvested.

- Amounts of the food that people are likely to consume in Canada, including typical serving sizes and expected frequency of consumption, at both average and extreme high consumption levels.

- Analysis of the composition of the food based on randomly selected, statistically valid samples. This analysis should include proximate data as well as amino acid profile, fatty acid profile, mineral and trace mineral composition and vitamin composition, as well as any nutrients, antinutrients and bioactive phytochemicals known to be of particular interest in the product. The analysis should pay special attention to the presence of compounds in the food, which may have implications for the health of any groups of the Canadian population (e.g. possible toxicants or allergens or unusually high levels of nutrients in the food source or final food product).

- Metabolism and/or gastrointestinal effects in humans.

The submission should include reliable, high quality information and reference sources. Anecdotal evidence will be given less weight than scientifically derived data. Information on the history of human exposure will be particularly important where there are traditional handling or cooking requirements for a food that is novel. This information will need to be made available to consumers in a consistent manner. A current example of this is the advice regarding the necessity for a minimum period of vigorous boiling when cooking various dried beans. 


\subsection{Australia/New Zealand}

In Australia and New Zealand novel foods are regulated by Standard 1.5.1 - Novel Foods of the Australia New Zealand Food Standards Code. The Standard was introduced in December 1999 and the prohibition of the sale of novel food, unless listed in a table in that Standard and in compliance with any conditions of use specified in that table, came into force from June 2001. The purpose of the Standard is to ensure that nontraditional foods, which have features or characteristics that raise safety concerns, will undergo a risk-based safety assessment before they are offered for retail sale for direct consumption in Australia and/or New Zealand. Novel foods are a subset of non-traditional food.

Standard 1.5.1 introduced December 1999 defines non-traditional food and novel food as follows:

- non-traditional food means a food which does not have a history of significant human consumption by the broad community in Australia or New Zealand.

- novel food means a non-traditional food for which there is insufficient knowledge in the broad community to enable safe use in the form or context in which it is presented, taking into account -

a) the composition or structure of the product; or

b) levels of undesirable substances in the product; or

c) known potential for adverse effects in humans; or

d) traditional preparation and cooking methods; or

e) patterns and levels of consumption of the product.

It is not specifically stated in the Standard whether or not it applies retrospectively. However, it is unlikely, though not impossible, that a product on the market in Australia and/or New Zealand prior to the introduction of the Standard would be considered to be 'non-traditional'.

Food Standards Australia New Zealand has developed two documents (FSANZ 2004a, 2004b) to assist in interpreting the Standard as follows:

- 'Format for applying to amend the Code - Novel Foods' which contains a template which can be used when making an application for permission to use a novel food (Attachment 2); and

- 'Guidelines to assist in applying to amend the Australia New Zealand Food Standards Code - Novel Foods' which provides details of the operation of the standard, descriptions of the likely categories of novel foods, a decision tree for determining the novelty of a food, data requirements for the assessment of novel foods and a record of views formed in response to inquiries with respect to novelty. 
The guidelines document was completely reviewed and updated in early 2004. A table presenting a record of views formed in response to inquiries with respect to novelty was included. The table presents the outcome view with respect to whether a particular food is: a) traditional or nontraditional; and b) novel or not novel, with respect to the definitions in Standard 1.5.1. Advice as to the potential novelty of the food is provided by the internal Novel Foods Reference Group. A final determination as to the novelty of a food is made in conjunction with relevant enforcement agencies.

For non-traditional foods, two steps may be necessary to meet the requirement of this Standard: an initial step to assess the novelty of the food, including identification of potential hazards connected to the food, and a second step to assess the safety of the novel food.

The guidelines document also lists some potential categories of novel foods, of which the single ingredient foods/whole foods category includes the subject of this report: foods that have not traditionally formed part of the diet in the broad community in Australia and New Zealand, such as foods from other parts of the world, traditional indigenous foods consumed by specific groups in the community, or new foods produced from traditional breeding techniques. The guidelines document states that "while there are many new foods on the market, it is likely that only those where there is some evidence of potential adverse effects would be considered novel”.

A safety assessment will be undertaken of those non-traditional foods for which, in the words of the Standard, there is "insufficient knowledge in the broad community to enable safe use in the form or context in which [they are] presented". An assessment of the level of knowledge about the safe use of a non-traditional food in the broad community of Australia and New Zealand is made in determining novelty.

\subsection{Conclusions on regulations}

The Novel Food legislation within the European Community and Australia/New Zealand include traditional foods with no documented history of food use in the definition of novel foods (the specific term in Australia/New Zealand is "non-traditional food"). Although there exist some common understanding in defining novel food, there is still room for interpretation and therefore a need to give a more precise definition in order to diminish this grey area.

In Canada and Australia/New Zealand the applications are handled by central authorities, whereas novel food applications within the EU are handled by the competent authority of the member state where the novel food is planned to be introduced on the market and the European Commission. The safety assessment of whole foods is far from routine and no 
harmonised international guidelines exist on how such assessments should be performed. However, some experiences have been gained in individual countries and in EU, which now can guide the process forward. 


\section{Historical experience}

\subsection{Food plants and food plant toxins}

Nowadays the general advice on good eating habits from a nutritional view point is to eat a variety of fruits and vegetables each day to ensure the intake of the necessary amount of nutritionally important proteins, amino acids, fats and fatty acids, complex carbohydrates, fibers, vitamins and minerals together as well as a variety of plant metabolites such as plant phenols, isothiocyanates, indoles and carotinoids with and without nutritional relevance. It is now recognized that an upper safe level exists for most of these plant constituents, and that many food plants as part of their self-protection against plant diseases due to microbes and pests form toxic plant constituents without any nutritional benefit, but maybe a health benefit to humans. Intake of plant foods like cassava (Manihot esculenta Crantz) and grasspea (Lathyrus sativus L.) may give rise to acute and chronic intoxications in human. In spite of that, the starch-filled roots of cassava have a major role in today's food supply in many tropical regions. The roots contain cyanogenic glycosides, and raw or inadequately processed roots may cause acute symptoms or chronic neurological disorders (see 4.8 for further details). Excessive consumption of the seeds of the legume grasspea causes lathyrism, a neurodegenerative and irreversible spastic paraparesis (Spencer et al. 1986, Getahun et al. 2003). The toxic substance is the neuroexcitatory amino acid $\beta$-N-oxalyl- $\alpha, \beta$ diaminopropionic acid (ODAP), but the direct effect of ODAP is still not figured out (Rao 2001). Since grasspea is highly drought- and floodresistant, the seeds may still constitute a major part of the diet during famine crisis. Outbreaks of lathyrism epidemics have occurred within the last ten years in Afghanistan, Nepal and Ethiopia. Recently there has been a renewed interest in cultivating grasspea in Italy and Poland (Getahun et al. 2005), and the first variety of grasspea (Ceora) with low level of ODAP is just released in Australia (Siddique and Hanbury 2005).

As the above-mentioned examples show, plant foods may nowadays give rise to safety concerns even in populations accustomed to their use. The examples also illustrate that proper use of plant foods both from a nutritional and safety point of view is the basic prerequisite for a stable and solid development and maintenance of the variety of human cultures and societies all over the world. 


\subsection{The Age of Exploration}

Since prehistoric times and over history new food items and new methods to prepare foods have gradually spread and enriched the European food supply. These introductions have generally been slowly implemented. Already our ancestors, the hunter-gatherers were forced to broaden their food resource base to encompass a wide array of food that was previously ignored in an attempt to overcome food shortages. Data supporting this "broad-spectrum revolution" hypothesis has mainly been of faunal origin such as type of bones found but recent data from caves in the Levant confirms that the 25.000 years old plant material recovered were both broad in origin (142 taxa) and with a high amount of small-grained grasses compared to cereals (wild wheat and barley) (Weiss et al. 2004). In the following 15.000 years, the cereals gradually replaced these smallgrained grasses. The proper shift from hunting and gathering to agriculture took place some 10.000 years ago in the Oriental region and broadened to the Europe, central Asia and India through the next millennia. Although the reasons for this "Neolithic revolution" are still not fully understood, the resulting domesticated plants are major food component in Europe such as wheat (developed to Triticum aestivum), barley (Hordeum vulgare) and pea (Pisum sativum) (Zohary and Hopf 2000).

In historic times the single remarkable and epoch-making event, which produced a mass introduction of novel foods in Europe, was the exploration of the "new" world. A large part of the plant foods considered nowadays as an integrated part of the European diet was first introduced in Europe some 400-500 years ago, following this "Age of Exploration". The food plants introduced during this period include potato (Solanum tuberosum), tomato (Lycopersicon esculentum), maize (Zea mays), groundnut (Arachis hypogaea) and pepper fruit (Capsicum annuum), which now are important staple foods and feeds. In the same period also cacao, vanilla, and allspice and a series of other spices, now highly appreciated as culinary delicacies, came along.

When the "Age of Exploration" began, the Solanaceae family was reputed in Europe for its toxic and medicinal members. It is therefore understandable that there was some resistance to accept food from this plant family such as potato, tomato and pepper fruits in Europe. These plants domesticated in central and south America in prehistoric times, were widely consumed in the Americas before Columbus. Today they are cultivated throughout the world and are some of the world's most important vegetables/tubers. They were all introduced in Europe shortly after 1500 AD but only pepper fruit was readily accepted as a food - as a substitute for pepper (Piper nigrum). Tomato can illustrate the slow acceptance of Solanum-like fruits in Europe. It was first in the late $18^{\text {th }}$ century that tomatoes were being grown and eaten in abundance in Italy and Spain. By 1800, when tomatoes had become the most common fruit in Spain, 
they were starting to be eaten in France, while in Northern Europe they were still regarded with suspicion.

\subsection{Before the EU regulation}

More recently, but before the EU regulation on novel food came into place in 1997, a number of exotic food plants has been introduced on the European food market. These exotic foods have presumably been placed on the market based on the assumption that their safety could be assured by their use as food in other parts of the world. Well-known examples are aubergine (Solanum melongena), squash (Cucurbita pepo), kiwi fruit (Actinidia delisiosa, A. chinensis), star fruit (Averrhoa carambola), cape gooseberry (Physalis peruviana) and durian fruit (Durio zibethinus).

The occurrence of toxic glycoalkaloids in different Solanaceae plants such as potatoes (S. tuberosum) has been investigated (Andersson 1999). In a 1984 review of the literature, 12 separate reports of potato glycoalkaloid poisoning, involving more than 2000 cases with about 30 deaths, have been presented. Moreover, the review argues that most of the mild and even the more serious "solanine" poisonings go unrecorded and are diagnosed as "gastroenteritis" (Morris and Lee, 1984). The content of total glycoalkaloids varies considerably between the different potato varieties. Based upon a risk assessment of the content of total glycoalkaloids in potatoes, the Nordic Group on Food Toxicology and Risk Assessment suggested back in 1990 a Maximum Tolerable Level of total glycoalkaloids in potatoes on $200 \mathrm{mg} / \mathrm{kg}$ unpeeled potatoes with suggestion to reduce the level to $100 \mathrm{mg} / \mathrm{kg}$ for new varieties (Slanina 1990). This limit is more or less adopted in development and marketing of new potato varieties, as well as in potato sale.

The potato case illustrates the kind of acute human health problems the unconsidered introduction of novel plant foods may lead to. Another example is the potential of the kiwi fruit to provoke human allergenicity (see chapter 4). No studies have been found investigating the influence of the novel plant foods on human long-term health effects such as cancer and cardiovascular disease in Europe.

\subsection{After the EU regulation}

Traditionally, foods have been considered safe because there has been no reported evidence of adverse effects over time, and/or because adequate knowledge has been acquired in the community with respect to food processing or preparation to address any identified hazard. The introduction of the Novel Food legislation in Europe, with its definition of novel foods has created a need for the establishment of the safety of exotic 
fruits and vegetables novel in Europe. Since the 15 May 1997 these products have to be assessed for their safety, which have to be found acceptable, before the products are placed on the market. It has been suggested that a number of plant foods introduced in Europe over time and now being an integrated part of the European diet would never have been accepted and thereby reached the European market, if they should have passed a pre-market approval like the one now being required according to the EU Novel Food regulation (EC No. 258/97). The main difficulties experienced so far in relation to novel plant foods in EU since 1997 relate to defining the borders of the area of regulation ("What is novel?") and to the lack of regulatory and scientific consensus on the type of safety data needed to perform the safety assessment and complete the premarket approval for foods deemed to be novel. This report addresses these questions.

\subsection{Conclusions on historical experience}

Both in prehistoric and historic times a number of novel plant foods have been accepted as part of the European food supply on the assumption that their safe intake is assured by their previous use in other parts of the world. Acute intoxications due to intakes of potatoes with high concentrations of glycoalkaloids are well known in Europe. No long-term adverse health effects due to plant foods have been reported, but at the same time no European epidemiological studies have investigated this issue in a systematic manner. 


\section{Examples - past and present.}

The following examples on introduction of plant foods, taken from the past as well as from recent years, have been compiled to illustrate various toxicological and regulatory aspects relevant to consider when new exotic fruit and vegetables are to be introduced on the market. The case studies illustrate problems or aspects in relation to, e.g. allergy, occurrence of natural toxins and history of safe use.

For each case the presentation is subdivided into a background section, a section on health and safety issues and a section regarding the assessment of latter issues. The cases can be subdivided in those "novel" plant foods, which already were introduced at the European food market some years ago like rapeseed, kiwi fruit, red kidney bean and carambole, those plant foods which were introduced only recently like lupin seed, nangai and noni juice, and those which could give rise to health and safety considerations in Europe if they were to be introduced like cassava.

\subsection{Rapeseed}

Background:

Domestication of Oilseed Rape is believed to have occurred in the early Middle Ages in Europe. At that time rapeseed oil was used primarily as oil for lamps and later as lubricants for steam engines. After the Second World War the interest in rapeseed breeding was intensified and directed to improve agronomic characters and oil quality. Animal studies have indicated as early as 1949 that consumption of large amounts of rapeseed oil with high levels of erucic acid could be detrimental (Boulter 1983). Therefore concerns about the nutritional safety of rapeseed oil and the potential impact on human health forced plant breeders to search varieties with low level of erucic acid in rapeseed oil. The first low erucic acid varieties in Brassica napus and in B. rapa were released in 1968 and 1971, respectively.

Rapeseed is also valuable for its meal, which is today used as a high protein feed supplement for livestock and poultry. Before the late 1970's rapeseed meal (by-product after oilseed processing) could only be used in smaller amounts as feed due to the presence of glucosinolates, which gave low palatability and goitrogenic effects. These adverse effects led to development of varieties of rapeseed combining low levels of both glucosinolates and erucic acid (double low varieties). The plant breeding toward lower level of erucic acid in the oilseed rape oil continues and 
canola varieties have replaced all other varieties (FSANZ 2003) (canola refer to $B$. napus or $B$. rapa lines containing less than $2 \%$ of the total fatty acids as erucic acid).

Health and safety issues:

From rat studies erucic acid is reported to be responsible for development of myocardial lipidosis and for heart lesions but a number of reasons has suggested that the rat model is not an appropriate model to determine whether erucic acid may pose a risk for human health, e.g. the fatty acid metabolisms in the rat is dissimilar to that of adult pig and primates, making rats highly susceptible to myocardial lipidosis and to necrosis and fibrosis in the hearts. Suckling pigs, however, are also developing myocardial lipidosis and scar formation, suggesting that the immature myocardium and/or liver may be less able to oxidise erucic acid. Therefore it seems reasonable to expect that (young) humans would also be susceptible to myocardial lipidosis and scar formation in the heart following exposure to high level of erucic acid (FSANZ 2003). Directive 76/621 of the European Community sets the maximum level of erucic acid in oils and fats intended for human consumption to $5 \%$ of the total level of fatty acids. Today most of the oils from commercial oilseed rape have lower than $1 \%$ erucic acid of the total fatty acids (FSANZ 2003).

Canola or double low oilseed rape oil (high oleic acid content) is not considered a novel food in EU, as it is unprocessed oil that were extracted from a conventionally bred rape variety and used in food production before 1997. However, the oil falls outside the Codex specification for unprocessed rapeseed oil with respect to the content of oleic and linolenic acids. It has a similar fatty acid profile, though, to processed rapeseed oils.

\subsection{Lupin seed}

Background:

The plant part used for human consumption is the dried seeds of either the White lupin (Lupinus albus L.), or of the Narrow leaved lupin also known as Blue lupin (Lupinus angustifolius L.), both annual upright plants belonging to the Fabaceae family. White lupins are grown in the Mediterranean area, North Africa and Australia. Narrow leaved lupin with low alkaloid content has been extensively cultivated in Australia from the 1980s and accepted for human consumption there. Both lupins contain a mixture of various quinolizidine alkaloids. For White and Narrow leaved lupin, cultivars with high and low alkaloid content exist.

Seeds of $L$. albus with high alkaloid content were used in the Mediterranean area as a snack food before 1997. The plant is included in the NETTOX-list as a food plant in Europe. The bitter seeds need soaking 
followed by cooking until bitterness disappears before they can be safely consumed. In 1998 France accepted the use of up to 10\% of lupin flour made from a variety of white lupin with low alkaloid content as a food ingredient provided that the alkaloid content did not exceed $200 \mathrm{mg} / \mathrm{kg}$. For low-alkaloid-containing $L$. angustifolius varieties the UK introduced maximum levels of the total alkaloid content $(200 \mathrm{mg} / \mathrm{kg})$ and the content of a group of mycotoxins named phomopsins ( $5 \mu \mathrm{g} / \mathrm{kg})$.

The development of cultivars with low alkaloid content has widened the possible use of lupins since the seeds can be used without further preparation. Flour from the seeds can be used in bread, pastry, biscuits and pasta. Lupin seeds can also be used to produce food ingredients such as protein isolates and lupin 'milk' (similar to soya 'milk') and can be used instead of soy beans as a food ingredient or in the production of a number of Asian fermented foods. Whole seeds can be used in soups and stew, sprouted for use in salads, and roasted as a snack food (ACNFP 1996).

Health and safety issues:

Symptoms of intoxication after ingestion of lupin seeds with high alkaloid contents arise 1-14 hours after the consumption and include dry mouth, muscular weakness, disturbed balance, sweating, palpitation, blurred vision, mydriasis (i.e. dilated pupils), urine retention, gastric and intestinal troubles and abundant ventricular extrasystoles. Three cases of lethality have been described in young children. Based on these human data, the deadly dose of alkaloids for a child was assumed to be 11-25 $\mathrm{mg} / \mathrm{kg}$ b.w. The dose that causes acute effects in adults has been estimated to 25-46 mg/kg b.w. (Schmidlin-Meszaros 1973). The acute oral $\mathrm{LD}_{50}$ of an alkaloid mixture from L. angustifolius was $2279 \mathrm{mg} / \mathrm{kg}$ body weight in rats dosed shortly after feeding and $2401 \mathrm{mg} / \mathrm{kg}$ body weight in fasted rats (Petterson et al. 1987). In a 90-day study in rats fed seeds from L. angustifolius, the no observed adverse effect level (NOAEL) was 28 $\mathrm{mg} / \mathrm{kg}$ body weight for male rats and $34 \mathrm{mg} / \mathrm{kg}$ body weight for female rats (Robbins et al. 1996). Cows that during pregnancy grazed on wild American lupin species containing the quinolizidine alkaloid anagyrine delivered calves with congenital defects described as 'crooked calves disease' (Panter and Keeler 1993). This very active quinolizidine alkaloid is, however, not present in seeds of L. albus and L. angustifolius (Wink et al. 1995). Dwarfism in calves and incomplete development of the distal limbs in lambs has been attributed to cows or ewes grazing on another lupin species Lupinus cosentinii (Allen 1998).

Safety assessment:

Lupin seeds derived from Lupinus albus and L. angustifolius are not considered novel foods within the EU legislation because of a history of consumption before 1997. Therefore, neither seeds nor lupine flours from 
low-alkaloid containing cultivars need an EU evaluation with regard to safety when used as food. However, in the United Kingdom the Advisory Committee on Novel Foods and Processes (ACNFP) evaluated the food safety of seeds from L. angustifolius based on two 90-day toxicological studies in rats, a multigeneration study in rats fed seeds from L. albus, data on the metabolic fate of lupin alkaloids and their pharmacological activity (ACNFP 1996). ACNFP concluded that the seeds of these species were safe to use provided that the total alkaloid level was less than 200 $\mathrm{mg} / \mathrm{kg}$ seeds or derived lupin products and that the level of phomopsins was below $5 \mu \mathrm{g} / \mathrm{kg}$. The Committee concluded that although lupin flour appeared to be capable of inducing allergic reactions in susceptible individuals, the proportion of the total population likely to show such reactions would be less than that reacting to existing food allergens such as soy proteins. The Committee also noted that cross-reactivity between lupins and soybean allergens (or other pulses) may exist. It was recommended that relevant health professionals and support groups should be informed of the introduction of lupin-based foods into the UK market (ACNFP 1996). No information to the consumers seems to have been required. Data on the difference in sensitivity between man and rat to the acute effects of quinolizidine alkaloids from $L$. albus and $L$. angustifolius as well as data showing that quinolizidine alkaloids from some lupin species may effect development in ruminants seem not to have been taken into consideration in the ACNFP safety evaluation.

Lupins, which were introduced on the Franch market in 1998, have caused seven of the 107 cases of severe anaphylaxis due to food consumption according to a report by French allergists (Morisset 2003). In comparison, well-known allergens like various tree nuts resulted in 16 cases, peanut in 14 cases, shellfish in 9 cases, and the latex-fruit group (avocado, kiwi, fig, banana) in 9 cases (Morisset et al. 2003). Recently in UK, a case of anaphylaxis in a woman was attributed to lupin flour used on onion rings in a restaurant meal (Radcliffe 2005). In Norway a person reacted with allergic symptoms after eating bread that contained lupin flour that was not included on the ingredient list. In both cases the patients were peanut-allergic. None of the papers dealing with lupin allergy specifies whether the allergic reactions are caused by L. albus or $L$. angustifolius.

Lupin flour was not included in the list of potentially allergic ingredients that should be specifically labelled by food manufacturers according to the directive on food labelling that came into force in Europe in November 2004 (Radcliffe 2005). Radcliffe (2005) suggests that since people with peanut allergy (around 1\% of the population in UK) seem to be at a particular risk they should be advised to avoid all products containing lupin until they can be specifically tested. 


\subsection{Kiwi fruit}

Background:

The kiwi fruit (Actinidia deliciosa (A.Chev.) CF Liang et AR Ferguson) belonging to the family Actinidiaceae, is a plant native to China. Seeds were taken to New Zealand in 1904, and almost all kiwi cultivars outside China are descendants from this collection including the "Hayward" cultivar (the traditional green flesh type of kiwifruits) (Ferguson 1999). Most of the recently commercialised hairless 'kiwifruits' with soft skin and yellow flesh, e.g. Hort16A, is actually from the species A. chinensis (yellow flesh type) (commercialised as Zespo Gold Kiwi) (Ferguson 1999).

Health and safety issues:

Acute allergic reactions to kiwi fruit were first described in 1981. Since then numerous reports have appeared describing allergenicity of kiwi. Kiwifruits has now become one of the major elicitors of plant food allergy. The symptoms of most patients with kiwifruit allergy are confined to the oral allergy syndrome. Some individuals show more severe reactions including angioedema, pharyngeal swelling, dyspnoea, urticaria, vomiting, and even cardiovascular collapse (Lucas et al. 2003).

Kiwifruit is involved in the pollen-fruit syndrome (birch and grass pollen cross reactivity) and the latex fruit syndrome. Half of the patients with latex allergy show an allergy towards avocado, banana, chestnut, kiwifruits and other fruits (Lucas et al. 2003).

Recently it is reported that the allergen composition of extract from the A. deliciosa 'Hayward' type of kiwifruit differ from extract of the A. chinensis 'Hort16A' type. Both cultivars express phytocystatin and a thaumatin-like protein as allergens. Two allergens with homologies to chitinases were only found in the 'Hort16A' type of kiwifruit, whereas actinidin was detected exclusively in the green kiwifruit (Bublin et al. 2004).

"Baby kiwi" or "berry kiwis" are developed from Actinidia arguta and can be grown in colder climates, even in Denmark. We know that the level of actinidin in A. arguta generally is higher than in A. deliciosa, therefore it is expected that most "berry kiwis" will have a higher potential for eliciting allergenic reactions.

Safety assessment:

The term "kiwi fruit" covers fruits collected and marketed from several species (at least 4), without considering the potential differences between these species in relation to health and safety issues (allergy). It is in fact possible in the breeding programme to incorporate such elements.

Another question is what are the limits for the name kiwi. The kiwi name already covers fruits from at least 4 Actinidium species and in addi- 
tion rootstocks for the scion are often from other species, e.g. A. polygama, influencing the fruit characterization.

\subsection{Red kidney bean}

Background:

Kidney beans are kidney shaped mature dried seeds of the common bean or garden bean (Phaseolus vulgaris L.), a member of the Fabaceae family. Two major gene pools of Phaseolus vulgaris have been identified and the kidney bean is a representative of the Andean gene pool (Southern Peru, Chile, Bolivia and Argentina) and has been cultivated for at least 7000 years (McClean et al. 2004). The common bean was introduced into Europe through the Columbian exchange and the first detailed description of common bean in Europe was published in 1543 in the Herbal of Fuchs (Gepts 2002).

Health and safety issues:

The common bean (Phaseolus vulgaris) contains a family of plant defence proteins that includes phytohemagglutinin (PHA). PHA is a lectin that binds to the glycans of the intestinal mucosa of mammals and acts as a mitogen. In red kidney beans the level of PHA is particular high compared to most other types of beans, and it is necessary to inactivate the PHA in red kidney beans before human consuming.

Safety assessment:

All persons, regardless of age or gender, appear to be equally susceptible to toxic lectins; the severity being related to the type of lectin and the dose ingested. Lectin intoxications are usually caused by the ingestion of raw or soaked kidney beans that have not been boiled enough. These beans may have been consumed as such or in salads or casseroles. As few as a couple of raw red kidney beans may be able to cause intoxication. Onset of symptoms occurs from between 1 to 3 hours after consumption, and is usually characterised by an extreme nausea followed by vomiting. Diarrhoea develops somewhat later (from one to a few hours), and some persons report abdominal pain. Hospitalisation is sometimes needed, but recovery is usually rapid (3 - $4 \mathrm{~h}$ after onset of symptoms) and spontaneous. Several outbreaks have been associated with "slow cookers" or crockpots, or with casseroles which had not reached a high enough internal temperature to destroy the lectin. It has been shown that heating to $80^{\circ} \mathrm{C}$ may increase the toxicity five-fold, so that these beans are more toxic than if eaten raw. In studies of casseroles cooked in slow cookers, internal temperatures often did not exceed $75^{\circ} \mathrm{C}$ (CFSAN, 1992).

To avoid intoxication different cooking procedures have been recommended. The Public Health Laboratory Services, Colindale, U.K. recom- 
mend the following procedure for kidney beans and other beans: Soak the beans in water for at least 5 hours, pour away the water and boil briskly in fresh water for at least 10 minutes. The Danish Food Agency, however, recommended in 1989 a longer soaking period (8 hours) and at least 45 minutes boiling (Levnedsmiddelstyrelsen, 1990).

\subsection{Carambole (star fruit)}

Background:

Averrhoa carambola L. (Carambole, Starfruit) was introduced in the EU a few decades ago. Carambole is an up to $10 \mathrm{~m}$ high tree belonging to the Oxalidaceae family, producing 8-12 cm long light to golden yellow fruits with five sharp ridges that form a characteristic star-shape when the fruit is cut in slices across the ridges. The form of these slices has given the fruit its trivial name 'star fruit'. Although the plant originates from Ceylon and the Moluccas, it is nowadays grown in many other tropical and subtropical regions of the world.

There are trees of two types. The first one is producing smaller and sourer fruits, which, however, are richly flavoured and contain higher levels of oxalic acid than the other type of tree. The second type is producing larger and sweeter fruits that are mildly flavoured and contain less oxalic acid (Morton, 1987; Yang et al., 1995; Chen et al., 2001). Fruits of the sour type are rarely consumed fresh but used in the production of carambole juices.

Health and safety issues:

Since 1993 several investigators have reported intractable hiccups and/or severe neurological effects after ingestion of moderate quantities (half a fruit to ten fruits) of carambole fruit, or corresponding amounts of juice, in patients on a regular programme of haemodialysis (Martin et al., 1993; Moyses Neto et al., 1998, 2003; Chang et al., 2000, 2002; Tse et al., 2003).

The time from ingestion of carambole to onset of symptoms of intoxication has been reported to range from 0.5 to $14 \mathrm{~h}$. The most common symptoms among the 32 patients of Moyses were persistent and intractable hiccups (94\%), vomiting (69\%), disturbed consciousness (66\%), decreased muscle power, limb numbness, paresis, insomnia and paresthesias (41\%), seizures (22\%), and haemodynamic instability (9\%) (Moyses Neto et al., 2003). A substantial percentage of affected patients died.

As haemodialysis was a successful treatment of the intoxication, it seems likely that dialysis removes the toxic substance from the blood (Martin et al., 1993; Chang et al., 2002; Moyses Neto et al., 2003). It has been suggested that carambole contains a powerful neurotoxin that can accumulate in the blood and cross the blood-brain barrier in chronic renal 
patients, and eventually cause irreversible damage (Moyses Neto et al., 1998).

Safety assessment:

With two exceptions, all cases of carambole intoxication have occurred in persons with severe kidney failure, requiring haemodialysis. The two exceptions were seemingly healthy individuals that developed acute oxalate nephropathy (renal failure shown by blood chemistry and renal biopsies) needing haemodialysis after ingestion of large quantities of juice (1.6 and $3.1 \mathrm{l}$, respectively) from sour carambole on an empty stomach (Chen et al., 2001). The authors suspected oxalic acid to be the toxic principle in the carambole as the cases had ingested approximately 13.1 and $9.2 \mathrm{~g}$ oxalate, respectively. Oxalic acid and its soluble salts are poisonous to humans and animals, whereas insoluble salts of calcium and magnesium oxalate are not (Sanz and Reig, 1992). Oxalates ingested by humans together with other foods may be precipitated by calcium as an insoluble complex, which then is excreted in faeces. The lethal dose of soluble oxalate varies from 2 to $30 \mathrm{~g}$ in humans (Beier, 1990). Support for their hypothesis were obtained in feeding studies of rats with normal oxalate containing and prepared oxalate-free carambole juice (Fang et al., 2001; Chen et al., 2002).

To avoid acute oxalate nephropathy, rarely observed in healthy individuals, it has been suggested that pure sour carambole juice should not be consumed in large quantities, especially on an empty stomach or in a dehydrated state (Chen et al., 2001).

The hypothesis that oxalic acid is responsible for the neurotoxic effects of carambola in hemodialysis patients has been questioned, as it does not fit with oxalate exposure from other foods. Although rhubarbs, and plants such as curly dock (Halogeton glomeratus), containing similar amounts of oxalate to carambole, have caused acute oxalate nephropathy in humans as well as in animals (Panciera et al., 1990; Sanz and Reig, 1992), no neurological effects similar to those induced by carambole in patients on haemodialysis have been reported. Furthermore, consumption of vegetables, such as spinach or beets, that also contain high levels of oxalate have never been reported to be associated with acute oxalate nephropathy. It is of course possible that cooking may reduce oxalate absorption. In conclusion, at present the identity of the (neuro) toxin in carambole is unclear.

\subsection{Nangai or ngali nut}

Background:

The Nangai, Ngali, Canarium nut (Canarium indicum L.) is a member of the Burseraceae family. The plant part used for human consumption is the 
kernel (almond) of the nut. The fruit has an outer fleshy mesocarp and a hard endocarp covering the kernel. The nuts are normally sold as "nut-inshell" (with endocarp) or as "kernel-in-testa"(without endocarp) (Thomson and Evans, 2004).

An application to put this product on the European market was submitted to the Competent Authority in France at the end of 1998. According to information from the novel food applicant, an average nut-in-shell weighs about $14 \mathrm{~g}$ (8-20 g). The nut-in-shell contains from one to three kernels (weight about $3 \mathrm{~g}$ each), which are the edible part from the tree. The nutrient profile of nangai nuts closely resembles that of nuts in general. Thus, they are characterised by a high fat content, around $45 \%$ with $48.5 \%$ of the fatty acids being saturated, $38 \%$ being monounsaturated and 14\% being polyunsaturated (English et al., 1996, Thomson and Evans, 2004). According to information from the applicant, the estimated consumption of nangai nuts in Western Melanesia is about 60 tonnes of almonds or about $70 \mathrm{~g} /$ person/day.

The nangai nuts were classified as novel foods within EU. The French authority that received the novel food application and performed the primary safety assessment gave a positive opinion on the application in 1999 but suggested a conditioned approval. It was suggested that the approval should be conditioned regarding microbiological quality, regular monitoring of aflatoxin levels and labelling requirements similar to those for nuts in general because of the potential risk for allergenicity. However, four member states raised objection to the primary assessment. In their view the applicant had failed to show that consumption of nangai nuts did not lead to toxicity. A safety concern was raised because of the lack of toxicity data. The microbiological investigation of the indigenous flora of the nuts was found to be incomplete and therefore the product was found not to comply with the current EU hygiene standards. The Commission decided to consult the Scientific Committee on Food for evaluation of the potential health concerns related to the food use of the product. They gave their opinion in 2000 (SCF 2000).

Health and safety issues:

Concern was raised against missing toxicity data, the potential allergenicity of the nuts and their hygienic standard.

Safety assessment:

The Scientific Committee for Foods concluded that the information submitted to demonstrate the safety of the nangai nuts was incomplete with regard to the analytical procedures employed for determining their nutritional composition and the extent of natural variation of the data submitted (SCF 2000). Furthermore, the possible allergenicity of nangai nuts had not been investigated and adequate toxicological data were not available. Therefore, according to the assessment procedures laid down in EU 
Regulation 258/97, Article 6.1 and in the Commission Recommendation of 29 July 1997 (97/618/EC) for the evaluation of the safety of novel foods, no conclusions could be drawn on the safety of consuming the nangai nuts.

Two reports concerning the potential allergenicity of nangai nuts in humans not previously exposed to this nut have been published after the SCF expressed its opinion. One of these reports describes a possible cross-reactivity between nangai nuts and various tree nuts - pistachio, hazel nut and cashew nut (Frémont et al. 2001). The other report shows a possible IgE-cross-reactivity in patients suffering from grass, birch and mugwort pollen allergy (Sten et al., 2002).

\subsection{Noni Juice}

Background:

Noni (Morinda citrifolia) is a small tree or shrub belonging to the family Rubiaceae and native to the region from south-eastern Asia to Australia. The tree produces a yellowish white, fleshy, $5-10 \mathrm{~cm}$ long fruit (the syncarp) (ca. 3-4 cm in diameter) that become soft and fetid when ripe. In Hawaii Noni was originally cultivated for its medicinal and dye properties, and has now become naturalised in relatively dry sites, at altitudes 0 $450 \mathrm{~m}$. All parts of the plant are used, including roots and bark (dyes, medicine), trunks (firewood, tools), and leaves and fruits (food, medicines). It is an important sources of traditional medicine in the South-East Asia (Tap and Bich 2003) The medicinal applications, both traditional and modern, span a vast array of conditions and illnesses, although the efficacy of most of these applications has yet to be scientifically supported. Noni has attained significant economic importance worldwide in recent years through a variety of health and cosmetic products. These include fruit juices as well as powders made from the fruits or leaves.

Considering a request for placing pasteurised fruit drinks of the noni fruit (Morinda citrifolia) on the European market in 2000, the Belgian authority came to the conclusion that an additional assessment was required. This additional assessment was requested from the EU Scientific Committee on Food (SCF), which considered the product acceptable at intake levels up to $30 \mathrm{ml}$ per day (SCF, 2002).

The EU authorisation of Noni juice as a novel food ingredient dates to 5 June 2003 and is limited to a particular product, juice of the noni fruit (Morinda citrifolia) produced by Morinda Inc, for use in pasteurised fruit drinks. No other producets of noni products, say jam, spray dried juice, or whole dried fruit, can use the authorisation unless evidence can be presented of substantial equivalence.

The authorisation from the European Commission further stated that the SCF noted that the data supplied and other information available pro- 
vided no evidence for special health benefits of "Noni juice" which go beyond those of other fruit juices, and that Morinda Inc., therefore, might not sell the products as promoting health.

Health and safety issues:

SCF considered in 2002 the product acceptable at the suggested levels of intake, at most $30 \mathrm{ml}$ per day (SCF 2002). The overall usage has increased considerably since then, and in 2005 three reports on acute hepatitis caused by Noni preparations have been published (Millonig et al., 2005; Stadlbauer et al., 2005).

Safety assessment:

SCF based its conclusion regarding the safety on the information about the chemical composition of the fruit juice, as well as the toxicity and allergenicity data supplied by the applicant.

\subsection{Cassava (Manihot esculenta Crantz)}

Background:

Cassava is grown for its enlarged starch-filled roots, which contain about $30 \%$ starch and very little protein. Cassava grows well in a tropical climate and is eaten primarily in Africa, Pacific Island Countries, South America and regions of Asia including Indonesia. Cassava is consumed in a number of forms: flour used for cooking, root slices, root chips, baked grated root, steamed grated root, pan fried grated root, steamed whole root, and tapioca pearls made as a pudding. Cassava contains a toxic, cyanogenic glycoside, linamarin, which break down upon disruption of the plant cells to form hydrogen cyanide (HCN).

There are a number of varieties of cassava, each of which has a different cyanide level. Traditional uses of cassava as food are dependent on adequate processing prior to human consumption. Values from 15-400 $\mathrm{mg} / \mathrm{kg}$ fresh weight of HCN in cassava roots have been reported in the literature. Sweet varieties of cassava (low cyanide content) can be processed adequately by peeling and cooking (e.g. roasting, baking or boiling), whereas bitter varieties of cassava (high cyanide content) require more extensive processing, involving techniques such as heap fermentation, which take several days. Bitter varieties are not normally commercially traded.

Health and safety issues:

If cassava is eaten raw or after inadequate processing, evidence of both acute and chronic toxicity, may be observed. The symptoms of acute cyanide intoxication include rapid respiration, drop in blood pressure, rapid pulse, dizziness, headache, stomach pains, diarrhoea, vomiting, 
mental confusion, twitching and convulsions. In extreme cases, death due to cyanide poisoning may occur. The chronic effects of cyanide intoxication are linked to regular long-term consumption in individuals with poor nutritional status and include: konzo, an upper motor neuron disease; tropical ataxic neuropathy, a term used to describe several neurological syndromes; and goitre and cretinism, which are caused by iodine deficiency and can be considerably aggravated by a continuous dietary cyanide exposure.

Safety assessment:

Ingested cyanide follows the known cyanide metabolic pathway and toxicokinetics in humans whereby cyanide is detoxified by the enzyme rhodanese, forming thiocyanate, which is excreted in the urine. This detoxification requires sulphur donors, which are provided from dietary sulphur amino acids. There are several factors influencing the hydrolysis of cyanogenic glycosides, and therefore, the overall toxicity. These include nutritional status, particularly with respect to protein, riboflavin, vitamin B12, sodium and methionine.

The likelihood of cyanide intoxication from consumption of cassava is dependent on body weight and it is possible that a child or person of smaller body weight would not be able to detoxify the cyanide resultant from a meal of inadequately prepared cassava. The acute lethal dose of HCN from human is reported to be $0.5-3.5 \mathrm{mg} / \mathrm{kg}$ b.w. Approximately 50-60 mg of free cyanide from cassava constitutes a lethal dose for an adult man.

In populations where cassava does not have a tradition of use and where the community may not possess adequate knowledge regarding the risks of insufficient preparation, widespread use in the community would increase the public health risks.

\subsection{Conclusions on experiences from past and present cases}

The case stories confirm the old saying of Paracelsus that everything is poisonous, it only depends upon dosage. Most food items do carry inherent safety problems of chemical nature, which eventually in accidental situations or due to wrong handling procedures may lead to acute or chronic disease situations.

Consumers at the regional or local level or belonging to specific ethnical groups have learned by experience how to cope with negative characteristics of their native foods either by avoiding them (allergenicity from kiwi or nuts), limiting intake of them (selecting for low alkaloid lupin seeds) or using special preparation procedures before eating them (soaking and cooking of red kidney beans), or by accepting the risk of 
adverse health effects based upon a cultural risk/benefit tradition, where the benefit of availability of such foods counts heavily on the beneficial side of the equation (cassava).

As illustrated in the cassava case (i.e., "in populations where cassava does not have a tradition of use and where the community may not possess adequate knowledge regarding the risks of insufficient preparation, widespread use in the community would increase the public health risks"), novel plant foods may need special attention when introduced in countries and regions, where there is no tradition for their use. 



\section{Potential for new, novel plant foods to be introduced on the EU market.}

Present day global food supply has become increasingly dependent on only a handful of crops. More than $50 \%$ of the worldwide requirement for plant-derived proteins and calories are met by only three cereals: maize, wheat and rice. Thirty plant species used today meet $95 \%$ of the world's total food energy supply coming from intake of plant foods (FAO, 1996). The production figures from these 30 food plants are given in table 1 . Around 150 plant crops have a significant commercialisation on a global scale.

Table 1.The world production figures of thirty major food crops taken from Faostat 2004 (megatons) (Janick, 1999).

\begin{tabular}{|l|l|l|l|l|l|}
\hline Food group & Species & $\begin{array}{l}\text { Production } \\
\text { (megaton) }\end{array}$ & Food group & Species & $\begin{array}{l}\text { Production } \\
\text { (megaton) }\end{array}$ \\
\hline Cereals & Maize & 638 & Vegetables & Tomato & 113 \\
\hline & Rice & 589 & & Watermelon & 91 \\
\hline & Wheat & 556 & & Cabbage & 66 \\
\hline & Barley & 142 & & Onion & 57 \\
\hline & Sorghum & 60 & & Bean & 25 \\
\hline & Millet & 30 & Fruits & $\begin{array}{l}\text { Bana- } \\
\text { na/Plantain }\end{array}$ & 102 \\
\hline & Oat & 26 & & Orange & 60 \\
\hline & Rye & 15 & & Grapes & 60 \\
\hline & Soybean & 189 & & Apple & 58 \\
\hline $\begin{array}{l}\text { Oil seeds and } \\
\text { oil-legumes }\end{array}$ & Cottonseed & 56 & & Mango & 26 \\
\hline & Coconut & 53 & Tubers & Potato & 311 \\
\hline & Rapeseed & 36 & & Cassava & 189 \\
\hline & Groundnut & 36 & & Sweet potato & 122 \\
\hline & Sunflower & 28 & & Yams & 40 \\
\hline & Sugarcane & 1333 & & & \\
\hline Sugar crops & Sugar beet & 234 & & & \\
\hline & & & & & \\
\hline
\end{tabular}

A number of other food plants are contributing to the last percentages of the daily plant food supply. The EU AIR project NETTOX, 1995-1997, compiled and evaluated data on natural food plant toxicants in the European food supply in order to assess the human health risk of consuming plants with such toxicants, and to identify strategies to minimize such risks (NETTOX 1998). For this purpose the NETTOX project produced a list containing all the food plants species, including spices (and mush- 
rooms), consumed in Europe in 1997. This list containing about 300 food plants was in 1997 agreed to be a comprehensive list of food plants from a European perspective by food experts from 15 European countries (the NETTOX list with English and Latin plant names is given in Annex 3). It seems unlikely that foods derived today from the edible parts of the NETTOX plants (as defined in the monographs of the list) would be considered as novel foods in a EU context. The NETTOX list is presently being updated in a new EU project EUROFIR in the light of EU being enlarged by the accession of 10 new Member States.

Ethnobotanical surveys performed by the International Plant Genetic Resources Institute (IPGRI) indicate that across the world 7000 plant species are cultivated or harvested from the nature to complement the food supply (Wilson, 1992; IPGRI, 2004). This corresponds to approximately $10 \%$ of the estimated number of edible species present in nature (Myers, 1983). Below are given some examples of more specified lists of food plants developed in different contexts.

IPGRI hosts a list (called NUS) on their web-site with examples on neglected and under-utilised crop species in different parts of the world. This list comprises about 100 plants, some of which would likely be considered novel fruits or vegetables in the European Union (Annex 1).

Similarly, Hegarty et al. (2001) listed around 100 Australian bushfood plant species, which had been ingested by the aboriginals. For the great majority of the bushfoods examined, there are no reports on adverse effects following normal usage and intake despite enquiries in the communities where they are consumed. Although some of these plant foods may not be considered novel foods in an Australian/New Zealand context, they most likely would in a European context.

A compilation from 1999 of useful Peruvian plants recognized 782 edible plants species for that country alone (Brack Egg, 1999), and a global inventory of food crops listed several thousand edible species that are either cultivated or collected from the wild (Kunkel, 1984, Hermann, personal communication). These few examples illustrate that there are many plants that have a history of (safe) use as food in the regions where they grow but they would potentially be classified as novel foods if they were to be introduced onto the market in the European Community today.

In view of the on-going general climatic and demographic changes, the need for alternative crops to meet these conditions may only be encountered through the introduction and utilisation of novel food crops and varieties of novel food crops selected from this extant crop biodiversity. Therefore a number of non-traditional plant food crops may become introduced, not only in Europe, but also in the world market in the years to come, thereby underlining the need for introduction of generally agreed means and methods to assess the safety and the nutritional properties of the novel foods derived from such plants. 


\subsection{Conclusions on the potential for novel plant foods to be introduced in Europe}

Around 30 food plants serve $95 \%$ of daily intake of plant food calories. In Europe the last percentages of the daily plant food are delivered by roughly 300 other plant species. Both the 30 and the 300 plants have the potential to deliver novel food items from plant parts which have not hitherto been used in the human food supply but the major potential source for novel plant foods is the nearly 7000 other plant species used in the human food supply in other parts of the world.

This report focuses on the situation when novel food items from these 7000 plants are to enter the European market. 



\section{Assessment of novelty and safety of plant foods.}

Foods that are well known and traditional in one country or region may be unknown and thereby novel in another country or region. As exemplified in chapter 4 the knowledge and the traditions developed in each country or region on how to handle the individual plant food item are of great importance for the safe use of it. Some of these traditions actually assist in preventing development of acute or chronic diseases which may be linked to too high intakes of that food item or to the intake of unprepared or wrongly prepared plant food.

Today there is great interest in the introduction of novel foods many of them with health-promoting claims and often with the claims telling that they have a long history-of-use somewhere, far away. Some countries have developed legislation to prevent potential health or safety problems raised by the introduction of such products in their market. The legislative approach taken usually builds upon a distinction between the traditional foods and the so-called novel foods in that country or region.

The European, the Australian/New Zealand and the Canadian Novel Food Regulations are good examples. All demand a pre-market notification or assessment and acceptance/approval of the novel foods, before the products are placed on the market. The EU, the Canadian and the Australia/New Zealand regulations all require that the determination that something is novel is the first step and considered distinct from the safety assessment, which is second.

Two main issues immediately come up with such a legislation: the first one is the challenge on how to determine if a food item is traditional or novel, and to decide on the degree of un-familiarity which makes the food item novel. The second challenge is to establish what kind and extent of safety data is needed to make a safety assessment of an acceptable sensitivity and predictability of such a novel plant food. Both challenges carry a strong scientific component, but in the end both are management decisions.

The present chapter focuses firstly on general criteria defining novelty of exotic fruits and vegetables, and secondly on general criteria for assessing their safety in use based on the present scientific experience in the field and building on the present managerial approaches taken. The overall approach suggested below consists of a proposal for a management procedure to separate novel plant foods from traditional plant foods and a proposal for a management based scientific assessment policy to establish the safety of those plant foods defined as novel foods. 
This 2-step procedure complies with the approaches taken in the risk analysis process as described by FAO/WHO (1995, 1997), SSC (2000, 2003 a, b) and NNT (Fabech et al., 2002). The separation of novel plant foods from traditional plant foods becomes part of the establishment of the risk profile, and the scientific assessment policy becomes identical to the management driven establishment of the risk assessment policy as the basis for the conduct of the risk assessment.

\subsection{Determination of novelty of the plant food as part of the establishment of a risk profile}

Risk profiling is the process of describing a food safety problem in its societal context in order to identify those elements of the risk and benefit relevant to various risk management decisions.

The risk profile is based on available knowledge and is not a complete risk-benefit assessment but a first step. A typical risk-benefit profile includes the following:

- A brief description of the situation

- Products or commodities involved

- Information on present intake/exposures

- Values expected to be placed at risk, e.g. human health

- Economic concerns

- Potential consequences

- Consumer perceptions of risks and benefits

- The societal distribution of risks and benefits

The decision, whether a plant food is novel (or not), will emerge from the discussion points listed above.

The Working Group has looked at the information presented in the previous chapters regarding the variability of regulations introduced around the world, the historical experience, the potential for novel plant foods to be introduced on the European market in the future, and the examples on past and present introductions of novel plant foods in Europe.

The Working Group recognised early that it is impossible to define the individual food item as a novel food for a country or a region from a purely scientific point of view and therefore encompassed the necessity of including the management perspective in the decision on the novelty of foods derived from plants. The history of (safe) consumption is already recognised as an important part of the background information necessary for this decision in EU, Canada and Australia New Zealand.

The Working Group adopted the Australian/New Zealand approach to divide foods in traditional foods and non-traditional foods and let a subset of the latter be considered novel foods if there is insufficient knowledge 
in the broad community to enable safe use in the form or context in which it is presented, taking into account the composition or structure of the product, the levels of undesirable substances in the product, the known potential for adverse effects in humans, the traditional preparation and cooking methods, or the patterns and levels of consumption of the product. The scientifically based information required to establish the riskbenefit profile is a risk management tool influenced by societal values and traditions and leads to the conclusion on the novelty of the food in question.

The Working Group looked at the possibilities for developing a more generic approach to the process of defining novelty based upon the information in chapter 5 on plant sources used for the global food supply. This approach was especially triggered by the information from FAO about the worldwide production of different crop plants for food purposes telling that a very limited number of food plants meet $95 \%$ of the world's food energy needs from plants. Along the same line of thinking the EUAIR research project NETTOX identified 307 food plants in the human diet in the 15 Member States of the European Community in 1998. The idea with the NETTOX list was to include as a start at least all major plants (and mushrooms) used for human consumption in Europe. Since IPGRI at the same time has identified more than 7000 plant species as potential food sources, this demonstrate the future potential for many human populations to be presented for non-traditional or novel plant foods coming from plants they never have seen before in their area. This information also opens up the possibility to develop a more systematic approach to determine novelty based on the botanical identity of the food source.

On this background the Working Group developed the decision tree presented in figure 1 with the aim to obtain a rational, logic and simple device for the identification of novel plant foods on a global, regional or local scale. The decision tree is developed to be used for foods from plants, both plant species, varieties and sub-varieties of plant species. Similarly the decision tree approach undoubtedly can be adapted to foods from mushrooms, microorganisms and animals (but this is outside the scope of the present report).

The following definitions have been applied for this decision tree for the assessment of the novelty of food from conventional plants:

- Plant foods: Products used as food with a plurality of chemical constituents in a complex, holistic interplay ranging from intact fruits and vegetables, over complex botanical products like flour and botanical extracts to oils, fibres and proteins. Distinct from pure chemicals with only one chemical entity as the building block.

- Traditional foods: Foods with a history of significant human consumption by the broad community for several generations as part 
of the ordinary diet and thereby generally recognised as safe at the global, regional or local level or by an ethnic group.

- Non-traditional foods: Foods with no history of significant human consumption by the broad community for several generations as part of the ordinary diet.

- Novel foods: Non-traditional foods for which there is insufficient knowledge in the broad community to ensure safe use, or which have characteristics that raise safety concerns due to composition, levels of undesirable substances, potential for adverse effects, traditional preparation and cooking, and patterns and levels of consumption.

- Global list of traditional food plants: A list of plants, identifiable by name and delivering specified plant material used for traditional foods at the global level.

- Regional lists of traditional food plants: A set of lists with plants delivering plant material used for traditional foods at the regional level covered by the individual list. "The Region” may be defined on the basis of the five regional dietary patterns described by WHO/FAO in GEMS (WHO, 2003): Middle Eastern, Far Eastern, African, Latin American and European (incl. Australia, Canada and the USA), or as economical or regulatory entities like EU or Australia/New Zealand. When finalised the lists should cover all geographical regions of the world, thereby supplementing each other.

- Local lists of traditional food plants: Lists with plants delivering plant material used for traditional foods at the local level. A "Local lists" could cover EU, or individual nations like Denmark and China, or an area with a human population of mixed ethnic origin within a region or nation.

- Ethnobotanical lists of traditional food plants: Individual lists with plants delivering plant material used for traditional foods by individual ethnical groups. "Ethnobotanical lists" are lists developed to cover well-established plant food eating habits of a defined ethnic entity, e.g. aboriginals in Australia.

At the top of the Decision Tree in Figure 1 plant foods are divided into the traditional worldwide plant foods and plant foods with no worldwide tradition. Traditional plant foods at this level of the decision tree need no further assessment of their safety. They are by definition meant to be accepted regionally and locally all over the world.

Non-traditional plant foods from the global level of the Decision Tree should then at the regional and local level be subdivided further into plant foods regionally and/or locally accepted as food and those not regionally and/or locally recognised as food. If a non-traditional plant food from the global level is accepted as food at the regional level, it implies that it is accepted also locally, while a locally accepted food still may be considered novel at the higher regional level. 
For the purpose of understanding and evaluating the decision tree approach suggested in figure 1, two lists of plants have been prepared as preliminary examples. The first one appearing in Annex 2 is a modified FAO-list of plants (FAOSTAT 2004) with non-food items excluded. These plants are worldwide recognised as food sources and can thus make the first prototype for a global list. It should be mentioned, however, that for some products on the FAO list it may not be clear whether they should be defined as food or not, like Areca Nuts (betel), that might be considered as food or medicine in different part of the world. For risk management purposes, therefore, a final global list of foods will need an international acceptance by risk managers.

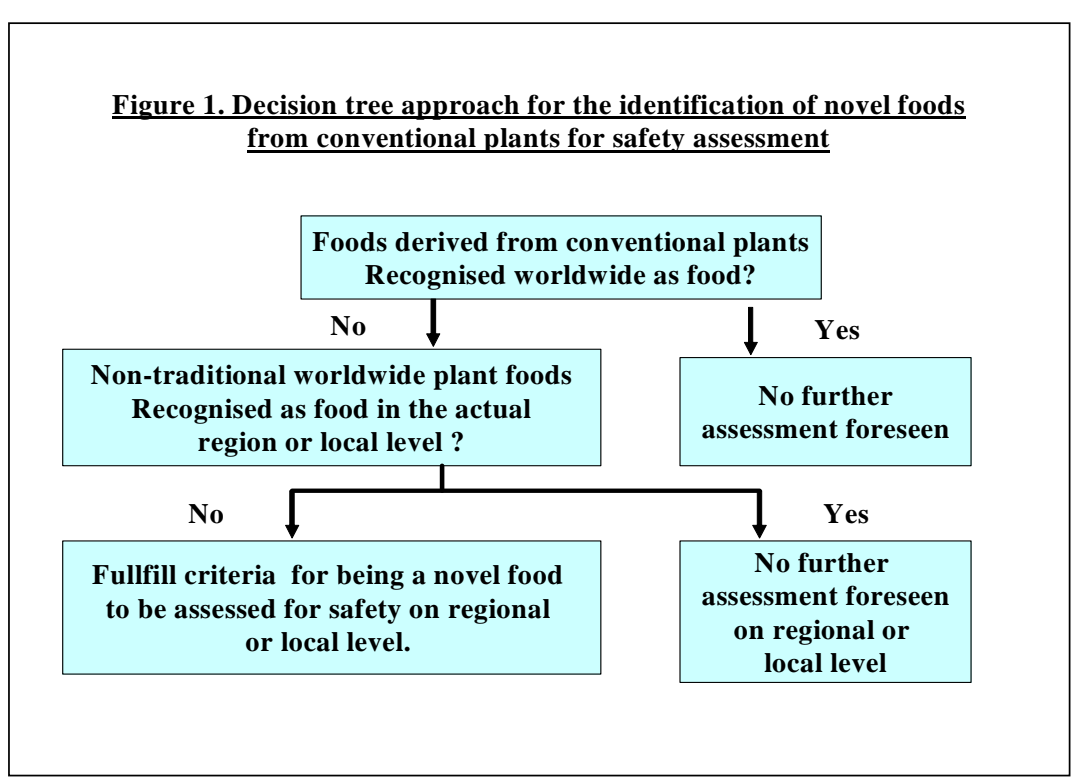

The second list in Annex 3 is the prototype for a regional or local list consisting of plants with no worldwide recognition as sources for major food items. Basically such a regional or local list as the one in Annex 3 can be generated from a list of all food plants in the area by subtracting the plants from the modified FAO list in Annex 2. The list in Annex 3 is made in this way and represents the first prototype of a regional/local list covering food plants used in the EU in 1998 (NETTOX 1998) excluding the ones on the list in Annex 2. Altogether the food plants on the global list and the regional list make up the total number of food plant traditionally used in that region.

The use of lists such as FAO list (Annex 2) as a global list and the modified NETTOX list (Annex 3) as a regional or local list in the Decision Tree Approach in figure 1 immediately identifies differences in basic approaches and lack of information. The FAO list used as the basis for the global list in annex 2 is based on production figures and use common names for the plant items, and although most items like maize, rye, oats, brazil nuts, tomatoes, eggplants and carrots include only one species, many items on the list include more than one plant species. Examples of items, 
which include a group of plants, are wheat (Triticum aestivum, T. durum and $T$. spelta), millets (7 or more different botanical small-grained cereal species) and beans (different Phaseolus and Vigna species). Therefore some of the plant species might only contribute to a very minor extent and have limited history of use. The NETTOX list in annex 3 on the other hand is based upon single plant species with Latin names but is still not comprehensive in covering all the known plant foods on the market in EU.

However the lists give a good starting position for identification and evaluation of exotic fruits and vegetables as sources for novel foods at the global, regional and local level of regulation. If the food plant lists are to be more useful or fitted for the evaluation of history of use, such lists should be based on single plant species with Latin names and include information on the plant part(s) normally used for consumption, recommendations for preparation and cooking procedures would also be of value. For some plants even specification of the specific plant varieties may be of importance since for some species the varieties may differ a lot in relation to safe use (glycoalkaloid content in potatoes, lectins in beans).

Foods derived from the plants included in the lists of Annex 2 and 3 will as a rule-of-thumb not be considered novel food in the EU region, unless parts not usually used as sources for food (as the stalk of wheat) are used in the production of food for humans. New food items derived from non-hitherto-consumed parts of traditional food plants will need further assessment at the scientific level based on scientific tools and scientific information described in chapter 7. The lists in annex 2 and 3 could thus be the managerial starting point for the classification of food from conventional plants not on these lists as novel, meaning moving such food items to a formal safety assessment.

It has not been possible to make a list of conventional plants which may deliver novel food from an EU point of view within the framework of this project, but as an example it can be mentioned IPGRI has made an inventory of native American fruits covering 1128 species, 285 genera and 66 families (IPGRI, 2005).

\subsection{Establishment of a risk assessment policy for conduct of the scientific risk assessment}

The individual, scientific safety assessment needs to be preceded by a general decision on a risk assessment policy in order to make the outcome of the safety assessment accepted as the basis for the management decision regarding the unconditional acceptance of the novel food item on the market, its limited acceptance on the market or its rejection from the market.

The establishment of a risk assessment policy for novel plant foods starts with science where scientists in the field identify the safety data 
needed to obtain different degrees of scientific sensitivity and specificity of the risk assessments and thereby predictability/reliability of their risk assessments. Afterwards it is a management decision on this basis to make a policy decision regarding the necessary availability of data e.g. in the form of a premarket data set.

This section discusses the nature and the extent of scientific data that will be able to deliver scientific support to a management decision on how to proceed based upon the questions raised in the risk profile regarding safety and benefits of the novel plant food.

The risk profile discussed in section 6.1 defines - at least provisional the botanical identity of the source plant, describes the plant tissue(s) intended for food use and identifies the gaps in readily available common and scientific knowledge which prevent the immediate establishment of safe use taking into account the composition or structure of the plant food, the levels of undesirable substances, the known potential for adverse effects in humans, the traditional preparation and cooking methods and the patterns and levels of consumption.

It is foreseeable though that many novel plant foods will have no obvious defined target for the safety assessment, eliminating the possibility to immediately focus the whole safety assessment on one or few identified or known differences. Basically the safety assessment of complex novel foods from conventional plants is more complicated than the safety assessment of foods from GM plants because the novel food in principle is completely new in all traits, while the GM food normally only has been changed in one or few specific trait(s), which then can be the main focus of the safety assessment.

The group, therefore, discussed the kind of a strategy to recommend for the characterisation of safety and benefits of the novel plant food. The proposed scheme is outlined in Figure 2. It builds upon the traditional elements in a safety assessment: hazard identification at the top ("Data from the Risk Profile"), the column at the right leading to characterisation of hazard and benefits, the column at the left leading to the exposure characterisation, and the combined use of the conclusions from those two columns to formulate the final risk characterisation, including its recommendations for further actions to take. The full drawn arrows in Figure 2 indicate the different paths, the case-by-case safety assessment can take depending on the case, while the dotted arrow underlines the iterative element in the assessment process, where new information and additional requests may make the process start over again. 
Figure 2. Safety assessment of novel plant foods and novel plant food ingredients

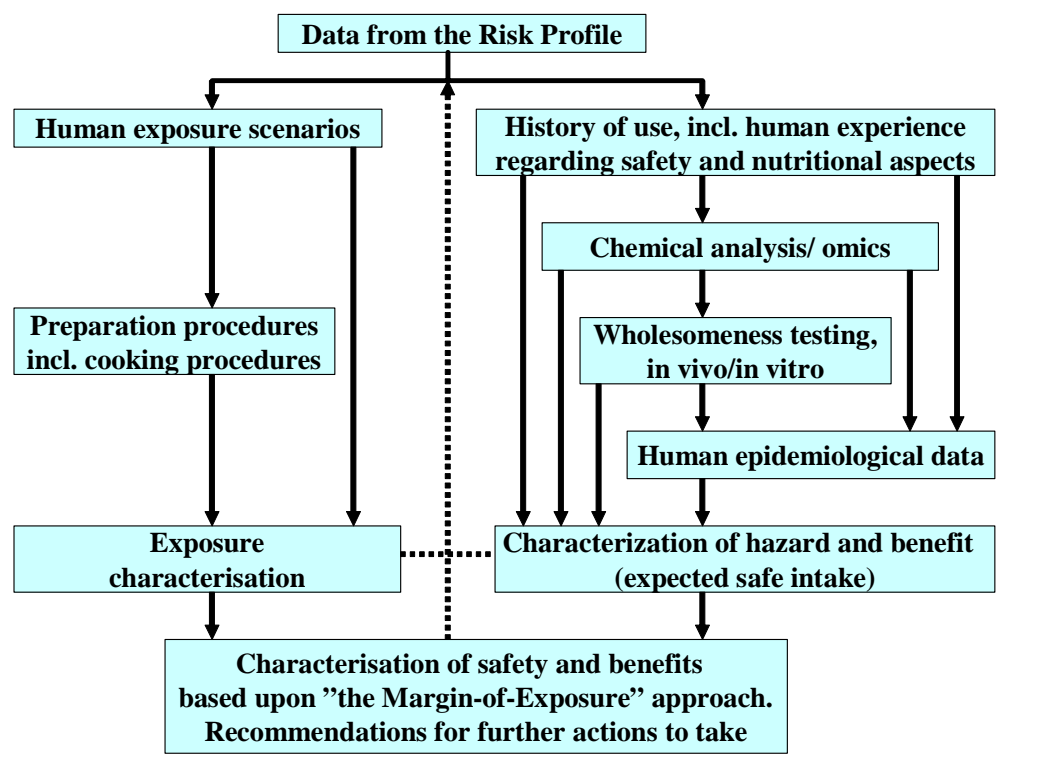

The starting point in the hazard characterisation process in the right column is the history of use, including human experience regarding safety and nutritional aspects. In many cases this information is available only on an informal basis, not in terms of formal scientific publications. Depending on the scientific quality of historical data a scientific characterisation of hazards and benefits can be performed immediately, or the process has to go through chemical analytical stage, through wholesomeness testing in vivo/in vitro, through production of human epidemiological data, as indicated in figure 2.

The detailed approach of the safety assessment may differ between novel food items derived from plants already on the global list for recognised food plants, plants on regional or local or ethnobotanical list(s) somewhere in the world, or plants never before approached for food use in any list. For novel foods derived from tissues of plants already on the global list, there are many sources of information regarding the presence of toxic or antinutritional substances in these food plants which may facilitate or direct the safety assessment. For plants on a regional or local list this may also be the case. For other plants, potentially useful in the food supply but not hitherto used as food to an extent that can justify them being on one of the regional lists, one of the local lists or in one of the ethnobotanical lists, only limited information may be available to guide the first steps in the safety assessment but the claims leading them to become candidates to be put in the category of food plants may give a lead. Also the history of previous use may be of great importance.

The Working Group discussed whether it is possible to recommend a defined set of data requirements as a prerequisite for a safety assessment. An alternative could be a reiterated assessment after each step following 
hierarchical data generation. In the end the Working Group decided to recommend a case-by-case approach as illustrated in figure 2 with the arrows pointing at the alternative pathways in the iterative safety assessment process. The information needed to conclude the premarket assessment may thus in some cases be the information from all the boxes in Figure 2, in other cases just information from some of them depending on the nature of the individual novel food. Typically the hazard characterisation will be concluded through a "weight-of-evidence" procedure, where both qualitative and quantitative aspects of the data findings count. The types of scientific information, which case-by-case form the basis for the hazard characterisation, are discussed in more details in chapter 7.

A main discussion point during the process has been whether in vivo/in vitro safety testing should be performed as a mandatory segment of a premarket safety package or this data generation should only be made on a case-by-case basis. The group discussed the usefulness of the 90-day rat feeding study as a "biological filter" adding safety assurance to the preceding boxes in the assessment scheme and agreed on its usefulness in this respect. Likewise the group discussed the need for formal epidemiological data in each case. In the end the NNT concluded that the degree of safety assurance required or expected by the society is a societal and moral issue and therefore the implementation of mandatory animal safety studies and/or formal human epidemiological data in a fixed premarket data package is a management decision to be taken in the political system.

Regarding the human exposure scenarios, the NNT discussed the expected use or intake of the novel food based on its use as a bulk food for calories and major nutrients for daily intake or a less bulky source for flavours and micronutrients for only occasional use, the influence of preparation and cooking procedures, and the potential for use of probabilistic methods for calculation of intake.

For the final safety/benefit characterisation the Nordic Group agreed not to recommend the use of safety (or uncertainty) factors. Instead the NNT advocates to characterise the safety and potential benefits simply by calculating the Margin-of-Exposure (MoE) as the relation between the safe level of intake determined in the hazard/benefit characterisation, and the actual estimated exposure in humans calculated from intake scenarios foreseen in exposure characterisation.

Another management decision is whether to place the value for the MoE on a label of the novel food when it is marketed. When communicated to the consumer on the label together with the information on how to prepare this novel plant food for eating, the value of the MoE will allow each user group to decide on the composition of the diet which fit him or her best in terms of securing him or her the most safe diet, the most nutritious diet or the most health promotional diet, or just a diet 
which complies with his or hers personal values or expectation for good food.

\subsection{Conclusions on the assessment of novelty and safety}

This chapter recommends the division of plant foods in those accepted on a worldwide level, and in those considered non-traditional at a worldwide level. Many of those plant foods considered non-traditional on a worldwide level might be considered traditional foods on a regional level in one or more regions, while they remain non-traditional as food sources in the other regions and therefore may be considered novel there. Likewise those remaining non-traditional at the regional level might be considered traditional at the local level within the region, or being traditional for ethnic group within the region or the local level.

The first step of such a process will be to assess the novelty of the food through the establishment of a risk profile, and afterwards as a second step assess the safety of the novel food going through a risk characterisation procedure. Each step follows a separate decision tree approach.

For the assessment of novelty at the first step this chapter recommends the development of a set of positive lists containing the plants accepted as sources of food either on the global level or on the regional/local level or by special ethnic groups. The global list, and the cluster of regional, local and ethnobotanical lists will - when developed - present the overall human experience with plant foods. When a plant food for the first time is going to be assessed for novelty on a regional or local basis, the other regional, local and ethnobotanical positive lists can be visited to see if this newcomer on the food market really raises new questions or it can be considered acceptable based on its usage elsewhere.

The assessment of safety at the second step for those plant foods considered novel at the global, regional or local level the history of use is the first crucial element. The quality and quantity of the scientific data for the individual plant food in the databases behind the global, regional, local and ethnobotanical lists determines whether the history of safe use can be established immediately and a risk assessment concluded, or additional animal data, in-vitro data, human data and/or intake data is needed to the establishment of safety of this novel food based on its Margin-ofExposure. The tools needed for this assessment is described in the next chapter. 


\section{Different tools applicable for premarket analysis}

Both the European and the Australian/New Zealand Novel Food Regulations demand a pre-market notification or assessment and acceptance/approval of exotic fruits and vegetables (if they are considered novel in accordance with the relevant definition) before the products are placed on the market. The intention of the pre-market notification is to give the relevant authority the possibility to assess the potential risks of using the suggested novel food.

The aim of the premarket assessment of novel foods is to demonstrate that the novel food is as safe as traditional counterparts or food items to be replaced in the diet by the introduction of this novel food and as such does not introduce any additional or new risks to the health of the consumer (Howlett et al., 2003; Cellini et al., 2004).

Most of the foods commonly eaten have never been investigated systematically with respect to their impact on consumer health. Generally, they are considered as safe unless a significant risk has been identified in humans. However, it should be emphasised that the absence of evidence of toxicity is not the same as evidence of safety. Without specific investigations, only acute and severe adverse effects are likely to be identified. The demonstration of the safety of a food as part of the overall diet requires specific intake information together with data on health impact. Although case reports, epidemiological observations, and/or experimental human studies may exist for a restricted number of foods (e.g. coffee), this type of information related to human health is lacking for most food plants (Schilter et al, 2003).

The nature and extent of the toxicological data set required to assess the potential risk associated with a novel food depends largely on the nature of the novel food. Obviously, a plant that has never been consumed before will put another challenge for the risk assessor than a novel food very much resembling a traditional food we have a long experience of consuming without health problems.

There are many factors of importance when assessing the safety of novel foods. Howlett and co-workers (2003) stressed the fact that the first step in any safety assessment of novel foods comprises the collation and in-depth appraisal of information on the origin of the food material, production, composition, nutritional characteristics, history of previous human exposure and anticipated use of the material, including required cooking procedures. This exercise should give a considerable amount of data that may allow a primary evaluation prior to initiating testing for 
toxicity and other end points, and may in some cases be sufficient to permit a conclusion as to safety. This could, for example, be the case for exotic fruits and vegetables that have a vast history of safe consumption outside the European Community. In other cases it may serve to characterise the novel food and to identify knowledge gaps and likely areas of concern. It should also provide a basis to define the extent and objectives of any additional studies that will have significance for the safety assessment (Howlett et al., 2003). Additional information required could be data from toxicity studies in animals, toxicity of any related substances or foods, and any known cases of adverse effects in humans (FSANZ, 2004).

This chapter describes some of the main tools, which are applicable for the safety assessment of exotic fruits and vegetables prior to marketing.

\subsection{Characterisation of a plant food}

The precise specification of the plant food both from a botanical and chemical point of view is the most important template for trustworthy risk assessment.

\subsubsection{Botanical characterisation}

With regard to exotic fruits and vegetables and their products, which have not earlier been consumed to a significant degree within a region, a complete scientific taxonomic identification will considerably speed up the identification of possible close relatives to the plant in question, thereby facilitating a prediction of chemical composition and an assessment of safety and the nutritional aspects.

Taxonomic identity of the plant should be given according to internationally accepted principles, including complete scientific name (family name, genus, species, author name, subspecies, cultivar/breeding line) and common name (König et al., 2004). The sexually compatible wild relatives and their habitats have to be described.

One example to demonstrate the necessity of giving extensive information about the identity of a plant is that all known cabbages, whether red cabbage, Chinese cabbage, pak choi, Brussels sprouts or broccoli belong to the same species Brassica oleracea. One group of chemical constituents of Brassicas, the glucosinolates, has been claimed to give rise to adverse as well as health promoting effects. The glucosinolate composition and not least the concentrations vary considerably from one cultivar to the other. Also within cultivars the level of glucosinolates produced may differ e.g. influenced by several environmental factors, including growing conditions. 
Another example would be a species where 'ecotypes' occur and these differ with regard to chemical composition. Although not being a likely candidate as food plant, the woody nightshade (Solanum dulcamara) could stand as an example. Depending on where in Europe samples of this species are collected the likelihood of collecting a plant with a particular composition of glycoalkaloids change (Andersson, 1999).

It is also important to give information about what part of the plant is intended for food use. The chemical composition often varies substantially between different plant parts. For many food plants only a single plant part is consumed and only that part of the plant is considered safe to eat, e.g. tubers of the potato plant (Solanum tuberosum L.).

Additional information to aid the risk assessment could be whether the novel food is collected from nature or the plant is bred in a specific way. If agricultural practices are important, these should be adequately described.

The importance of correct botanical characterisation is underlined by the problems of mis-identification e.g. the intoxication caused by using Japanese star anise or bastard anise (Illicium anisatum L.) instead of the normally used spice Chinese star anise (Illicium verum L.) in a herbal tea in the Netherlands (Johanns et al., 2002).

On the top of its botanical identity the individual varieties of the fruits and vegetables are characterised by their appearance, size, shape, colour, texture, smell and taste. These parameters are of great importance for the plant breeders, because these parameters also are determinants of the success of the products with the consumers.

\subsubsection{Chemical characterisation}

In most cases each cultivar is delivering one kind of food, a vegetable, a fruit, a grain etc., and this plant food is nutritionally characterized by its content of macronutrients, like protein, fats and carbohydrates, fibres, and micronutrients, like vitamins and minerals. The chemical characterization may be further specified by information on the content of specific proteins, individual amino acids, fraction of oils, individual fatty acids, simple and complex carbohydrate, individual sugars and fibres.

The chemical characterization of the plant food both from a regulatory point of view and a consumer point of view is most perfectly performed in the OECD Consensus Documents, specifically developed to characterize individual plant food items. An extract of the foreword of the OECD Consensus Document on Compositional Considerations for New Varieties of Maize (Zea Mays) exemplifies this (OECD, 2002):

\footnotetext{
“These consensus documents contain information for use during the regulatory assessment of a particular food/feed product. In the area of food and feed safety, consensus documents are being published on the nutrients, anti-nutrients or toxi-
} 
cants, information of its use as a food/feed and other relevant information. This consensus document addresses compositional considerations for new varieties of maize by identifying the key food and feed nutrients, anti-nutrients and secondary plant metabolites. A general description of these components is provided. Also included are considerations to be taken when assessing new maize varieties, including suggested analyses.”

And further in the preamble:

\footnotetext{
"These data are used to identify similarities and differences following a comparative approach as part of a food and feed safety assessment. They should be useful to the development of guidelines, both national and international and to encourage information sharing among OECD Member countries.”
}

These documents present an excellent background material also for the development of the plant food lists recommended in this report (See chapter 6).

Seen from a plant perspective the chemical constituents of plants can arbitrarily be divided into two classes according to function. Those known as primary plant metabolites are forming building structures and internal transport systems in the plants or contributing to the energy production in the plants. The secondary metabolites are not essential to the basic metabolism of plants. They are formed from the primary metabolites and occur in many different chemical forms often specific to a single species or a group of related species, and sometimes as a response to an inducer, e.g. a specific environmental condition or an infection or as a response to attacking insects. For a long time the function of most secondary metabolites have been poorly understood. However, our understanding of their role in the plants has increased during later years. Many secondary metabolites have a role in the plants defence machinery, others may be involved in metabolic processes or be created as by-products in these processes (Hegarty et al., 2001). Because of these roles of primary and secondary metabolites in the plants, primary metabolites are most likely to have nutritional importance in the consumer, whereas secondary metabolites are relatively more likely to give rise to adverse effects and to the flavours.

An example of a systematic evaluation of consumed plants could be the study of Hegarty and co-workers (2001). These investigators undertook a study of secondary metabolites in Australian bushfoods, assuming these constituents have the strongest potential for toxicity due to the Australian diet. In this study they screened for the presence/absence of alkaloids, cyanogens, oxalates and saponins in fresh and frozen samples of the major bushfood species, and determined the amounts of these compounds present in the foods. The aim of the study was to broaden the knowledge about the chemistry of native plant foods, describe their history of use in the traditional communities, explore the potential to use 
these foods as a resource for commercial exploration, as well as to indicate areas where further research is required.

It is obvious that knowledge is required on the types and amounts of nutrients and non-nutrients (primarily primary metabolites), vitamins, and minerals present in a novel food. In addition information is needed on the presence of potential anti-nutrients and natural toxicants. It might also be necessary to identify if the plant is particularly prone to become enriched by minerals and environmental pollutants, as for example selenium and heavy metals, respectively. If knowledge is scarce about the plant species in question, it has been suggested that information on the presence of natural toxins and allergens in related plant species may be used as guidance for identification of classes of compounds most likely to occur in the investigated species (Howlett et al., 2003). If concern with respect to safety of a novel fruit or vegetable has been raised on such a basis, chemical analyses should form the core information on which to base the decision on the kind of further action to take e.g. performance of toxicological investigations.

This hierarchical approach has been taken in the EU AIR project NETTOX, 1995-1997, which compiled and evaluated data on natural food plant toxicants in the European food supply in order to assess the human health risk of consuming plants with such toxicants, and to identify strategies to minimize such risks (NETTOX, 1998). Due to variation in the quality of the compositional data and the safety data NETTOX had to develop a data quality assessment system, which graded the compositional data in three classes and the toxicological data in four classes based on their scientific quality. Furthermore the LanguaL food description system was taken on board to enhance the compatibility between the NETTOX data and the national food consumption databases and thereby facilitate the risk assessment based upon hazard and exposure (NETTOX, 1998).

A situation that might pertain particularly often to novel foods is that chemical analytical standards for specific compounds are not available and, therefore, require chemical synthesis, which may substantially increase the cost of the analytical exercise but may also produce material required for subsequent toxicity testing. If an extensive chemical analysis does not identify compounds that would trigger additional studies, this type of information may be the only data that are needed for the hazard characterisation (See figure 2). An example could be a novel food made from a plant part not previously consumed from an otherwise well established plant food. 


\subsection{History of use as food}

Describing the history of use as food of a novel plant food is an important introductory part of the safety assessment. In a specific region the history of use as food of exotic fruits and vegetables varies from foods from plants that have never been consumed before, to plant foods that are well known from other regions and with a long history of use and no reported negative effects.

Therefore the novelty of food plants is determined by the lack of an established documented history of use as food in a specified geographical region. For the determination of novelty in this respect the lists discussed in chapter 5 are of crucial importance. These positive lists with plants having a history of use as food can only be established based upon global, regional, and local efforts resulting in the establishment of lists, preferentially based on databases documenting the claim that the particular plant food with its botanical and chemical identity has a history of use as food in the particular regional or local environment. Every list is to be defined by the geographical area it covers. When a plant food is presented as novel in a region, it may be followed by the information on history of use as food in another region taken from that regions positive list.

The term "history of use as food" covers a description of the use in different defined geographical areas with information on intake levels, intake patterns, years on the market, different preparation and handling methods and impact on human health, while the term "history of safe use as food" includes a scientific evaluation of the information and implies that this evaluation can lead to a conclusion about its safe use.

When using the term "history of safe use as food" for the conclusion rather than "history of use as food", it may be defined as follows:

"History of safe use" for a food is a term for the qualified presumption of safety, where there is evidence for its safety from compositional data and from experience as an ongoing part of the diet for a number of generations in a large, genetically diverse population. This presumption is for a certain context of use (conditions of use, such as part of the plant used and required processing) and allows for minor population predispositions such as intolerance and allergenicity (S.Page, WHO: personal communication 2005).

Instead of history of use the term "traditional use" has been suggested. The concept "traditional use" is based upon knowledge and experience in the heritage of a population/culture (but may have very limited scientific documentation), while well-established use in general is based on traditional use supplemented with available scientific data (Bast et al., 2002). Traditional use may provide information on acute toxicity but is unlikely to provide information on chronic toxicity. Information from traditional use will also be influenced by the availability of food, the general health of a particular population, and the available health care and health monitoring facilities (Bast et al., 2002). 
In addressing the history of safe use, history of use, traditional use, and well-established use of plant-derived foods, a description of the novel food together with information respecting its development, details of major change(s), if any, details of the method by which it is manufactured, prepared, preserved, packaged and stored, information regarding its intended use and directions for its preparation, information respecting its history of use elsewhere, and if applicable, information relied on to establish that the novel food is safe for consumption and information regarding the estimated levels of consumption by consumers of the novel food. The safe use of plant foods sometimes depends on special pre-treatment established by "custom and practice" that renders it palatable and safe (König et al., 2004). This situation is illustrated by the red kidney bean example and to some extent the lupin example in chapter 4.

In the description of history of use it is important to remember the context in which the history of use is developed, namely on the background of the traditional dietary pattern in the region. From a regulatory point of view, a region would appropriately be defined by country or community borders e.g. EU, but it could also be defined as WHO does in the Global Environment Monitoring System - Food Contamination Monitoring and Assessment Programme (GEMS/Food) (WHO 2003), where the global dietary patterns have been limited to five regional dietary patterns, namely the Middle Eastern, the Far Eastern, the African, the Latin American, and the European pattern. The "European" diet includes nonEuropean countries with European-type diets, such as Australia, Canada and the USA. The GEMS/Food document lists about 250 raw and semiprocessed food items of both plant and animal origin with average per capita food consumption for each of the five regions. Furthermore by using a cluster analysis approach, thirteen GEMS/Food Consumption Cluster Diets have been produced based on FAO Food Balance Sheets (http://www.who.int/foodsafety/chem/gems/en/print.html).Although these diets were developed with the purpose to predict the dietary exposure to radionuclide contamination and have been used by the Joint FAO/WHO Expert Committees for evaluating food additives or pesticides residues, these GEMS diets could equally be used to define regions and to develop regional positive lists for plant foods with their individual history of use, consumption pattern or expected intake level.

Additional important data to support a conclusion on a history of safe use of a novel plant food being a traditional food in other parts of the world could be information on serving sizes/daily intake levels, purpose of consumption, possible target population(s), and known potential problems (precautions, contraindications, adverse effects) (ILSI, 2003). As far as possible, published data should be collected and evaluated for their quality and usefulness at the regional or local level, because the national/regional literature in national/regional languages may contain a wealth of information not accessible via global data banks. It is extremely 
important if such data could be inserted in databases developed to support the regional or local positive lists suggested to be developed for the food plants. This also means that the pre-existence of such plant lists in a region will be able to support applicants who wants to introduce such a plant food in a region, where it appears to be considered a novel food. Other sources, including data collection on site, may also be helpful to provide facts and/or guidance for the assessment (Howlett et al., 2003).

Also of importance when addressing the history of use of a plant food is to take into consideration that traditional breeding constantly may bring different varieties of a food plant to the market. The food derived from such varieties may vary a lot in composition, and information covering the history of use for these different varieties are strongly needed to facilitate the process of establishing a history of safe use.

Information on local claims or perception of any health effects connected to the plant food may be of great help in assessing its safety. A plant that previously has been used for medicinal purposes or has a folk remedy reputation in various parts of the world, whether or not consumed as food (or botanical products/extracts covered by the definition of food), may have some physiological effects on health that need to be considered not only as beneficial but also from a safety point of view (Schilter et al., 2003).

Most of the exotic fruits and vegetables considered novel in one region might be well known with a history of use, even safe use, in another region. On this background the concept of positive lists for global, regional, local and ethnobotanical food plants is introduced in chapter 6.

Such a positive list shall describe the individual plant food and identify the source plant. Most appropriate the lists are based on the name of the food plant, which is then subdivided into the individual plant foods derived from that plant. The description shall include the plant names and synonyms for exact identification (including language equivalents from different parts of the World and the standardized names from the International Standards, ISO), specific plant part(s) analysed and the analytical results, sample size, year of sampling. It should also include description of maturity, cultivar, growing conditions, storage conditions, usual processing and food preparation procedures, country of origin, region of origin, season of harvesting. The compositional data of the edible parts shall contain information regarding macro- and micronutrients, inherent toxicants and antinutrients. The individual plant monograph should also contain references to the scientific literature covering nutritional, toxicological and health promotional appraisal. When such lists have been established world wide for each region or each national or economical community, which fit the best, everyone can take the advantage of the lists of each other for the assessment first of the novelty, and later of the safety of the different plant foods. The lists are foreseen to facilitate the global trade with exotic plant foods, and the regional and local accep- 
tance - and thereby introduction - of regionally novel plant foods, which turn out to have a history of safe use in other regions.

\subsection{Animal studies in the safety testing of novel plant foods}

Toxicological studies in experimental animals have historically been developed for assessing discrete chemical substances. Experimental studies on rodents are indispensable in the testing battery for safety assessment of compounds such as food additives, pesticides, pharmaceuticals and industrial chemicals (WHO, 1987, 1999). Therefore, there are internationally accepted standard approaches for such tests (OECD 1995). In most cases, the test substance is well characterised, of known purity, of no nutritional value and human exposure is generally low. It is therefore relatively straightforward to feed such compounds to animals at a range of doses, some several orders of magnitude greater than the expected human exposure levels, in order to identify any potential adverse effects of importance to humans. When an adverse non-cancer effect has been identified, the animal study allows the establishment of the highest exposure level at which no overt toxicity occur, the so-called No-ObservedAdverse-Effect-Level or NOAEL (WHO, 1987 and 1999; ACNFP, 1999; Howlett et al. 2003). The NOAEL is subsequently used to calculate the safe level of intake, the Acceptable-Daily-Intake or ADI.

In contrast, novel foods from plants are usually complex mixtures of various compounds, many with the potential to vary in concentration in the individual plant food depending on the plant variety used and the growth conditions. Due to the bulky nature of the food itself and the effect on satiety whole foods can only be fed to animals at low multiples of the amounts that might be present in the human diet. Toxic compounds embedded in the novel food may therefore never reach a level in animal studies at which the toxic potential of a constituent is revealed. In addition, a key factor to consider in conducting animal studies on foods is the nutritional composition of the feed. Increasing the fraction of the tested food in the feed above a particular level may distort the nutritional balance of the diet, and might induce adverse effects which are not related directly to the material itself but to induced nutritional imbalance. Picking up any potential adverse effects and relating these conclusively to an individual characteristic of the food can therefore be extremely difficult, unless the studies are well designed with the animal diets well adjusted (ACNFP, 1999; Dybing et al. 2002; Knudsen and Poulsen, 2005). A sensitive and specific approach is to combine the testing of individual, pivotal compound(s) identified in the novel food with the testing of the whole food, eventually spiked with the pivotal compound(s), in separate studies (Knudsen and Poulsen, 2005). 
The objective of any toxicity testing programmes for novel foods should contribute to the identification of a potential hazard, its doseresponse relationship, and the establishment of a reasonable certainty that no harm will result from its intended use as food (Howlett et al., 2003). If applicable, the safety of the novel product should always be compared with the safety of the foods it will replace (Howlett et al., 2003). Selecting the battery of tests required to establish the safety of novel foods has to be done case-by-case, not least because of the huge variation possible in the extent of novelty of the novel food as compared to traditional foods. Therefore, it is not possible to set general rules specifying a definitive list of studies either for single defined substances or for whole foods. In deciding which studies are necessary and appropriate for a particular novel food the guiding principle should be that the studies address aspects of toxicity not addressed elsewhere by the information already available and that they are capable of doing so in an unambiguous fashion. The task to identify suitable toxicity studies may sometimes be very difficult. If the toxicity studies are not designed and undertaken with clear and achievable objectives in mind, it is unlikely that they will contribute positively to the safety assessment (Howlett et al., 2003).

Considerations regarding the need for doing animal toxicity studies on the novel plant food in the premarket situation will most likely focus on two main issues: potential toxicity of inherent chemical entities of unknown nature identified in the novel food and the safety of the whole food understood as the absence of adverse effects in a repeated dose feeding study in rodents or pigs.

The toxicity testing of distinct chemical entities of course depends upon the availability of those chemicals in isolated form to be mixed in the animal feed. Such a testing procedure will normally start with an acute toxicity testing followed by a 28-day rodent feeding study (Knudsen and Poulsen, 2005). In practice, if toxicokinetic studies are to be done, they will only be possible for defined chemicals and simple mixtures and are not useful for complete foods, unless it focuses on a defined constituent (Howlett et al., 2003).

In cases where a repeated dose animal feeding study on the whole food is likely to provide useful information in the premarket situation, a 90-day subchronic toxicity study in a rodent species is likely to be a study of minimum reasonable duration, and may often be of sufficient duration to provide data adequate for use in evaluating safety or to determine whether there is need for further studies. The scope of the animal toxicity study should normally be to include the full range of experimental parameters appropriate for this type of protocol (Howlett et al., 2003). To ensure the scientific validity of such a rodent study, great attention and focus should be devoted to the design of the diet imbedding the novel food (Knudsen and Poulsen, 2005). It is suggested that a 90-day study in pigs may provide a better biological filter in the safeguard of human 
health due to the more humanlike design of the gastrointestinal tract in this animal (S. Page, WHO, personal communication).

A main challenge in the optimal design of repeated dose animal feeding studies for the safety assessment is the identification of appropriate comparators to the novel foods for the control group. In some cases the choice is straightforward with the selection of fruits or vegetables closely related to the novel ones. In other cases the comparator may be the food item, which is going to be replaced in the human diet by the novel food. Finally in some cases no comparator can be identified and the novel food has to be assessed on its own. This may be the case for many novel foods where it is not clear what specific food or group of food it will replace.

The levels of the novel food to be incorporated in the animal diet may either be one level, namely the highest level tolerated (calculated from a short-term study and the compositional data) when there is a good comparator, or two levels, namely comparable to expected human intake plus the highest level tolerated, when there is no comparator. In the first case the good comparator allows direct calculation of the Margin-of-Exposure between the novel plant food and the known (safe) intake of the comparator, while the calculation in the second case depends upon the existence of experimental data illustrating that the expected human intake is safe (within the remit of the study).

If the repeated dose feeding study becomes the pivotal study for the hazard characterisation, the dose level(s) used will be the one to compare with the expected human intake established in the exposure characterisation. The Margin-of-Exposure established in this manner then becomes the basis for the risk characterisation.

\subsection{Testing of novel foods in in vitro tests for toxicity and mutagenicity}

In vitro methods are relatively cheap and have a high throughput. However, results from in vitro tests may only be indicative of toxic effects as these test systems rely on reconstituted purified proteins or cell components, or immortalised cell lines cultured artificially. They are only to a limited extent representative of the functioning of such cell components or cells in living organisms. In vivo tests are therefore required to confirm observations on absence or presence of toxic activity from in vitro tests (König et al., 2004).

In vitro genotoxicity studies will often be useful only for defined chemicals or simple mixtures. In general, the testing of whole food extracts in genotoxicity studies is inappropriate as the experimental condition is likely to result in artefacts making interpretation difficult. Based on knowledge from the literature, however, single components of complex novel foods may be identified and could be investigated in such 
studies. For complex foods, some assurance of the absence of a potential for genotoxicity may be gained by appropriate "directed" investigations of bone marrow cells or peripheral lymphocytes undertaken as an additional complementary element of repeated feeding studies in rodents (Howlett et al., 2003).

In the context of novel foods, it should be recognised that many botanical materials contain naturally occurring compounds that may test positive in genotoxicity tests in vitro. Although such results are indicative of that botanical material having a genotoxic effect, this might not necessarily be the case. Most compounds that have turned out positive in in vitro tests have been negative in in vivo assays performed to confirm that mutations are induced also during this condition (Bast et al., 2002). Positive in vitro results should, however, be investigated with in vivo studies, unless the positive result can be attributed to an identified component known to be safe in vivo (EMEA Ad hoc Working Group on Herbal Medicinal Products, 1999).

\subsection{Test of novel foods for allergenicity}

Food allergies are adverse reactions to otherwise harmless food or food components characterized by a response of the body's immune system to specific protein(s) in foods (WHO/FAO, 2001). This response could be looked upon as abnormal, as only a minor fraction of the population (with disposition) would react in this way to the protein. The prevalence of food allergy in the Western world is up to $8 \%$ in children but only $2 \%$ in adults (Sampson and Burks 1996). Although food allergy is 3.6 times more frequent in children compared to adults it is confirmed that there is a preponderance of severe cases in adults (Morisset et al., 2003).

The most common type of food allergy is mediated by allergenspecific immunoglobulin E (IgE) antibodies. IgE-mediated reactions are known as immediate hypersensitivity reactions because symptoms occur within minutes to a few hours after ingestion of the offending food. IgEmediated reactions may occur to pollens, mould spores, animal dander, insect venoms and other environmental stimuli as well as to foods. In IgE-mediated food allergies, exposure to a specific food and its proteins in addition to reacting with antibodies elicits further development of food allergen-specific IgE antibodies.

True food allergies also encompass delayed hypersensitivity reactions whose mechanisms are less clear. Such reactions include cell-mediated reactions that involve sensitised lymphocytes in tissues rather than antibodies. In cell-mediated reactions, the onset of symptoms occurs more than 8 hours after ingestion of the offending food (FAO/WHO, 2001).

It is not realistic to strive for absolute absence of risk for allergenicity. Instead, the general point of view is that the aim should be to ensure that a 
novel food is at least as safe as its traditional counterpart, that food it will substitute in the diet. With this in mind, the objective with regard to allergenicity is to establish whether the novel food has an increased potential to induce sensitisation or to elicit allergic reactions than the food product it is compared to (Kimber and Dearman, 2002). Recommendation for labelling should be part of the consideration for reducing the risk.

Food allergies are caused by a wide variety of foods of which the most important plant products are peanuts, soybeans, wheat and tree nuts. Allergic reactions to fresh fruits and vegetables may also be expressed as an oral allergy syndrome (OAS). Symptoms of OAS are typically mild, and mostly confined to the oropharyngeal region. Some of the most significant allergens from foods giving rise to OAS are unstable to heating and digestion. However, OAS in patients allergic to fruits and vegetables may, in some individuals, be followed by a systemic reaction (FAO/WHO, 2001).

Novel food items may give rise to cross-reactivity to well-known food or pollen allergens. Such cross-reactions between new and well-known allergens can be studied by various methods: serological methods, skin prick tests, or by open challenge or double blind placebo controlled food challenge of allergic patients as was done with the nangai nut in the studies by Sten et al. (2002) and Fremont et al. (2001).

In the rare cases when the amino acid sequence of proteins in novel foods are known, these sequences could be tested by bioinformatic methods to predict whether the protein is likely to be an allergen or not (Codex Alimentarius 2004). As none of the test methods available today is able to predict whether a protein is an allergen or not in the absence of the amino acid sequence, which is often the case for proteins in novel foods, there is a growing consensus that an appropriate validated animal model for characterisation of allergenic potential is needed (FAO/WHO, 2001; König et al., 2004). At present animal models for predicting and characterising (protein) allergenicity are based upon assessment of induced antibody responses and/or the frequency of responders in the test groups. A continued research into the immunobiology of protein allergy with particular emphasis on the identification of molecular markers that can be used to distinguish protein allergens from non-sensitising proteins is required (König et al., 2004). The most appropriate animal models for allergenicity available should be evaluated fully with a range of sensitising (weak and strong) and non-sensitising proteins so that their sensitivity and selectivity can be assessed (König et al., 2004).

\subsection{New "omics" methods}

Although many issues remain to be resolved and significant challenges lie ahead, it is expected that information obtained from genomics, tran- 
scriptomics, proteomics, and in particular metabolomics will be extremely useful in the identification, characterisation and profiling of the novel food itself as well as the plant as the source for the novel food.

It can also be predicted that particularly metabolomics will have a significant impact on the case-by-case approach to be taken in toxicology in the future. One can predict that the information gathered from experiments using these technologies will form the basis for improved methods to assess the impact of chemicals on human health (Eisenbrand et al., 2002) but this is an issue with implications much broader than just safety testing of novel plant foods.

\subsection{Human data}

Human experience, but normally not formal human scientific studies, is an essential part of the data collection in the history of use. The human experience on the intake of a certain food in a region different from the one, which has deemed the food to be a novel food, is normally just an empirical observation that the food in question has been eaten in this and this way for generations in that region. It will normally be coupled with information on how it is prepared, how it is eaten and how much, and whether the food in question has had any special claims linked to it. This kind of information is not following the rules for the performance of scientific studies.

There is no doubt that clinical studies in humans as well as epidemiological data from retrospective and prospective human studies are likely to achieve a much greater role in assessment of the safety of novel foods than in other areas of safety testing. Provided the in vivo animal studies demonstrate no adverse effects, human studies should be considered in order to confirm the absence of metabolic and physiological disturbances. A greater emphasis could be placed on availability of toxicokinetic studies to complement animal data. Additional mechanistic studies may be appropriate to investigate unexpected adverse effects. Whether specific subgroups of a population might be more sensitive to a potential hazard associated with a food might be studied in more details. More susceptible subgroups of a healthy population to certain risks often include infants, pregnant women, nursing mothers, and possibly the elderly. In many cases such studies can be performed without ethical concerns in regions where the food in question is already eaten and therefore not considered novel.

Studies in humans should not form a routine part of the premarket safety assessment but they can contribute to it by providing confirmation of nutritional quality and the absence of adverse effects, which has been ruled out by previous considerations. Population studies carried out postlaunch in the target group of the general population (i.e. after the satisfac- 
tory completion of a safety assessment) may be helpful in providing confirmation of anticipated usage patterns and exposure levels. Human studies may also be used to examine bioavailability or human metabolism when the safety of a compound is known. For novel plant foods already eaten by humans somewhere, there will be no ethical constrains about performing the relevant human studies in such places.

\subsection{Nutritional aspects}

An evaluation of the nutritional characteristics of a novel food is an important component of the assessment process. The novel food should be evaluated from the perspective of its likely impact on the human diet to provide assurance that its introduction into the food chain will not cause adverse effects through nutritional inadequacy or excess. A basis for this evaluation may be provided by the information embedded in the history of use or it may be a combination of analytical data, claims or recommendations intended for the marketing of the novel food and specifically designed human studies (see the section above).

Key components of novel foods are in most cases nutrients in the particular food that may have a substantial nutritional impact on the consumer. These constituents may be macro-nutrients (fats, proteins, carbohydrates) or micro-nutrients (minerals and vitamins) (König et al., 2004). Novel foods may also contain anti-nutrients that inhibit or block pathways in the human metabolism, or impair digestion. Anti-nutrients may reduce nutrient utilisation, typically proteins, vitamins, or minerals, thereby decreasing the nutritive value of foods (König et al., 2004).

\subsection{Exposure assessment}

The exposure assessment of novel fruits and vegetables (as of any other novel food) should be undertaken to ensure an adequate Margin-ofExposure for users under the intended conditions of use.

The intended or anticipated use of the exotic fruit or vegetable will provide information of absolute necessity for the assessment of whether the use will be safe or constitute a risk. It is of great importance for the outcome of the risk characterisation whether the novel food is intended or anticipated to be used only a few times throughout a lifetime or is it foreseen to be consumed in kilos per month. Often the sales arguments for the novel food and its price will tell if the novel food mainly preserves a good health or prevent chronic diseases in smaller dosages, is a new interesting spice for food preparation, or it really is meant to replace a major traditional food component, and thereby the volume to be sold. Whilst experience from the region from which the exotic fruit or vegetable ori- 
gins surely can provide helpful information, consumption patterns must be considered in the local context of the novel use proposed (Howlett et al., 2003). A food traditionally consumed only occasionally or exclusively in combination with another material may cause problems when consumed in larger quantities or in a different combination (Howlett et al., 2003).

The exposure assessment should also consider the appropriate ways of preparing and cooking the novel plant food. Some are to be eaten raw, some are to be milled to flour and go through baking processes, some are to be peeled and cooked, some are to be extracted, treated with acids or bases, dried and fried. All these processes greatly influence the contents and digestive availability of inherent toxicants, macro- and micronutrients of the individual novel food as assessed in the hazard characterisation.

The primary objective of a food exposure assessment is to estimate the aggregate intake levels of the particular food or food constituent. This includes the determination of estimated daily intake and the theoretical maximum daily per capita intake (König et al., 2004). Exposure assessments to specific foods may often lack precision because of a wide interindividual variation in food consumption within and across different populations. In consequence, it is important to gather information on food consumption both at the population level (per capita intake) and at the individual level.

Furthermore, estimates should take into account variation amongst demographic subgroups of a population. Thus, it may be necessary to stratify dietary intake assessments of specific foods according to age, gender, socio-economic status, location, and ethnic origin depending on the outcome of the human studies on the novel food in question.

New probabilistic tools allow a better and more realistic estimation of the likelihood of extreme exposures.

\subsection{Risk characterization and safety}

The risk characterisation is based upon the outcome of the hazard characterisation and the exposure assessment. It does assess the safety and nutritional properties of the defined plant food characterised by its botanical origin and chemical composition. The NNT recommends that the risk characterisation or - more correctly - the safety of the individual novel food is defined by its Margin-of-Exposure, which is calculated from the estimated daily safe intake divided by the likely human daily exposure. This value can then be used by the risk managers to guide the further decisions on the use of the novel plant food in the general food supply, and - if properly indicated at the food - by the individual consumer to 
guide his/her choice for proper food that meets the individual expectations and needs.

\subsection{Conclusions on tools applicable for premarket analysis}

The instruments and the concepts in the toolbox are not new but taken over from the fields of chemical safety and nutritional assessment to the field of whole food assessment. Some of them are already in the process of being readjusted and refined for the use in the safety assessment of novel foods.

For the assessment of the safety of novel plant foods the most important instruments prioritised by the NNT right now are the precise characterisation of the plant food based upon the botanical characterisation and the chemical characterisation as well as its history of use, mainly based on the development and combined use of the proposed global list, regional/local lists and ethnobotanical lists based upon quality assessed data on exposure and safety. Today such lists only exist to a very limited extent, and the data supporting the existing ones is often of uncertain origin with limited quality assurance linked to it. This is a major obstacle to the global trade with novel plant foods because the information from trustworthy lists in many cases will be sufficient to establish the history of safe use as guidance for the hazard characterization in a region where the food has not been eaten before. If the botanical characterisation and the chemical characterisation are well defined and the history of safe use can be established by the competent authorities, there may be no need to request animal studies and/or human studies in such a case.

The section on animal studies concludes that well planned and well performed animal studies with strong focus on the design of the test diet are able to act as an efficient biological filter in the premarket situation for genuine novel foods. Clinical studies and formal epidemiological studies in humans are relevant as follow-up of the premarket situation, when a history of safe use cannot be established based upon available data and when the safety established in in-vivo studies diminishes the ethical barrier for doing human studies. 



\section{A plea for a continued interactive exchange of concepts and ideas between management and science in this field}

Plant foods that are traditional in one country or region may be novel in another country or region. The EU legislation makes it necessary to distinguish between the traditional plant foods on one side and the novel plant foods on the other side, because the novel plant foods according to the EU legislation need to go through a premarket assessment procedure. Since the EU legislation is pretty new, from 1997, the legal and scientific instruments for this process are not fully developed yet, and an interactive exchange of concepts and ideas between management and science is urgently needed.

On this background the present report has developed a proposal for a set of criteria for determining if a plant food is traditional or novel and a proposal for an approach for the safety assessment of such plant foods with no or limited documented history of safe consumption as presented in the preceding sections.

During the development of these proposals a number of issues has underlined the need for continuation of the interactive process between science and management. As discussed below, there are still many unique, unripe concepts in the process, which need attention both from the scientific and managerial angle, and many new instruments still need to be developed and refined in science and management to make the process a success for all.

Chapter 2 presents the regulations of novel food in Canada, Australia/New Zealand and Europe where the exotic fruit and vegetables may be included in the respective definitions. Although these regulations make sense in their purpose to protect consumers against new foods with potential adverse effects, they all have the same inherent problem, namely that there in the practical execution of the legislation is quite a room for the individual interpretation of the term "novel" and for the case-by-case decision on whether or not a plant food fall under the legislation.

From the historical experience presented in chapter 3 and examples on past and present introduction of plant foods in the market given in chapter 4 , it is clear that on one side we have evidence that traditional plant food products might have adverse effects on human health but on the other side this problem seems to be manageable taking into account both the 
high number of traditional plant food products already on the market and the high number of novel plant food products already introduced. However both the high speed by which new foods can be introduced on the market today and the high expectations from the consumers about high quality of their food, has resulted in the political demand for regulation. High quality in this respect encompasses acceptable assurances about safety (including absence of allergenic potential), well established nutritional and health promotional properties of the novel plant food as part of the overall diet as well as qualified guidance on proper use of the novel plant food explaining preparation and cooking procedures and honouring its new taste and flavour. An argument for not being too restrictive in the regulation of exotic fruits and vegetables is the fact that in contrast to e.g. food additives these new products as long as they are in their original shape as fruits and vegetables usually are very visible for the consumers, so they on the basis of the available information can make an informed choice of their own.

A regulation with an approval procedure for plants for food use presents a lot of challenges:

- The present regulation is based on terms like "novel food", "history of safe use", "insufficient knowledge", "use in significant degree" etc. which in many cases are ill-defined and cause doubt about what should be approved and what should not.

- One basic problem with the sentence "regulation of novel food should be focusing on the food plants with insufficient knowledge to enable safe use" (formulation from the Australia/New Zealand guidelines) is that - although it makes sense from a scientific point of view - "insufficient knowledge" is not easily or not clearly defined. We may easily end up in a situation, where every food plant and its food products may need to be evaluated by the authorities for their safety. Therefore one of the first tasks is to clarify the extent of the evaluation and the approval procedure from a management point of view.

- It is normally recommended that the evaluation and approval take the botanical plant species as a starting point rather than the trivial trade name for the food such as kiwi or beans. However a plant species may contain many different varieties that need to be considered on their own.

- For many plant foods defined as novel in a region, the plant food is already common in another region, where it as an additional complication may be derived from different plant varieties due to years of traditional breeding like it is the case for the kiwi. In considering its history of use and or its history of safe use, the size of the "window" for the assessment needs to be defined taking into 
account which varieties of the plant species, if not all, are to be covered by the approval process. The distinction between food from highly bred varieties of a plant species and foods from the wild relatives might be essential in defining the novelty and carrying out the safety assessment.

- Traditional breeding, including the use of techniques such as crossing and chemically or physically induced mutation combined with selection pressure, performed after an approval may lead to considerable changes in the composition of the food from the plant. Here it is important to define the "window" for which the approval is valid. In cases where certain key components such as toxic substances or vitamins have been identified in the safety assessment process, the term for the approval could be that these key components in the food should not be outside certain defined limits. For other cases the window for approval might be broader and give room for traditional breeding without any specified limits. In this case the plant that is the source of the approved novel food can be regulated as any other traditional bred plant used for food in the future.

- History of safe use is an important criterion that may lead to approval of a food from a plant without further investigation. An attempt to define when history of safe use is fulfilled from a scientific view might easily end up with so high demands for scientific documentation that it is never readily obtainable even for well-known plant foods. Only few plant foods will have a history of safe use based on hard scientific evidence such as epidemiological surveillance. Premarket approval of novel plant foods may therefore need to apply a less scientific stringent procedure as the Canadian one (see page 11-12), where the case is qualified for assessment when history of use over several generations (i.e. 100 years) from other regions is evident and adverse effects, preparation for consumption, cultivation or harvesting, amounts likely to be consumed and normal composition are reported.

- Some of the novel foods are intended for marketing with arguments supposed to support their sale. In some cases these arguments are claims for keeping a good health and prevent chronic diseases, in other cases the claims intend to cure diseases. In the latter situation the borderline to medicine may be rather thin, and therefore the intension to market such a product as a novel food rather than a medicine should be carefully considered as part of the approval procedure.

Considering the nature of the issues raised above, the NNT early on concluded that most of these issues carry a strong management component with a number of societal values attached to them. These issues are addressed in the 2-step management procedure described in chapter 6 with 
determination of the novelty of the plant food as part of the establishment of a risk profile and with the establishment of a risk assessment policy for the conduct of the scientific risk assessment. The conclusions, which can be taken at each step, are highly depending on the scientific input into the process, including the scientific tools available for the safety evaluation presented in chapter 7 .

Most of these tools are also well known from other areas and widely discussed in connection with the safety assessment of food additives, pesticides, novel foods in general and foods from genetically modified plants. Therefore the discussion of those in chapter 7 and here does not go in every detail.

The new concepts and principles for risk assessment and risk management of novel plant foods introduced in this report are:

- The 2-step management procedure for establishing the novelty and for committing resources for safety assessment, and

- The use of a worldwide net of global, regional, local and ethnobotanical lists of food plants to guide the decision on novelty at the first step and to enable the safety assessment at the second step.

At the first step of the 2-step management procedure the management establishes a risk profile with the input from stakeholders, scientists in the field and consumer representatives taking into account the product itself, information on expected intake, history of use, values at risk, e.g. human health, economy, other potential consequences, consumer perception of risks and benefits, and societal distribution of risks and benefits. The plant lists discussed below are an integrated element of the history of use. The discussions at this step lead to the conclusion whether the plant food under consideration is traditional at the regional level or local level or a traditional ethnic food in the area, or actually a novel plant food, which needs a safety assessment according to the regulation.

At the second step of the 2-step management procedure the management decides on the general risk assessment policy for plant food defined as novel foods at the first step. Risk assessment policy in this context means that the authorities based upon scientific advice and based upon an overall societal value judgment of pros et cons define the extent and sequence of the scientific data which should form the basic mandatory demand for data to be made available for the scientific risk assessors in the premarket assessment phase. It is the authorities (= the management) who need to take the societal responsibility for the decision on availability of data for the assessment, since the resources to create the data cannot be committed by the scientists anyway, and since the scientific imagination of scientists for further request of scientific data is unlimited both due to their scientific wish to improve the assessment but also due to their pro- 
fessional desire to be able to take full scientific responsibility for the reliability of the safety assessment. In practice the resources for creating the basic scientific data may need to come from the applicant, but it depends on the formulation of the regulation in the different countries/regions. In the end the outcome of the risk assessments in terms of sensitivity, specificity, and the resulting predictability is totally dependent on the initially decided, managerial risk assessment policy.

For a smooth introduction of the so-called exotic fruits and vegetables from one region to another, the NNT recommends to use the "history of use"-concept as the core ingredient of the premarket submission. To the extent that the data submitted by the applicant can support the claim that a product has a history of safe use, the submission is accepted and no further data requested at this point. The NNT finds the Canadian approach quoted on page 11 excellent to guide the development of a general framework for both the global, regional and local risk assessment policies for novel plant foods.

To support and ease the availability of the standardised and high quality "history of use" data for the premarket submissions, the NNT recommends the development of a worldwide set of lists with recognised food plants covering the global, regional and local levels world-wide. The data given for each plant on the individual list should be identical to the data establishing the history of safe use of the fruits, roots or other plant tissues as human food in that region or geographical area, the list is covering. When a plant food from a plant already on one regional list is to be introduced as a novel plant food in another region, the data documenting its safe use in the first region can be used both for the submission by the applicant in the second region and by the authorities and their experts in that region. It is clear that the lists have to build on reliable, high quality information and exactly referenced sources in order to make it possible for the scientific assessors to perform a proper safety assessment.

Such lists do not exist at the present time, but each of the lists presented in Annex 2 and 3 give some hints regarding the wider perspectives of the concept suggested by the NNT. The list modified from FAO in Annex 2 represents plants that are commercialised and is based on production figures. This may cause some bias due to differences in use (e.g. as spices or for nutrition/energy), differences in the relation between production and actual intake. Not all countries can give exact information on the commercial production, and the production from plants grown in home gardens might be underestimated. However it is expected that the plants (or plants products) on the FAO list all have a history of safe use as food if used in ways and levels well established in the worldwide food intake.

Each regional list should contain (at best) those plant food items that are commonly used in that region and therefore in general have a long history of use and at least the potential for providing sufficient data to 
fulfil the criteria for having a history of safe use, data which in turn may facilitate the introduction of such plant foods to regions where they have not been eaten before. The modified NETTOX list in Annex 3 covering about 300 plants used as food sources in the EU area in 1997 is probably the best example of a regional/local plant list available at present. The NETTOX list with all its background data (not presented in details in this report) is the one coming closest to the type of list, which is in the mind of the NNT. In chapter 5 three examples of ethnobotanical surveys, which may be turned into ethnobotanical lists, are presented. They all contain candidates for types of plant foods indefinitely novel in EU.

Looking at the plant potential for introduction of novel plant foods, e.g. in Europe, there are over 1100 edible fruits recognized for food use in South America, 782 species of edible plants in Peru alone, and up to 7000 other plant species used in the human food supply around in the world as explained in chapter 5 . The 101 plant species on the NUS list in Annex 1 gives also some hints in that direction, although many of the plants are not to be considered novel (48 of the plants are on the NETTOX list). It is stated on the web site of IPGRI that the intention of the NUS list is to draw attention to plants with a potential to securing food and income in some poor, rural communities. However, it can be expected that many of these potential novel food plants in some regions with few starvation problems will fall into the category of plant foods being sold based on their claims for health promoting capabilities. Such plant food products may trigger considerations that the scientific bases for such a marketing procedure should be documented in order to assure against negative effects of over-use. Requirement for an appropriate labelling could in some cases be needed to solve some of the adverse health issues that the introduction of such plant foods might raise.

The paradigm for the safety assessment of novel plant foods and novel plant food ingredients with all types of data sources is presented in Figure 2 at page 34. Based upon the discussion in this chapter it is clear that in the opinion of the NNT the well described history of use possibly picked directly from one of the food plant lists will be sufficient to establish history of safe use in another region. Therefore new studies (chemical studies, animal studies, human studies, exposure studies) beyond those already cited in the history of use may not be needed in the premarket situation for the exotic fruits and vegetables. Of course such studies will be needed, if the cited history of use cannot lead to the establishment of history of safe use due to shortcomings in the characterization of the plant species, in the compositional data and historical evidence of food use, due to the nature and severity of possible adverse effects and the character of physiological effects, due to insecure safety consequences of the cultivation, harvesting, processing and preparation methods, and/or due to the information regarding possible amounts of the novel plant food to be eaten. A similar situation with a need for basic chemical studies, animal 
studies, human studies and exposure studies exists if the novel plant food is derived from a not traditionally eaten part a traditional food plant, or if the novel plant food is derived from a plant, which never has been the source of human food anywhere.

This report and the recommendations of this report only address the novelty and safety of human foods derived from plants. It is to be foreseen that similar considerations and approximately similar recommendations could - or should - be developed to address the novelty and safety of mushrooms where only few species out of several thousands in each region are edible for humans.

This report on exotic fruits and vegetables as novel and safe sources for food gives "the-state-of-the-art" in an area of the food safety arena, where there is still very little experience.

Each definitive conclusion regarding novelty and safety of these plant foods needs to be taken with caution, since all perspectives need to be taken into account and no one forgotten, because these conclusions in the end have great consequences for the global food supply and the global trade with food commodities and may change the perspectives for the physical and cultural survival of large and small communities.

Therefore the heading of this chapter announces a plea for a continued interactive exchange of concepts and ideas between management and science in this field - both at the local, regional and global levels and between those levels. 



\section{Overall conclusions and recommendations.}

The European Union, Australia/New Zealand and Canada have introduced a pre-market notification or assessment and approval of novel foods in their regulation, and the managerial and scientific instruments for the enforcement of this regulation are under development.

A special area in this respect is the area of plant foods, where mutually accepted concepts and principles for risk assessment and risk management of novel plant foods are urgently needed to ensure a sufficient global production of safe and nutritious food and a smooth international trade based on mutual acceptance of this food.

This report of the NNT analyses this regulatory situation and identifies the definitions of novelty and safety in relation to plant foods as the main challenges both globally, regionally and locally. The outcome of this analysis is that the NNT recommends the introduction of:

- A 2-step management procedure, first to establish the novelty and secondly to define and commit resources for the safety assessment, and

- A worldwide net of global, regional, local and ethnobotanical lists of food plants to guide the decision on novelty at the first step and to enable the safety assessment at the second step.

At the first step of the 2-step management procedure the management establishes a risk profile for the plant food with the input from stakeholders, scientists in the field and consumer representatives taking into account the product itself, information on expected intake, history of use, values at risk, e.g. human health, economy, other potential consequences, consumer perception of risks and benefits, and societal distribution of risks and benefits. The plant lists discussed below are an integrated element of the history of use. The discussions at this step should lead to the conclusion whether the plant food under consideration is traditional at the regional level, local level or a traditional ethnic food in the area, or actually a novel plant food, which needs a safety assessment according to the regulation.

At the second step of the 2-step management procedure recommended above the management decides on the general risk assessment policy for all plant foods defined as novel foods at the first step. Risk assessment policy in this context means that the authorities, based upon scientific advice and based upon an overall societal value judgment of pros et cons, 
define the extent and sequence of the scientific data which should as a basic mandatory demand be made available for the scientific risk assessors in the premarket assessment phase. In the end, the outcome of the risk assessments in terms of sensitivity, specificity, and the resulting predictability is totally dependent on the initially decided, managerial risk assessment policy.

For a smooth introduction of the so-called exotic fruits and vegetables from one region to another the NNT recommends to use the "history of use"-concept as the core ingredient of the premarket submission. To the extent that the data submitted by the applicant can support the claim that a product has a history of safe use, the submission is accepted and no further data requested at this point. The NNT finds the Canadian approach quoted on page 11 excellent to guide the development of a general framework for both the global, regional and local risk assessment policies for novel plant foods.

To support and ease the availability of the standardised and high quality "history of use" data for the premarket submissions the NNT recommends the development of a set of lists with food plants recognized either at the global level, at different regional levels or local levels or known as ethnobotanical food plants in different places. The individual lists should reflect the use of plant foods in the region, at the local level or the ethnobotanical setting, where they are developed. When all of them are available, they should create a complete global picture of the use of plant foods. The NNT expects that the combined use of data from all these lists will facilitate the mutual acceptance of safety and benefits of plant foods and plant food ingredients across political, economical and cultural borders. It is clear that the lists need to build on reliable, high quality information and proper reference sources in order to meet the acceptance of critical scientific assessors. The NNT concludes on this basis that the well described history of use picked directly from a well developed food plant lists in one region will be sufficient to establish history of safe use in another region. Therefore new studies like chemical studies, animal studies, human studies and exposure studies beyond those already cited in the history of use may be unnecessary in the premarket situation for the exotic fruits and vegetables. Of course such studies will be needed, if the cited history of use cannot lead to the establishment of history of safe use, if the novel plant food is derived from a not traditionally eaten part of a traditional food plant, or if the novel plant food is derived from a plant, which never has been the source of human food any place.

This report describes "the-state-of-the-art" and gives recommendations in an area of the food safety arena, where only few concepts and ideas are fixed yet by administrative practices and scientific "rules-ofthumb". Each definitive conclusion needs to be taken with caution, since all potential consequences need to be taken into account and no one forgotten, because these conclusions in the end have great perspectives for 
the global food supply and the global trade with food commodities and may change the basis for the physical and cultural survival of large and small communities.

Therefore the NNT strongly recommends continued interactive exchanges of concepts and ideas between management and science in this field both at the local, regional and global levels and between those levels. 



\section{References.}

ACNFP annual report (1999): Ministry of Agriculture, Fisheries and Food and Department of Health.

ACNFP annual report (1996): Appendix IX. ACNFP report on seeds from the narrow leaved lupine (Lupinus angustifolius), pp. 14-15, 107-123. Ministry of Agriculture, Fisheries and Food and Department of Health.

ACNFP annual report 2003 (2004): Food Standards Agency, London, U.K. URL: http://www.food.gov.uk/multimedia/pdfs /acnfp2003.pdf

Allen JG (1998): Toxins and lupinosis. In: Lupin as Crop Plants. Biology, Production and Utilization. JS Gladstones, CA Atkins and J Hamblin (eds.) pp. 411435, CAB International.

Andersson C (1999): Glycoalkaloids in tomatoes, eggplants, pepper and two Solanum species growing wild in the Nordic countries. TemaNord 1999:599

Bast A, Chandler RF, Choy PC, Delmulle LM, Gruenwald J, Halkes SBA, Keller K, Koeman JH, Peters P, Przyrembel H, de Ree EM, Renwick AG, Vermeer ITM (2002): Botanical health products, positioning and requirements for effective and safe use. Environ. Toxicol. Pharmacol. 12:195-211.

Beier RC (1990): Natural pesticides and bioactive components in foods. Rev. Environ. Contam. Toxicol. 113:47-137.

Boulter GS (1983): The History and Marketing of Rapeseed Oil in Canada. In: High and Low Erucic Acid Rapeseed Oils. Production, Usage, Chemistry, and Toxicological Evaluation. JKG Kramer, FD Sauer and WJ Pidgen. (Eds). Academic Press.

Brack Egg A (1999): Diccinario enciclopédico de plantas útiles del Perú. PNUD/CBC, Lima, Peru.

Bublin M, Mari A, Ebner C, Knulst A, Scheiner O, Hoffmann-Sommergruber K, Breiteneder H, Radauer C (2004): IgE sensitization profiles toward green and gold kiwifruits differ among patients allergic to kiwifruit from 3 European countries. J. Allergy Clin. Immunol. 114:1169-1175

Cellini F, Chesson A, Colquhoun I, Constable A, Davies HV, Engel KH, Gatehouse AMR, Kärenlampi S, Kok EJ, Leguay J-J, Lehesranta S, Noteborn HPJM, Pedersen J and Smith M (2004): Unintended effects and their detection in genetically modified crops. Food Chem. Toxicol. 42:1089-1125.

CFSAN (1992): Phytohaemagglutinin. In: Foodborne Pathogenic Microorganisms and Natural Toxins Handbook (Bad Bug Book); Center for Food Safety \& Applied Nutrition, U.S. Food \& Drug Administration. URL:

http://www.cfsan.fda.gov/ mow/chap43. html

Chang J-M, Hwang S-J, Kuo H-T, Tsai JC, Guh J-Y, Chen H-C, Tsai J-H, Lai Y$\mathrm{H}$ (2000): Fatal outcome after ingestion of star fruit (Averrhoa carambola) in uremic patients. Am. J. Kidney Dis. 35:189-193.

Chang C-T, Chen Y-C, Fang J-T, Jiamg CC (2002): Star fruit (Averrhoa carambola) intoxication: an important cause of consciousness disturbance in patients with renal failure. Renal Failure 24:379382.

Chen C-L, Fang H-C, Chou K-J, Wang JS, Chung H-M (2001): Acute oxalate nephrophathy after ingestion of star fruit. Am. J. Kidney Dis. 37:418-422.

Chen C-L, Chou K-J, Wang J-S, Yeh J-H, Fang H-C, Chung H-M (2002): Neurotoxic effects of carambola in rats: the role of oxalate. J. Formos. Med. Assoc. 101:337-341.

Codex Alimentarius (2004): Foods derived from biotechnology. FAO/WHO, Rome

Coppens D’Eeckenbrugge G, Ferla DL (2000): Fruits from America. An Ethnobotanical inventory.

IPGRI (International Plant Genetic Resources Institute). URL: http://www.ciat.cgiar.org/ipgri/fruits_fro m_americas/frutales/fruits_from_americ a.htm

Dybing E, Doe J, Groten J, Kleiner J, O’Brien J, Renwick AG, Schlatter J, Ste- 
inberg P, Tritscher A, Walker R, Younes M (2002): Hazard characterisation of chemicals in food and diet: dose response, mechanisms and extrapolation issues. Food Chem. Toxicol. 40:237-282.

Eisenbrand G, Pool-Zobel B, Baker V, Balls M, Blaauboer BJ, Boobis A, Carere A, Kevekordes S, Lhuguenot J-C, Pieters R, Kleiner J (2002): Methods of in vitro toxicology. Food Chem. Toxicol. 40:193-236

English RM, Aalbersberg W, Scheelings P (1996): Pacific Island Foods. Institute of Applied Sciences Techn. Rep. 96/02, University of the South Pacific, Suva, Fiji.

European Commission (1997): Commission recommendation of 29 July 1997 concerning the scientific aspects and the presentation of information necessary to support applications for the placing on the market of novel foods and novel food ingredients and the preparation of initial assessment reports under Regulation (EC) No 258/97 of the European Parliament and of the Council. Official Journal L 253:0001-0036.

Fabech B, Bryhni K, Forshell LP, Georgsson F, Gry J, Hansen BT, Hallström H, Hatakka M, Holene E, Kapperud G, Kristinsson J, Maijala R, Nielsen NL, Nordström U, Schultz AC, Solheim C, Thorkelsson ÁE (2002): A Practical Approach to the Application of the Risk Analysis Process. Illustrated with two examples caffeine and campylobacter. TemaNord 2002:510.

Fang H-C, Chen C-L, Wang J-S, Chou KJ, Chiou Y-S, Lee P-T, Yeh J-H, Yeh MY, Chung H-M (2001): Acute oxalate nephropathy induced by star fruit in rats. Am. J. Kidney Dis. 38:876-880.

FAO (1996): Report on the State of the World's Plant Genetic Resources for Food and Agriculture, prepared for the International Technical Conference on Plant Genetic Resources, Leipzig, Germany, 17-23 June 1996. Food and Agriculture Organisation of the United Nations, Rome.

FAOSTAT (2004): Agricultural Data. URL:

http://faostat.fao.org/faostat/collections? subset=agriculture

FAO/WHO (1995): Application of Risk Analysis to Food Standard Issues. Report of the Joint FAO/WHO Expert Con- sultation. Geneva, Switzerland, 13-17

March 1995. WHO, Geneva.

FAO/WHO (1997): Risk Management and

Food Safety. Report of a Joint

FAO/WHO Consultation. Rome, Italy, 27-31 January 1997. FAO, Rome.

FAO/WHO (2000): Safety aspects of genetically modified foods of plant origin. Report of a joint FAO/WHO Expert Consultation on Foods Derived from Biotechnology. Geneva, Switzerland, 29 May - 2 June 2000. World Health Organization, Geneva.

FAO/WHO (2001): Evaluation of Allergenicity of Genetically Modified Foods. Report of a Joint FAO/WHO Expert Consultation on Allergenicity of Foods Derived from Biotechnology, 22-25 January 2001. Food and Agriculture Organisation of the United Nations, Rome.

Ferguson AR (1999): New Temperate Fruits: Actinidia chinensis and Actinidia deliciosa. In: Perspectives on new crops and new uses. J. Janick (ed.), pp. 342347. ASHS Press: Alexandria, VA.

Frémont S, Moneret-Vautrin DA, Nicolas JP (2001): Allergenicity of the nan-gai nut. Allergy 56:581.

FSANZ (2003): Erucic Acid in Food: A Toxicological Review and Risk Assessment. Technical Report Series. No. 21. Food Standards Australia New Zealand; Canbarra. URL:

http://www.foodstandards.gov.au/mediar eleasespublications/publications/

FSANZ (2004a): Australia New Zealand Food Standards Code, standard 1.5.1 Novel Foods

Including Amendment 70 (FSC 12), 29 April 2004. URL: http://www.foodstandards.gov.au/foodst andardscode/

FSANZ (2004b): General information to assist in applying to amend the Australian New Zealand Food Standards Code - Novel foods Updated April 2004, URL:

http://www.foodstandards.gov.au/_srcfil es/Novel_Food_Guidelines_June_2004.p df

Gepts P (2002): A comparison between crop domestication, classical plant breeding and genetic engineering. Crop Sci. 42:1780-1790

Getahun H, Lambein F, Vanhoorne M, Van der Stuyft P (2003): Food-aid cereals to reduce neurolathyrism related to 
grass-pea preparations during famine. Lancet 362:1808-10.

Getahun H, Lambein F, Vanhoorne M, Van der Stuyft P (2005): Neurolathyrism risk depends on type of grass pea preparation and mixing with cereals and antioxidants. Trop. Med. Int. Health 10:169178.

Health Canada (1994): Guidelines for the safety assessment of Novel Foods, September 1994. URL:

http://www.hc-sc.gc.ca/fnan/alt_formats/hpfbdgpsa/pdf/legislation/novele_e.pdf

Health Canada (1999): Regulations Amending The Food and Drugs Regulations (948 - Novel Foods) - October 27, 1999. URL: http://www.hc-sc.gc.ca/fnan/alt_formats/hpfb-dgpsa/pdf/gmfagm/schedule-annexe948_e.pdf

Hegarty MP, Hegarty EE, Wills RBH (2001): Food safety of Australian plant bushfoods. Rural Industries Research and Development Corporation, New Plant Products Research and Development, Queensland, Australia.

Hermann M (2004): The amendment of the EU Novel Food Regulation: opportunity for recognizing the special status of exotic traditional foods; Discussion paper, June 2004, International Plant Genetic Resources Institute (IPGRI).

Howlett J, Edwards DG, Cockburn A, Hepburn P, Kleiner J, Knorr D, Kozianowski G, Müller D, Peijnenburg A, Perrin I, Poulsen M, Walker R (2003): The safety assessment of Novel Foods and concepts to determine their safety in use. Int. J. Food Sci. Nutr. 54Supp1:S1-32.

ILSI (International Life Sciences Institute) Europe (2003): Application and use of the term "History of Safe Use" in the safety assessment of novel foods, and foods and feeds derived from GM crops. Novel Food Task Force group and invited experts meeting October 2003.

IPGRI (International Plant Genetic Resources Institute) (2004): Conserving and increasing the Use of Neglected and Underutilized Crop Species. Examples of NUS in the Regions. URL:

http://www.ipgri.cgiar.org/nus/home.htm Janick J (1999): New crops and the search for new food resources. In: Perspectives on new crops and new uses. J. Janick (ed), pp. 104-110. ASHS Press, Alexandria, VA.
Johanns ES, van der Kolk LE, van Gemert HM, Sijben AE, Peters PW, de Vries I (2002): Én epidemie van epileptische annvallen na drinken van kruidenthee. Ned. Tijdschr. Geneeskd. 146:813-816.

Kimber I, Dearman RJ (2002): Approaches to assessment of the allergenic potential of novel proteins in food from genetically modified crops. Toxicol. Sci. 68:4-8.

Knudsen I, Poulsen M (2005): Testing of Genetically Modified Foods for safety and nutritional adequacy in the 90-Day Rat Feeding Study: Overall Strengths and Weaknesses, Possibilities and Limitations Discussed on the Basis of the Experiences gained from the SAFOTEST Approach. (Submitted to Food Chem. Toxicol.)

Kunkel G (1984): Plants for human consumption an annotated checklist of the edible phanerogams and ferns. Koeltz Scientific Books, Königstein, Germany.

König A, Cockburn A, Crevel RWR, Debruyne E, Grafstroem R, Hammerling U, Kimber I, Knudsen I, Kuiper HA, Peijnenburg AACM, Penninks AH, Poulsen M, Schauzu M, Wal JM (2004): Assessment of the safety of food derived from genetically modified (GM) crops. Food Chem. Toxicol. 42:1047-1088.

Levnedsmiddelstyrelsen (1990): Bønner skal tilberedes rigtigt - ellers kan de være skadelige. Søborg, Denmark

Lucas JSA, Lewis SA, Hourihane JOB (2003): Kiwi fruit allergy: A review. Pediatr. Allergy Immunol. 14:420-428.

Lucas JSA, Grimshaw KEC, Collins K, Warner JO, Hourihane JO’B (2004): Kiwi fruit is a significant allergen and is associated with differing patterns of reactivity in children and adults. Clin. Exp. Allergy 34:1115-1121.

Martin LC, Caramori JST, Barreti P, Soares A (1993): Intractable hiccups induced by carambola (Averrhoa carambola) ingestion in patients with end-stage renal failure. J. Bras. Nefrol. 15:92-94.

McClean P, Kami J, Gepts P 2004: Genomics and Genetic Diversity in Common Bean. In: Legume Crop Genomics (Wilson RF, Stalker HT and Brummer EC (eds.)) pp. 60-82. AOCS Press; Champaign, Illiois

Millonig G, Staldmann S, Vogel W (2005): Herbal hepatotoxicity: acute hepatitis caused by a Noni preparation 
(Morinda citrifolia). Eur. J.

Gastroenterol. Hepatol. 17:445-447.

Morisset $\mathrm{M}$, Boulègue $\mathrm{M}$, Beaudouin $\mathrm{E}$, Pirson F, Rancé F, Gallen C, MoneretVautrin D-A (2003): Anaphylaxie alimentaire sévère et léthale cas rapportés en 2002 par le réseau d'allergovigilance. Rev. Fr. Allergol. Immunol. Clin. 43:480-485.

Morris SC, Lee TH (1984): The toxicity and teratogenicity of Solanaceae glycoalkaloids, particularly those of the potato (Solanum tuberosum): a review. Food Tech. Australia 36:118-124.

Morton JF (1987): Oxalidaceae. In: Fruits of Warm Climates, pp. 125-128, Flair Books; Miami, FL.

Moyses Neto M, Robl F, Coutinho Netto J (1998): Intoxication by star fruit (Averrhoa carambola) in six dialysis patients? (Preliminary report) Nephrol. Dial. Transplant. 13:570-572.

Moyses Neto J, Cardeal da Costa JA, Garcia-Cairasco N, Coutinho Netto J, Nakagawa B, Dantas M (2003): Intoxication by star fruit (Averrhoa carambola) in 32 uraemic patients: treatment and outcome. Nephrol. Dial. Transplant. 18:120-125.

Myers N (1983): A wealth of wild species: storehouse for human welfare. Westview Press; Boulder, Colo.

NETTOX (1997): Nettox List of Food Plants. Information on inherent food plant toxicants, report 2. Danish Vet. Food Adm; Søborg, Denmark

OECD (2002): Consensus Document on Compositional Considerations for New Varieties of Maize (Zea Mays): Key Food and Feed Nutrients, Anti-nutrients and Secondary Plant Metabolites. Series on the Safety of Novel Foods and Feeds, No. 6. Organisation for Economic Cooperation and Development, Paris. URL: http://www.olis.oecd.org/olis/2002doc.n sf/LinkTo/env-jm-mono(2002)25

Panciera RJ, Martin T, Burrows GE, Taylor DS, Rice LE (1990): Acute oxalate poisoning attributable to ingestion of curly dock (Rumex crispus) in sheep. J. Am. Vet. Med. Assoc. 196:1981-1984. Panter KE, Keeler RF (1993): Quinolizidine and piperidine alkaloid teratogens from poisonous plants and their mechanism of action in animals. Vet. Clin. North Am. Food Anim. Pract. 9:33-40.
Petterson DS, Ellis ZL, Harris DJ, Spadek ZE (1987): Acute toxicity of the major alkaloids of cultivated Lupinus angustifolius seed to rats. J. Appl. Toxicol. 7:51-53.

Radcliffe M (2005): Lupin flour anaphylaxis. Lancet 365:1360.

Rao SLN (2001): Do we need more research on neurolathyrism? Lathyrus Lathyrism Newsletter 2: 2-4

Robbins MC, Petterson DS, Brantom PG (1996): A 90-day feeding study of the alkaloids of Lupinus angustifolius in the rat. Food Chem. Toxicol. 34:679-686.

Sampson HA, Burks AW (1996): Mechanisms of food allergy. Annu. Rev. Nutr. 16:161-177.

Sanz P, Reig R (1992): Clinical and pathological findings in fatal plant oxalosis: A review. Am. J. Forensic Med. Pathol. 13:342-345.

SCF (2000): Opinion on the safety assessment of the nuts of the Ngali tree. SCF/CS/NF/DOS/5 ADD 1 REV 3 final. 14/03/00. URL:

http://europa.eu.int/comm/food/fs/sc/scf/ out54_en.pdf

SCF (2002): Opinion of the Scientific Committee on Food on Tahitian Noni juice. SCF/CS/NF/DOS/18 ADD 2 Final. 11/12/2002. URL: http://europa.eu.int/comm/food/fs/sc/scf/ out151_en.pdf.

Schilter B, Andersson C, Anton R, Constable A, Kleiner J, O'Brien J, Renwick AG, Korver O, Smit F, Walker R (2003): Guidance for the safety assessment of botanicals and botanical preparations for use in food and food supplements. Food Chem Toxicol. 41:1625-49.

Schmidlin-Meszaros J (1973): Eine Nahrungsmittelvergiftung mit Lupinenbohnen. Mitt. Geb. Lebensm. Hyg. 64:195205.

Siddique K, Hanbury C 2005: „Ceora“: Australia's first grasspea variety. CLIMA (Centre for Legumes in Mediterranean Agriculture) newsletter, April 2005

Slanina P (1990): Assessment of healthrisks related to glycoalkaloids („Solanine“) in potatoes: A Nordic view. Report from the Nordic Working Group on Food Toxicology and Risk Assessment. Vår Föda 43Supp1:1-15.

Spencer PS, Ludolph A, Dwivedi MP, Roy D, Hugon J, Schaumburg HH (1986): Lathyrism: evidence for role of the neu- 
roexcitatory aminoacid BOAA. Lancet 328:1066-1067.

SSC (2000): First Report of the Scientific Steering Committee on the Harmonisation of Risk Assessment Procedures. European Commission, Health \&Consumer Protection DirectorateGeneral. URL:

http://europa.eu.int/comm/food/fs/sc/ssc/ out83_en.pdf

Appendices:

http://europa.eu.int/comm/food/fs/sc/ssc/ out84_en.pdf

SSC (2003a): Second Report of the Scientific Steering Committee on the Harmonisation of Risk Assessment Procedures. European Commission, Health \&Consumer Protection DirectorateGeneral. URL:

http://europa.eu.int/comm/food/fs/sc/ssc/ out361_en.pdf

SSC (2003b): Final Report on Setting the Scientific Frame for the Inclusion of New Quality of Life Concerns in the Risk Assessment Process. Adopted 1011 April 2003. URL:

http://europa.eu.int/comm/food/fs/sc/ssc/ out357_en.pdf

Stadlbauer V, Fickert P, Lackner C, Schmerlaib J, Krisper P, Trauner M, Stauber RE (2005): Hepatotoxicity of NONI juice: Report of two cases. World J. Gastroenterol. 11:4758-60

Sten E, Stahl Skov P, Andersen SB, Torp AM, Olesen A, Bindslev-Jensen U, Poulsen LK, Bindslev-Jensen CA (2002): Allergenic components of a novel food, Micronesian nut Nangai (Canarium indicum), shows IgE crossreactivity in pollen allergic patients. Allergy 57:398-404.

Tap N, Bich NK (2003): Morinda citrifolia L. In: Plant Resources of South-East Asia No. 12(3): Medicinal and poisonous plants. RHMJ Lemmens, N Bunyapraphatsara (eds.), pp 304-305, Backhuys Publisher; Leiden, The Netherlands.
Thomson LAJ, Evans B 2004: Canarium indicum var. Indicum and C. harveyi (Canarium nut) In: Species Profiles for Pacific Island Agroforestry. CR Elevitch (ed.) Permanent Agriculture Resources (PAR), Holualoa, Hawaii. URL: http://www.traditionaltree.org.

Tse K-C, Yip P-S, Lam M-F, Choy B-Y, Li F-K, Lui S-L, Lo W-K, Chan T-M, Lai K-N (2003): Star fruit intoxication in uraemic patients: case series and review of the literature. Intern. Med. J. 33:314316.

Weiss E, Wetterstrom W, Nadel D, BarYosef O (2004): The broad spectrum revisited: Evidence from plant remains. Proc. Natl. Acad. Sci. USA 101:95519555

WHO (1987): Principles for the safety assessment of food additives and contaminants in food. No.70. WHO, Geneva.

WHO (1999): Principles for assessment of risk to human health from exposure to chemicals. No.210. WHO, Geneva. WHO (2003): GEMS/FOOD Regional Diets - Regional per capita Consumption of raw and Semi-processed Agricultural Commodities. URL:

http://www.who.int/foodsafety/chem/ge ms_regional_diet.pdf

Wilson EO (1992): The Diversity of Life. Penguin; London.

Wink M, Meissner C, Witte L (1995): Patterns of quinolizidine alkaloids in 56 species of the genus Lupinus. Phytochemistry 38:139-153.

Yang SH, Wang HL, Wang WC (1995): Studies on the changes of organic acid and sugar content of carambola during pickling process. J. Agr. Res. China 44:135-146.

Zohary D, Hopf M (2000): Domestication of Plants in the Old World: The origin and spread of cultivated plants in West Asia, Europe and the Nile Valley ( $3^{\text {rd }}$ ed.) Oxford University Press; New York 


\section{Annex 1. Examples of NUS in the Regions}

From http://www.ipgri.cgiar.org/nus/home.htm . The column "Americas" contains no marks but instead the page contain a link to a inventory list of native fruits from America (http://www.ciat.cgiar.org/ipgri/fruits_from_ americas/frutales/fruits_from_america.htm ).

\begin{tabular}{|c|c|c|c|c|c|c|}
\hline Botanical name & Common name & Europe & \begin{tabular}{|l} 
Asia \\
Pacific \\
Oceania
\end{tabular} & $\begin{array}{l}\text { Central } \\
\text { West } \\
\text { Asia } \\
\text { North } \\
\text { Africa }\end{array}$ & $\begin{array}{l}\text { Sub } \\
\text { Saharan } \\
\text { Africa }\end{array}$ & Americas \\
\hline \multicolumn{7}{|l|}{ Cereals and pseudocereals } \\
\hline Brachiaria deflexa & guinea millet & & & & $x$ & \\
\hline Digitaria exilis & fonio & & & & $x$ & \\
\hline Eleusine coracana & finger millet & & $x$ & & & \\
\hline Fagopyrum spp. & buckwheat & $x$ & $x$ & & & \\
\hline Pennisetum glaucum & pennisetum & & & & $x$ & \\
\hline Secale cereale & rye & $x$ & & $x$ & & \\
\hline Setaria italica & foxtail millet & & $x$ & & & \\
\hline Stipa lagascae & stipa & & & $x$ & & \\
\hline Triticum monococcum/ dic./ spelt & hulled wheat & $x$ & & $x$ & & \\
\hline \multicolumn{7}{|l|}{ Legumes } \\
\hline Kerstingiella geocarpa & Kersting's groundnut & & & & $x$ & \\
\hline Lathyrus spp. & grass pea & & $x$ & & & \\
\hline Lupinus spp. & lupin & $x$ & & $x$ & & \\
\hline Macrotyloma uniflorum & horse gram & & $x$ & & & \\
\hline Mucuna spp. & velvet bean & & & & $x$ & \\
\hline Phaseolus angularis & adzuki bean & & $x$ & & & \\
\hline Phsophocarpus tetragonolobus & winged bean & & $x$ & & & \\
\hline Plectranthus esculentus & coffee potato & & & & $x$ & \\
\hline Sphenostylis stenocarpa & African yam bean & & & & $x$ & \\
\hline Trigonella foenum graecum & fenum-greek & & & $x$ & & \\
\hline Tylosema esculentum & marama bean & & & & $x$ & \\
\hline Vigna subterranea & bambarra groundnut & & & & $x$ & \\
\hline \multicolumn{7}{|l|}{ Vegetables } \\
\hline Abelmoshus esculentum & okra & & $x$ & & & \\
\hline Allium spp. & $\begin{array}{l}\text { shallot, chives, leek, } \\
\text { onion, garlic }\end{array}$ & $x$ & & & & \\
\hline Amaranthus spp. & amaranth & & & & $x$ & \\
\hline Brassica spp. & brassicas & $x$ & & $x$ & & \\
\hline Capparis spp. & caper & $x$ & & $x$ & & \\
\hline Chicorium spp. & chicory & $x$ & & $x$ & & \\
\hline Chorchorus olitorius & chorchorus & & & & $x$ & \\
\hline
\end{tabular}




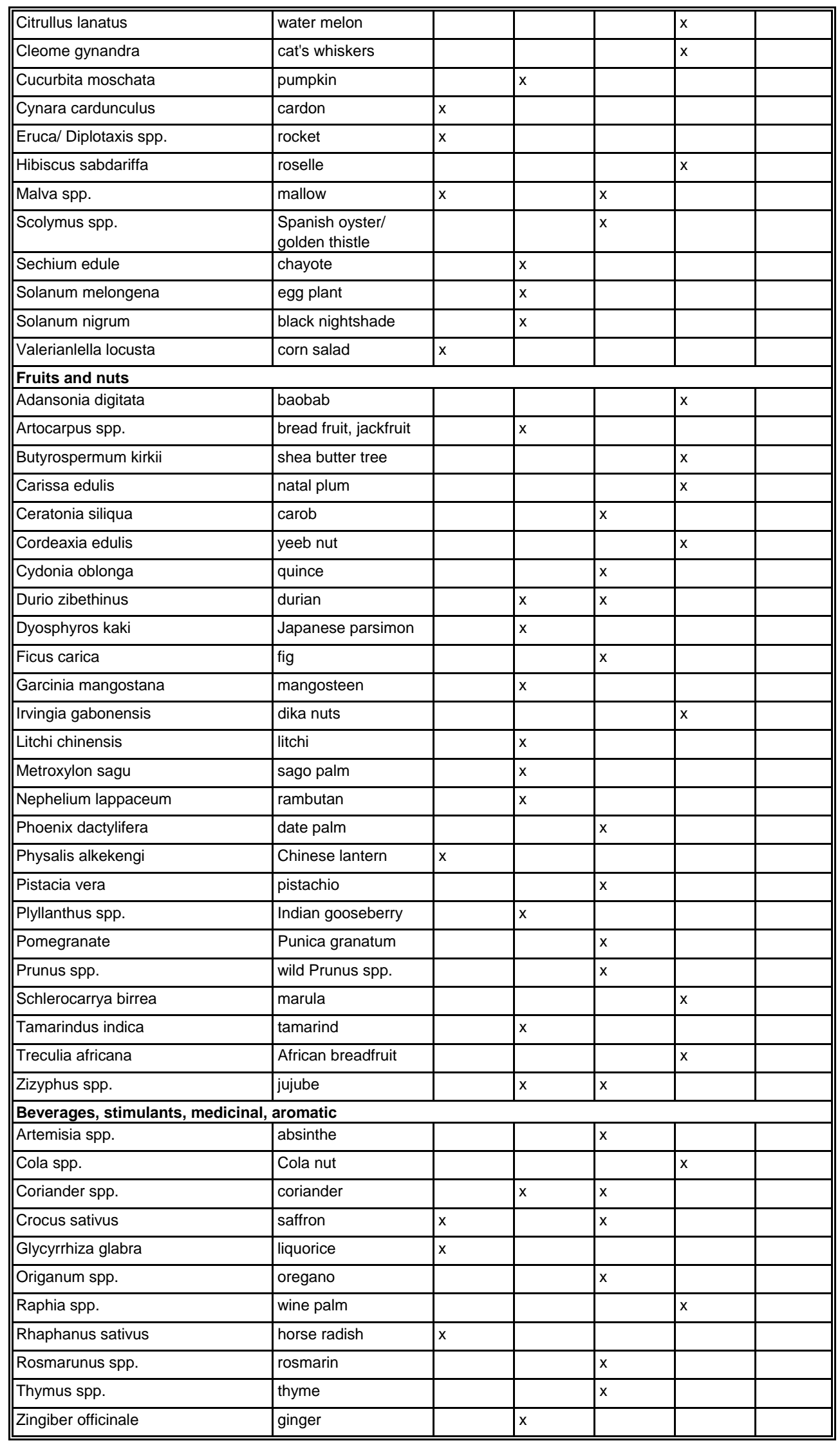




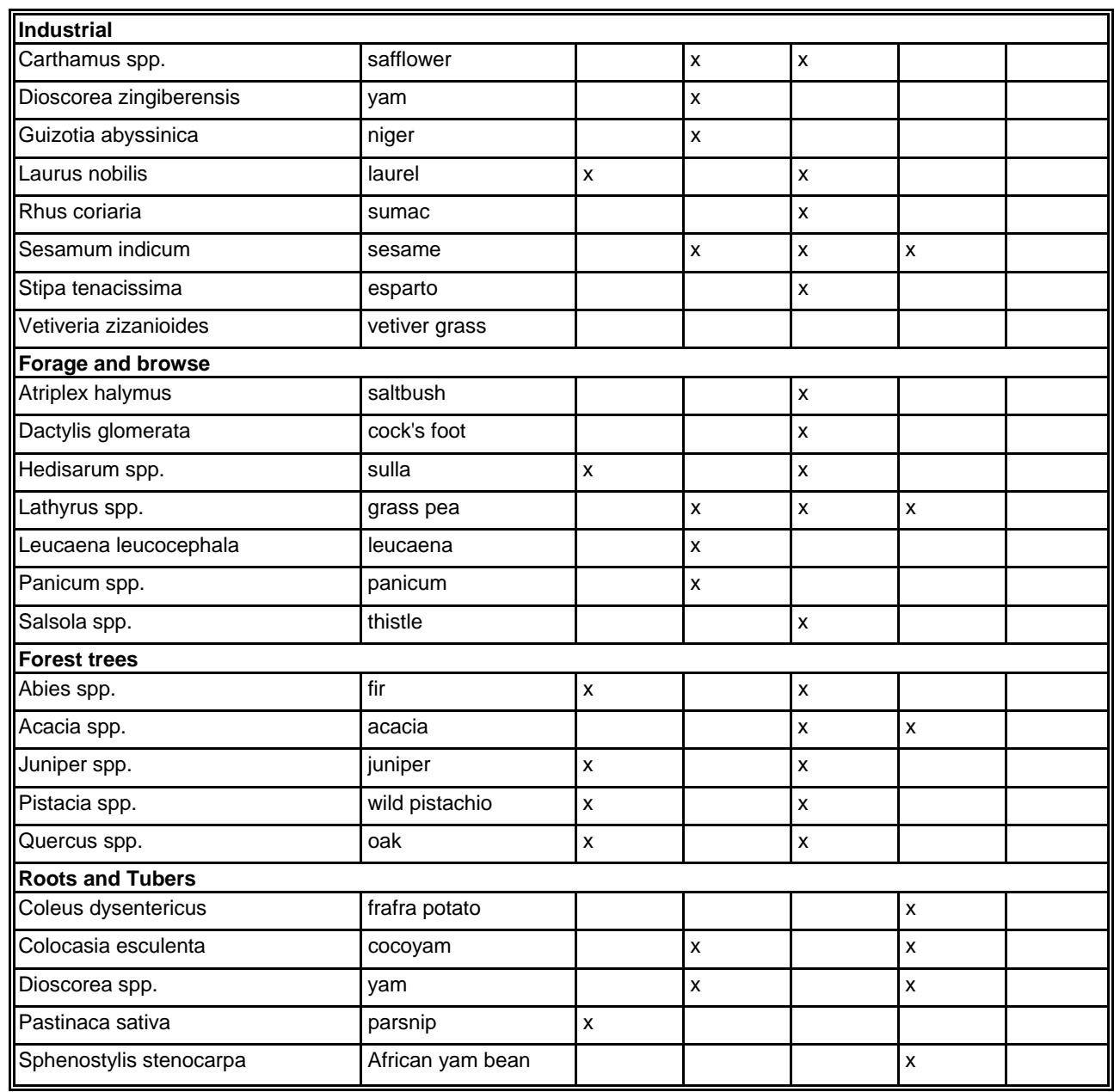




\section{Annex 2. Draft global list based on the FAO-list of global plant food production}

Developed on the basis of: http://faostat.fao.org/faostat/collections?subset=agriculture

\begin{tabular}{|c|c|c|}
\hline & Item & Megaton \\
\hline 1 & Sugar Cane & 1.333 .253 \\
\hline 2 & Maize & 638.043 \\
\hline 3 & Rice, Paddy & 589.126 \\
\hline 4 & Wheat & 556.349 \\
\hline 5 & Potatoes & 310.810 \\
\hline 6 & Sugar Beets & 233.487 \\
\hline 7 & Soybeans & 189.234 \\
\hline 8 & Cassava & 189.100 \\
\hline 9 & Barley & 141.503 \\
\hline 10 & Sweet Potatoes & 121.853 \\
\hline 11 & Tomatoes & 113.308 \\
\hline 12 & Watermelons & 91.790 \\
\hline 13 & Bananas & 69.286 \\
\hline 14 & Cabbages & 65.956 \\
\hline 15 & Grapes & 60.883 \\
\hline 16 & Sorghum & 59.584 \\
\hline 17 & Apples & 57.967 \\
\hline 18 & Seed Cotton & 56.097 \\
\hline 19 & Coconuts & 52.940 \\
\hline 20 & Onions, Dry & 52.547 \\
\hline 21 & Yams & 39.913 \\
\hline 22 & Cucumbers and Gherkins & 39.599 \\
\hline 23 & Rapeseed & 36.146 \\
\hline 24 & Groundnuts in Shell & 35.658 \\
\hline 25 & Plantains & 32.974 \\
\hline 26 & Millet & 29.806 \\
\hline 27 & Eggplants & 28.994 \\
\hline 28 & Sunflower Seed & 27.740 \\
\hline 29 & $\begin{array}{l}\text { Cantaloupes \& other } \\
\text { Melons }\end{array}$ & 26.749 \\
\hline 30 & Oats & 26.269 \\
\hline 31 & Mangoes & 25.563 \\
\hline 32 & Carrots & 23.321 \\
\hline 33 & $\begin{array}{l}\text { Chillies \& Peppers, } \\
\text { Green }\end{array}$ & 23.248 \\
\hline
\end{tabular}

\begin{tabular}{|c|c|c|}
\hline 34 & $\begin{array}{l}\text { Tang. Mand. Clement. } \\
\text { Satsuma }\end{array}$ & 20.950 \\
\hline 35 & Lettuce & 20.810 \\
\hline 36 & Beans, Dry & 19.038 \\
\hline 37 & Pears & 17.191 \\
\hline 38 & Olives & 17.169 \\
\hline 39 & Cauliflower & 15.948 \\
\hline 40 & Rye & 14.851 \\
\hline 41 & Peaches and Nectarines & 14.788 \\
\hline 42 & Pineapples & 14.616 \\
\hline 43 & Garlic & 13.696 \\
\hline 44 & Lemons and Limes & 12.452 \\
\hline 45 & Spinach & 11.862 \\
\hline 46 & Peas, Dry & 10.248 \\
\hline 47 & Triticale & 10.245 \\
\hline 48 & Plums & 10.110 \\
\hline 49 & Green Corn (Maize) & 9.066 \\
\hline 50 & Taro (Coco Yam) & 8.939 \\
\hline 51 & Peas, Green & 8.914 \\
\hline 52 & Coffee, Green & 7.796 \\
\hline 53 & Palm Kernels & 7.503 \\
\hline 54 & Chick-Peas & 7.123 \\
\hline 55 & Dates & 6.749 \\
\hline 56 & Papayas & 6.342 \\
\hline 57 & Asparagus & 6.288 \\
\hline 58 & Beans, Green & 5.933 \\
\hline 59 & Okra & 4.940 \\
\hline 60 & Grapefruit and Pomelos & 4.697 \\
\hline 61 & Broad Beans, Dry & 4.033 \\
\hline 62 & Cow Peas, Dry & 3.722 \\
\hline 63 & Cocoa Beans & 3.257 \\
\hline 64 & Tea & 3.207 \\
\hline 65 & Strawberries & 3.199 \\
\hline 66 & Lentils & 3.093 \\
\hline 67 & Pigeon Peas & 3.053 \\
\hline
\end{tabular}




\begin{tabular}{|l|l|l|}
\hline 68 & Avocados & 3.040 \\
\hline 69 & Sesame Seed & 2.942 \\
\hline 70 & Apricots & 2.529 \\
\hline 71 & Pimento, Allspice & 2.482 \\
\hline 72 & Persimmons & 2.430 \\
\hline 73 & Linseed & 2.091 \\
\hline 74 & Cashew Nuts & 2.034 \\
\hline 75 & Buckwheat & 2.008 \\
\hline 76 & Cherries & 1.872 \\
\hline 77 & Almonds & 1.679 \\
\hline 78 & Cashewapple & 1.671 \\
\hline 79 & String Beans & 1.625 \\
\hline 80 & Lupins & 1.593 \\
\hline 81 & Walnuts & 1.446 \\
\hline 82 & Artichokes & 1.171 \\
\hline 83 & Figs & 1.087 \\
\hline 84 & Sour Cherries & 1.055 \\
\hline 85 & Broad Beans, Green & 1.052 \\
\hline
\end{tabular}




\section{Annex 3. Draft regional plant list based on the NETTOX food plant list.}

This regional food plant list for EU is the NETTOX food plant list from 1997 exempted the plants on the FAO list in Annex 2.

\begin{tabular}{|c|c|}
\hline English & Latin Names \\
\hline & Acer saccharum Marsh. \\
\hline Alligator pepper, guinea grains & Aframomum melegueta (Rosc.) K. Schum. \\
\hline Lesser galangal & Alpinia officinarum Hance \\
\hline Dill & Anethum graveolens L. \\
\hline Angelica & Angelica archangelica L. \\
\hline Cherimoya & Annona cherimola Mill. \\
\hline Pond apple & Annona glabra L. \\
\hline Soursop & Annona muricata $\mathrm{L}$. \\
\hline Bullock's heart & Annona reticulata $\mathrm{L}$. \\
\hline Noble chamomile, roman chamomile & Anthemis nobilis $\mathrm{L}$. \\
\hline Celery, celeriac & Apium graveolens L. \\
\hline Breadfruit, breadnut & Artocarpus communis J.R. et J.G.A. Foster \\
\hline Orache, garden orache & Atriplex hortensis L. \\
\hline Carambola, starfruit, caramba & Averrhoa carambola L. \\
\hline $\begin{array}{l}\text { Malabar spinach, Ceylon spinach, Indian } \\
\text { spinach }\end{array}$ & Basella alba L. \\
\hline European barberry & Berberis vulgaris $\mathrm{L}$. \\
\hline Chard, swiss chard, leaf beet, spinach beet & Beta vulgaris L. ssp. vulgaris var. cicla L.s.I. \\
\hline Borage & Borago officinalis $L$. \\
\hline Caraway & Carum carvi L. \\
\hline Coffee chicory & Cichorium intybus L. cv sativum \\
\hline Chinese cinnamon, Chinese cassia & Cinnamomum aromaticum Nees \\
\hline Batavia cinnamon, padang cassia & Cinnamomum burmanii BI. \\
\hline Ceylon cinnamon & Cinnamomum zeylandicum Schaeff. \\
\hline King mandarin tree & Citrus nobilis L. \\
\hline
\end{tabular}




\begin{tabular}{|c|c|}
\hline Spoon-wort, scurvy-grass & Cochlearia officinalis L. \\
\hline Coriander & Coriandrum sativum L. \\
\hline Cornelian cherry, cornel tree & Cornus mas L. \\
\hline Saffron, crocus & Crocus sativus L. \\
\hline Cumin, cummin & Cuminum cyminum L. \\
\hline $\begin{array}{l}\text { Common turmerio, Turmeric plant, Indian } \\
\text { saffron }\end{array}$ & Curcuma longa $L$. \\
\hline Zedoary & Curcuma zedoaria (Bergius) Rosc. \\
\hline $\begin{array}{l}\text { Sere-grass, lemongrass, West Indian lemon- } \\
\text { grass }\end{array}$ & Cymbopogon citratus (D.C.) Stapf. \\
\hline Cardoon & Cynara cardunculus \\
\hline Earth almond, yellow nutsedge & Cyperus esculentus \\
\hline $\begin{array}{l}\text { Water chestnut, matting reed, Chinese water } \\
\text { chestnut }\end{array}$ & Eleocharis dulcis (Burm. F.) Trinius ex Henschel \\
\hline Cardamon plant, cluster & Elettaria cardamomum (L.) Maton \\
\hline Rocket salad & Eruca sativa Mill. \\
\hline Surinam cherry, Brazil cherry & Eugenia uniflora L. \\
\hline Marumikunquat, round kunquat & Fortunella japonica (Thumb.) Swingle \\
\hline Kunquat, kunquat maruoni & Fortunella margarita (Lour) S. \\
\hline Wild strawberry & Fragaria vesca L. \\
\hline Scarlet strawberry, Virginia strawberry & Fragaria virginiana Mill. \\
\hline Liquorice & Glycyrrhiza glabra L. \\
\hline Cotton & Gossypium Sp. \\
\hline Topinambur, Jerusalem artichoke & Helianthus tuberosus $\mathrm{L}$. \\
\hline Roselle & Hibiscus sabdariffa L. \\
\hline Hyssop & Hyssopus officinalis L. \\
\hline Chinese anise, star anise tree & Illicium verum J.D. Hook \\
\hline Water Spinach & Ipomoea aquatica Forsk. \\
\hline Juniper & Juniperus communis L. \\
\hline Hyacinth bean, bonavist bean, lablab bean & Lablab purpureus (L.) Sweet \\
\hline Delicicus lactarius & Lactarius deliciosus Fr. \\
\hline Prickly lettuce & Lactuca serriola Turner L. \\
\hline Bottle gourd, calabash gourd & Lagenaria siceraria (Molina) Standl \\
\hline Chickling vetch, grasspea, kaasari & Lathyrus sativus L. \\
\hline Sweet bay, laurel, bay tree & Laurus nobilis L. \\
\hline Boletus & Leccinum scabrum Fr. \\
\hline Lovage, garden lovage & Levisticum officinale W. Koch \\
\hline
\end{tabular}




\begin{tabular}{|c|c|}
\hline Lemon verbena & Lippia triphylla (L'Hér.) Kuntze \\
\hline Acerola & Malpighia punicifolia L. \\
\hline Sapodilla, chicle & Manilkara zapota (L.) van Royen \\
\hline Balm, lemon balm & Melissa officinalis L. \\
\hline Spearmint & Mentha spicata L. \\
\hline Spearmint & Mentha spicata L. emend L. \\
\hline African cucumber, balsam epar, balsam apple & Momordica charantia L. \\
\hline Sweet basil, common basil & Ocimum basilicum L. \\
\hline Sweet majoram & Origanum majorana L. \\
\hline Wild marjoram, European oregano & Origanum vulgare $\mathrm{L}$. \\
\hline Guaraná & Paullina cupana H.B.K. \\
\hline Chinese lantern, winter cherry & Physalis alkekengi L. \\
\hline Cape gooseberry & Physalis peruviana $\mathrm{L}$. \\
\hline Allspice, Jamaica pepper & Pimenta dioica (L.) Merr. \\
\hline Anise & Pimpinella anisum L. \\
\hline Purslane & Portulaca oleracea L. ssp. sativa (Haw.) Celak. \\
\hline Cherry-plum tree, myrobalan-plum tree & Prunus cerasifera Ehrh. \\
\hline Japanese plum & Prunus salicina Lindl. \\
\hline Brasilian guava, Guinea guaava, guisaro & Psidium guineense \\
\hline Archil, orchil, angola weeb & Rorippa Nasturtium-aquaticum (L.) Hayeck. \\
\hline Dog rose, wild rose & Rosa canina L. \\
\hline Rosemary & Rosmarinus officinalis L. \\
\hline Cloudberry & Rubus chamaemorus L. \\
\hline Blackberry & Rubus fruticosus $L$. \\
\hline Raspberry & Rubus ideaus L. \\
\hline Sage & Salvia officinalis $L$. \\
\hline Brazilian peppertree & Schinus terebinthifolius Raddi \\
\hline Sesame, beniseed & Sesamum indicum L. \\
\hline Chinese artichoke, Japonese artichoke, & Stachys affinis Bunge \\
\hline Ringed boletus & Suillus luteus Fr. \\
\hline Clove tree & Syzygium aromaticum (L.) Merr. \& L.M. Perry \\
\hline Rose apple, jambos & Syzygium jambos (L.) Alston \\
\hline Dandelion & Taraxacum officinale Weber \\
\hline
\end{tabular}




\begin{tabular}{|l|l|}
\hline New Zealand spinach & Tetragonia tetragonioides (Pall.) Kuntze \\
\hline Wild thyme, creeping thyme & Thymus serpillum L. \\
\hline Garden thyme, common thyme & Thymus vulgaris L. \\
\hline Small-leaved lime tree, winter linden tree & Tilia cordata Mill. \\
\hline Large -leaved lime tree, summer linden & Tilia platophyllos Scop. \\
\hline Water chestnut, caltrops & Trapa natans L. \\
\hline African breadfruit & Treculia africana L. \\
\hline Fenugreek & Trigonella foenum-graecum L. \\
\hline Indian cress, garden nasturtium & Tropaeolum majus L. \\
\hline Truffle & Tuber melanosporum Vitt. \\
\hline Nettle, stinging nettle & Urtica dioica L. \\
\hline & Vaccinium uliginosum L. \\
\hline Cowberry & Vaccinium vitis-idaea L. \\
\hline Cornsalad, lamb's lettuce & Valerianella locusta (L.) Laterrade \\
\hline Adzuki bean & Vigna angularis (Willd.) Ohwi et Ohashi \\
\hline Black gram & Vigna mungo (L.) Hepper \\
\hline Chinese date & Ziziphus ziziphus L. Meikle \\
\hline
\end{tabular}

